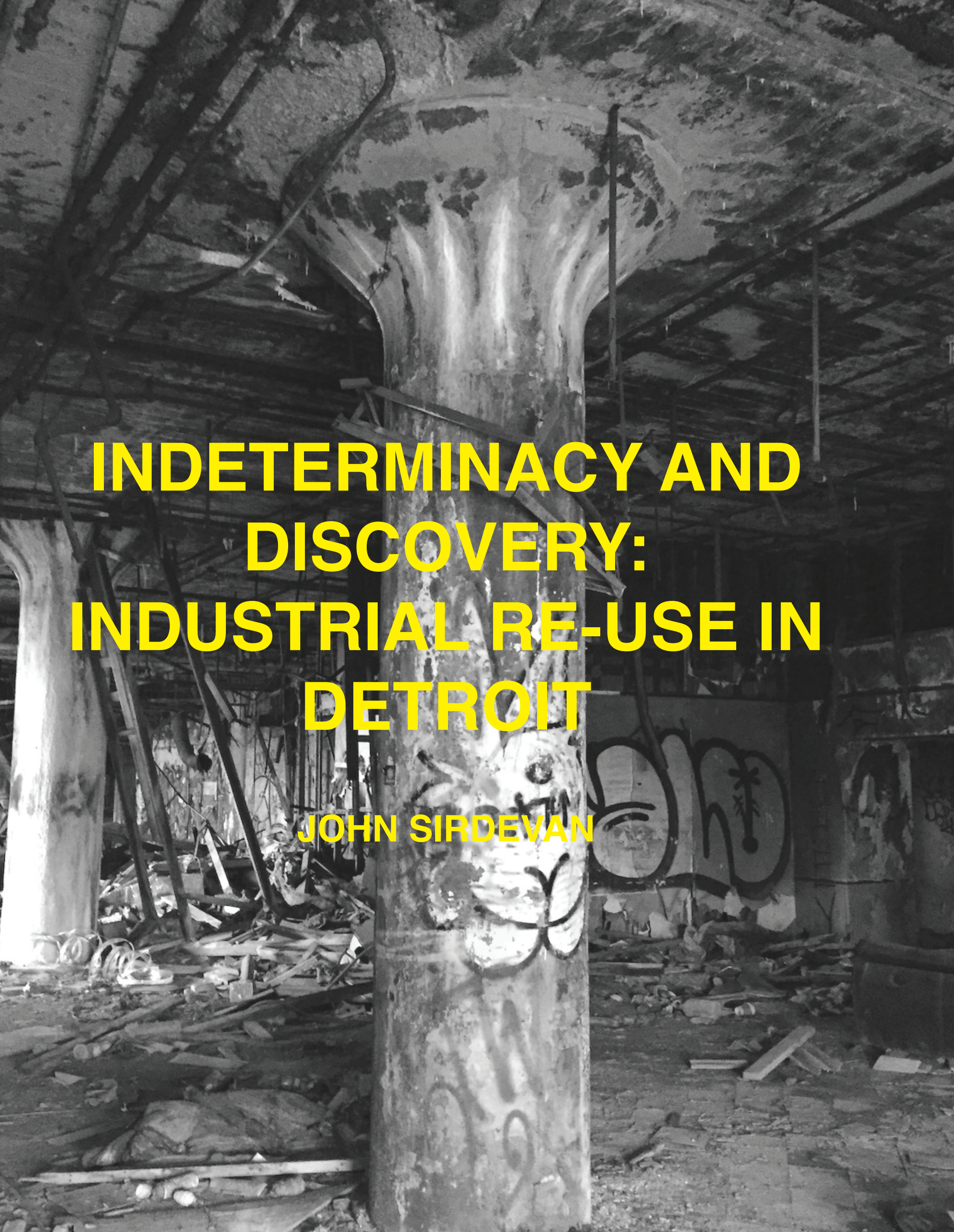





\title{
Indeterminacy and Discovery: Industrial Re-Use in Detroit
}

\author{
By \\ John Sirdevan \\ Bachelor of Architectural Science, Ryerson University, Toronto, 2015 \\ A thesis \\ presented to Ryerson University \\ in partial fulfillment of the \\ requirements for the degree of \\ Master of Architecture \\ in the Program of \\ Architecture \\ Toronto, Ontario, Canada, 2019 \\ (C) John Sirdevan 2019
}




\section{Author's Declaration}

I hereby declare that I am the sole author of this thesis. This is a true copy of the thesis, including any required final revisions, as accepted by my examiners.

I authorize Ryerson University to lend this thesis to other institutions or individuals for the purpose of scholarly research.

I further authorize Ryerson University to reproduce this thesis by photocopying or by other means, in total or in part, at the request of other institutions or individuals for the purpose of scholarly research. I understand that my thesis may be made electronically available to the public. 

Indeterminacy and Discovery:

Industrial Re-Use in Detroit

John Sirdevan

Master of Architecture

Ryerson University, 2019

\section{Abstract}

The displacement and lack of affordable space that occurs as a consequence of gentrification, ultimately undermines and threatens the rich cultural capital generated by displaced and marginalized communities. An adaptive reuse strategy in which an indeterminate, heterogeneous spatial composition is employed, can stimulate creative and alternative counter cultural activity, which contributes positively to the cultural, educational, and economic fabric of the site's adjacent communities. 


\section{Acknowledgements}

The completion of this work is indebted to the following:

Dr. June Komisar (thesis supervisor)

Scott S $\square$ rli (second reader) and Dr. Leila Farah (program representative)

My MArch colleagues

My family 
"Because architecture promotes a knowledge about cities and space, it is also the site of imagination, of experience, of critical re-examining. This phenomenal and intellectual experience of architecture, showing how people encounter architecture in conditions of, for example, danger, exhilaration, anonymity and sexual freedom, has been successfully shown for cities such as Paris London and Berlin. Such works... also help challenge the universalism of experience and to problematize the identity of the subject, while simultaneously denaturalizing capitalism and it's politics of space"

- lain Borden, 2001 

Table of Contents

Author's Declaration

Abstract

Acknowledgements

Dedication

Table of Contents

List of Figures

List of Appendices

Introduction

Chapter 1 - Fordism and Detroit's Industrial Architecture

1.1 Albert Khan: The Architect of Fordism and Industrial Detroit

1.2 Order, Determinism and Modernism

1.3 The Machine for Living

1.4 The Re-appropriation of Detroit's Lafayette Park

Chapter 2 - The Decline of Industrial Manufacturing

2.1 The Decline of Industrial Detroit

2.2 Cultural Activity in Detroit's Inner City

2.3 Detroit's Abandoned Industrial Infrastructure

\section{Chapter 3 - Precedent Case Studies}

3.1 Case Study Analyses
Artscape Wychwood Barns
Outdoor Adventure Center
Russell Industrial Center
Streetmekka Esbjerg

Chapter 4 - Creative Space Architecture

4.1 Slack space, Indeterminacy, User Determinism

4.2 Temporal Disruption: The Aesthetics of Ruins

4.3 Abandoned Space Appropriation

4.4 Psychogeography as Design Strategy

4.4 Design Research

Chapter 5 - Development without Gentrification

5.1 NGO's, Land Banks, Community Trusts etc. 
Chapter 6 - Site: Albert Khan's Fisher Body \#21

6.1 Site History

6.2 Site Context

6.3 Building Information

Chapter 7 - Building Strategy and Design

7.1 Project Delivery Phases

7.2 Program

7.3 Retrofit Strategy

7.4 Architectural Design Strategy

7.5 Design Exploration

\section{Chapter 8 - Conclusion}

\section{Appendices}

\section{Bibliography}




\section{List of Figures}

Figure 1.1 Detroit Aerial Photograph. Retrieved https://www.google.com/maps/place/Detroit,+MI

Figure 1.2 Packard Plant no. 10. Retrieved from: https://www.loc.gov/pictures/item/det1994018916/ $\mathrm{PP} /$

Figure 1.3 Ford Model T. Retrieved from: https://collections.lib.utah.edu/details?id=525524

Figure 1.4 Ford Highland Park Plant. Retrieved from: https://www.hemmings.com/blog/2013/07/19/ highland-park-plant-birthplace-of-fords-assembly-line-eyed-for-preservation/

Figure 1.5 Highland Park Assembly Line. Retrieved from: https://www.nydailynews.com/autos/fordassembly-line-turns-100-changed-society-article-1.1478331

Figure 1.6 Highland Park Assembly Line. Retrieved from: https://rasoja.files.wordpress.com/2013/03/ highland-park-production.jpg

Figure 1.7 River Rouge. Retrieved from: https://clas.berkeley.edu/research/art-diego-and-frida-arttranscends-borders

Figure 1.8 Le Corbusier Pessac. Retrieved from: https://agingmodernism.wordpress.com/2010/08/20/ pessac-stifled-alterations/

Figure 1.9 Lafayette Park High-rise Towers. Retrieved From: http://www.corinevermeulen.com/project/ thanks-for-the-view-mr-mies-detroit-2009

Figure 1.10 Lafayette Park High-rise Resident. http://www.corinevermeulen.com/project/thanks-forthe-view-mr-mies-detroit-2009

Figure 2.1 Detroit Race Riots 1967. Retrieved from: https://blackpast.org/aah/detroit-race-riot-1967

Figure 2.2 Detroit Suburbs 1960's. Retrieved from: http://www.detroits-great-rebellion.com/The-Roadto-67-.html

Figure 2.3 Diego Rivera Detroit. Retrieved from: https://en.wikipedia.org/wiki/Detroit_Industry_Murals

Figure 2.4 Diana Ross and the Supremes. Retrieved from: https://www.morrisonhotelgallery.com/photographs/Fg4nMU/Diana-Ross-and-The-Supremes-Hitsville-USA-Detroit-MI-1965

Figure 2.5 The Spirit of Detroit. Retrieved from: https://www.detroitnews.com/story/news/local/detroitcity/2018/05/08/spirit-detroit-undergoes-routine-maintenance/589976002/

Figure 2.6 The Heidelberg Project. Retrieved from: http://juliaemilyemile.tumblr.com/ post/76545491441/the-heidelberg-project-is-the-vision-of-tyree 
Figure 2.7 Abandoned Packard Plant. Retrieved from: https://en.wikipedia.org/wiki/Packard_Automotive_Plant\#/media/File:Abandoned_Packard_Automobile_Factory_Detroit_200.jpg

Figure 2.8 Abandoned Connor Creek Power Plant. Retrieved from: https://detroit.curbed. com/2018/5/29/17396228/development-notes-conners-creek-shapero-hall-palm-trees-detroit

Figure 3.1 Artscape Wychwood Barns. Photo by author.

Figure 3.2 Artscape Wychwood Barns. Photo by author.

Figure 3.2 Artscape Wychwood Barns. Photo by author.

Figure 3.3 Detroit Adventure Center. Retrieved from: retrieved from: https://www.michigan.gov/oac/

Figure 3.4 Detroit Adventure Center. Retrieved from: retrieved from: https://www.michigan.gov/oac/

Figure 3.5 Russell Industrial Center. Retrieved from: https://www.virgin.com/entrepreneur/inside-detroit-the-russell-industrial-center

Figure 3.6 Russell Industrial Center. Retrieved from: https://www.virgin.com/entrepreneur/inside-detroit-the-russell-industrial-center

Figure 3.7 Streetmekka Esbjerg. Retrieved from: https://www.effekt.dk/gse/

Figure 3.8 Streetmekka Esbjerg. Retrieved from: https://www.effekt.dk/gse/

Figure 4.1 Parc de la Villette Follies. Retrieved from: https://www.moma.org/collection/works/625

Figure 4.2 Tacheles, Berlin. Retrieved from: https://www.theguardian.com/artanddesign/ jonathanjonesblog+profile/jonathanjones?page $=37$

Figure 4.3 The Naked City. Retrieved from: https://weegeeweegeeweegee.net/2014/10/30/not-thenaked-city-5/

Figure 4.4 Model of New Babylon. Retrieved from: https://ravenkop.com/ravenkop-deelt-inzichtenkromhouthal/constant-new-babylon/

Figure 4.5 Deconstruction Exploration 1. Image by Author

Figure 4.6 Deconstruction Exploration 2. Image by Author

Figure 4.7 Deconstruction Exploration 3. Image by Author

Figure 4.8 Deconstruction Exploration 1. Image by Author

Figure 6.1 Fisher Body \#21, Retrieved from: https://thisiscourtney.com/photos/fisher-body-plant-21/ 
Figure 6.2 1921 Fire Map. Fisher Body 21. Retrieved from: https://www.loc.gov/item/sanborn03985_028/

Figure 6.3 Historic aerial photograph of Fisher Body \#21 in the 1920's. Retrieved from: https://substreet.org/fisher-body/

Figure 6.4 Site Aerial Diagram. Image by Author

Figure 6.5 Site Aerial Diagram. Image by Author

Fig. 6.6 Vacant and Occupied North End Residential Properties. Retrieved from: https://taubmancollege.umich.edu/sites/default/files/files/mup/capstones/Historys_Future_North_End.pdf

Fig. 6.7 Condition of North End Residential Properties. Rertieved from: https://taubmancollege.umich. edu/sites/default/files/files/mup/capstones/Historys_Future_North_End.pdf

Fig. 6.8 Context Plan. Image by Author

Fig. 6.9 Fisher Body \#21 Existing Elevations. Image by Author

Fig. 6.10 Fisher Body \#21 Existing Plan and Section. Image by Author

Fig. 6.11 Fisher Body \#21. Photo by Author

Fig. 6.12 Fisher Body \#21. Photo by Author

Fig. 6.13 Fisher Body \#21. Photo by Author

Fig. 6.14 Fisher Body \#21. Photo by Author

Fig. 6.15 Fisher Body \#21. Photo by Author

Fig. 6.16 Fisher Body \#21. Photo by Author

Fig. 7.1 Top Floor Assembly Line. Retrieved from: http://www.detroiturbex.com/content/industry/fisher/ index.html

Fig. 7.2 Ruinous Aesthetic. Retrieved from: https://mapio.net/s/17232245/

Fig. 7.3 Damaged Wooden Structure in Rear. Image by Author

Fig. 7.4 Exploded Axonometric Diagram. Image by Author

Fig. 7.5 Proposed Site Plan. Image by Author

Fig. 7.6 Proposed Site Axonometric. Image by Author 
Fig. 7.6 Proposed First Floor Plan. Image by Author

Fig. 7.7 Proposed Second Floor Plan. Image by Author

Fig. 7.8 Proposed Third Floor Plan. Image by Author

Fig. 7.9 Proposed Fourth Floor Plan. Image by Author

Fig. 7.10 Proposed Fifth Floor Plan. Image by Author

Fig. 7.11 Proposed North and South Elevation. Image by Author

Fig. 7.12 Proposed East and West Elevation. Image by Author

Fig. 7.13 Proposed Section AA and Section BB. Image by Author

Fig. 7.14 Rendered South Elevation. Image by Author

Fig. 7.15 Piquette Avenue Sectional Perspective. Image by Author

Fig. 7.16 Perspective Approach from South East. Image by Author

Fig. 7.17 Perspective Looking West down Piquette Avenue. Image by Author

Fig. 7.18 Interior Perspective 1. Image by Author

Fig. 7.19 Interior Perspective 2. Image by Author

Fig. 7.20 Interior Perspective 3. Image by Author

Fig. 7.21 Interior Perspective 4. Image by Author

Fig. 7.22 Interior Perspective 5. Image by Author

Fig. 8.1 Fisher Body Die Building Plans. Image received from Kahn and Associates.

Fig. 8.2 Fisher Body Die Building Elevations. Image received from Kahn and Associates.

Fig. 8.3 Fisher Body Die Building Elevations. Image received from Kahn and Associates. 
Fig. 8.4 Fisher Body Die Building Details. Image received from Kahn and Associates.

Fig. 8.5 Design Research. Image by Author

Fig. 8.6 Design Research. Image by Author

Fig. 8.7 Design Research. Image by Author

Fig. 8.8 Design Research. Image by Author 



\section{Introduction}

In the United States, The decline of industrial manufacturing and the growth of the suburbs in the 1950's and 60's brought about the decline of inner-cities, a decline which was manifested in population decrease, middle class suburban flight, growth of inner-city ghettos, real estate value decline, a rise in poverty, and in the dilapidation of the physical environment. The decline of these cities ultimately resulted in social unrest, protest, and violent racially motivated riots in the late 1960's. By the end of the 1970's many American inner cities were in crisis; a consequence of poverty and decay.

It was within this context that several sub-cultural movements emerged. The former heavily industrial cities of the 1970's (most notably, New York City) became epicenters of subcultural activity, as new movements in the music and art worlds emerged amongst the industrial decay and 20th century planning issues.

By the late 1980's, however, amid a renewed interest in city dwelling and the emergence of the affluent creative class; that being those that work in the knowledge economy as opposed to the industrial economy, cities such as New York and San Francisco became epicenters of the emerging 'creative' economy, displacing many of the people in marginalized and counter cultural communities that called these cities home.

This is a process that continues today in many cities across North America and the world.

The city of Detroit, however, a city once known as the world epicenter of the automotive industry, and a city that had once teemed with industrial might and ingenuity, never fully recovered from de-industrialization. The city has continued to shrink in population, falling from nearly 2 million people in the 1950's, to about 700,000 as of the 2010 consensus.

There are many reasons for Detroit's continued decline including waning industry, racial tensions, corrupt leadership, lack of public infrastructure, and systemic poverty. Nevertheless, amid the decay and blight, the spirit of the city lived on, giving rise to many important movements in music, arts and culture.

In recent years, investment has begun to return the city of Detroit, as private stakeholders see opportunity in cheap real estate and an emerging knowledge based economy.

While many of these improvements are welcome additions to the city, it is imperative to the healthy growth of Detroit that developers and property value speculators show restraint in what should be seen as a delicate renewal process. 
Identified amongst the most vulnerable members of displaced communities are the youth and young adult populations, who are lacking in infrastructure in which to play, learn, and create.

As identified by the Detroit Future City organization and the municipal government of Detroit, underused or unoccupied industrial architecture and informal public space in the city of Detroit provides a scale and ubiquity, which is ideally positioned for re-use or re-appropriation as buildings and spaces where imaginative, alternative, and valuable cultural practices can be fostered and stimulated.

This thesis will explore an approach to adaptive reuse and re-appropriation in which such a space is embraced and preserved as a place of cultural production.

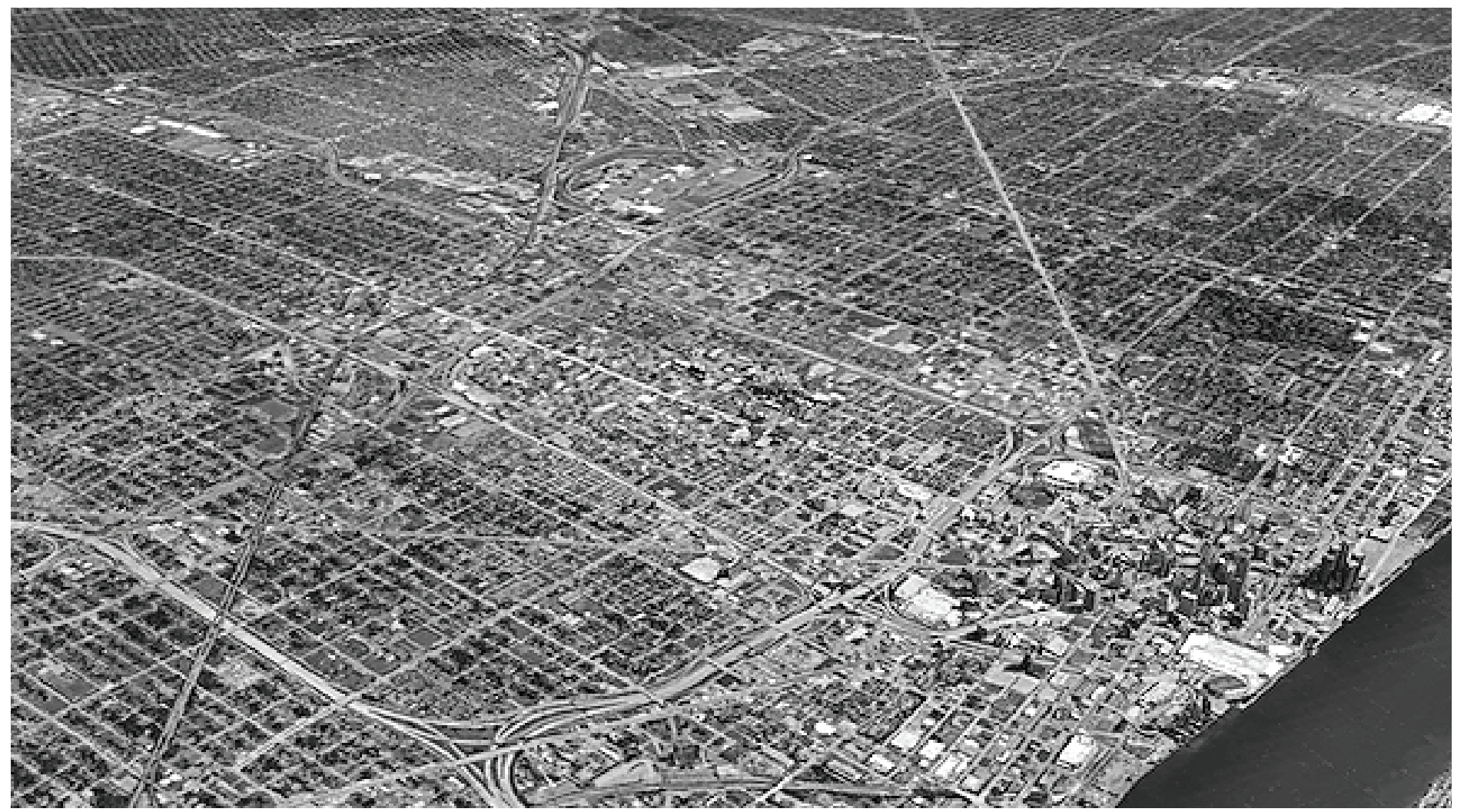

Figure 1.1 Detroit Aerial Photograph 


\section{Chapter 1 - Fordism and Detroit's Industrial Architecture}

\subsection{Albert Khan: The Architect of Fordism and Industrial Detroit}

Innovation in industrial processes in the late 19th century led to the development of materials such as high strength steel and plastics. Mass Industrial processes of these materials meant that their purchase prices were lowered significantly, and were thus widely available for a variety of uses. Further, steel fabrication was made easier and more accessible through the development of electric welding and stamped steel parts.

The emergence of mass industrial production and the related rise in consumption habits of the general public meant that a new type of building typology, the factory, emerged. For many architects in the early 20th century, factories became important symbols of technological advancements, and were of "great importance to the young century" (Hildebrand, 1974, p. 2). Albert Kahn, a German born architect who established his practice in Detroit in 1896 (Hildebrand, 1974, p. 3), was uniquely poised to take on the challenges of this emerging building typology.

Smaller residential buildings, nursing homes, and single-family homes, all designed in conventional styles, mostly typified Kahn's early work in that period. In 1902, Albert's brother Julius, who had served as a civil engineer in the US military (Hlidebrand, 1974, p. 26) joined the firm as a structural engineer. Early in his career at Kahn associates, Julius Kahn invented "a bar truss system for reinforced concrete" (Gartman, 2009, p.46), which allowed for much longer structural spans than previously possible, thus revolutionizing factory design. This system, paired with Detroit's emerging auto industry, meant that Khan would become established as Detroit's most prolific industrial era architect.

Khan's first factory using this system was Packard Plant no. 10 (Gartman, 2009, p.46) (Fig. 1.1), completed in 1905. The long span truss system "reduced significantly the frequency of interior columns" (Hildebrand, 1974, p.31), which increased workflow and as a result, yielded greater productivity. The success of the Packard Plant resulted in Kahn being chosen by emerging auto maker Henry Ford to design his new auto manufacturing facility. In 1908, Ford announced the "Model T" (Fig. 1.2) a car that would revolutionize the automobile industry due to Ford's innovation in mass manufacturing known as the assembly line. The assembly line, in its utilization of unskilled, and thus cheap, labor, meant that the Model T; "had to be standardized in to one unflinching type" (Gartman, 2009, p.46).

Ford's Highland Park Plant (Fig. 1.3), completed in 1910, was designed by Khan to accommodate Ford's innovative manufacturing process (Fig. 1.4), in that it would "consolidate all operations under one roof and all major operations on one floor" (Hildebrand, 1974, p.45). The open unobstructed interior space accommodated the close packing of workers and machines, allowing for the free flow of work between them. This new method of manufacturing would establish a production output the likes of which industrial world had not previously seen. 
In his book 'From Auto's to Architecture', author David Gartman presents a scathing critique of Khan's early industrial work: "What he achieved.. was nothing less than the completion of the rationalization of space begun by the Chicago School. Here architecture became nothing more than a means to an external end, an instrument for the efficient production of cars and ultimately profit, with no regard whatsoever for aesthetics, the human condition or the natural landscape." (Gartman, 2009, p.47). The industrial architecture of the early 20th century, much like the Ford assembly line (and the proceeding modernist era) were conceived of as deterministic catalysts in the perpetual desire for order, functionality, efficiency and profit.

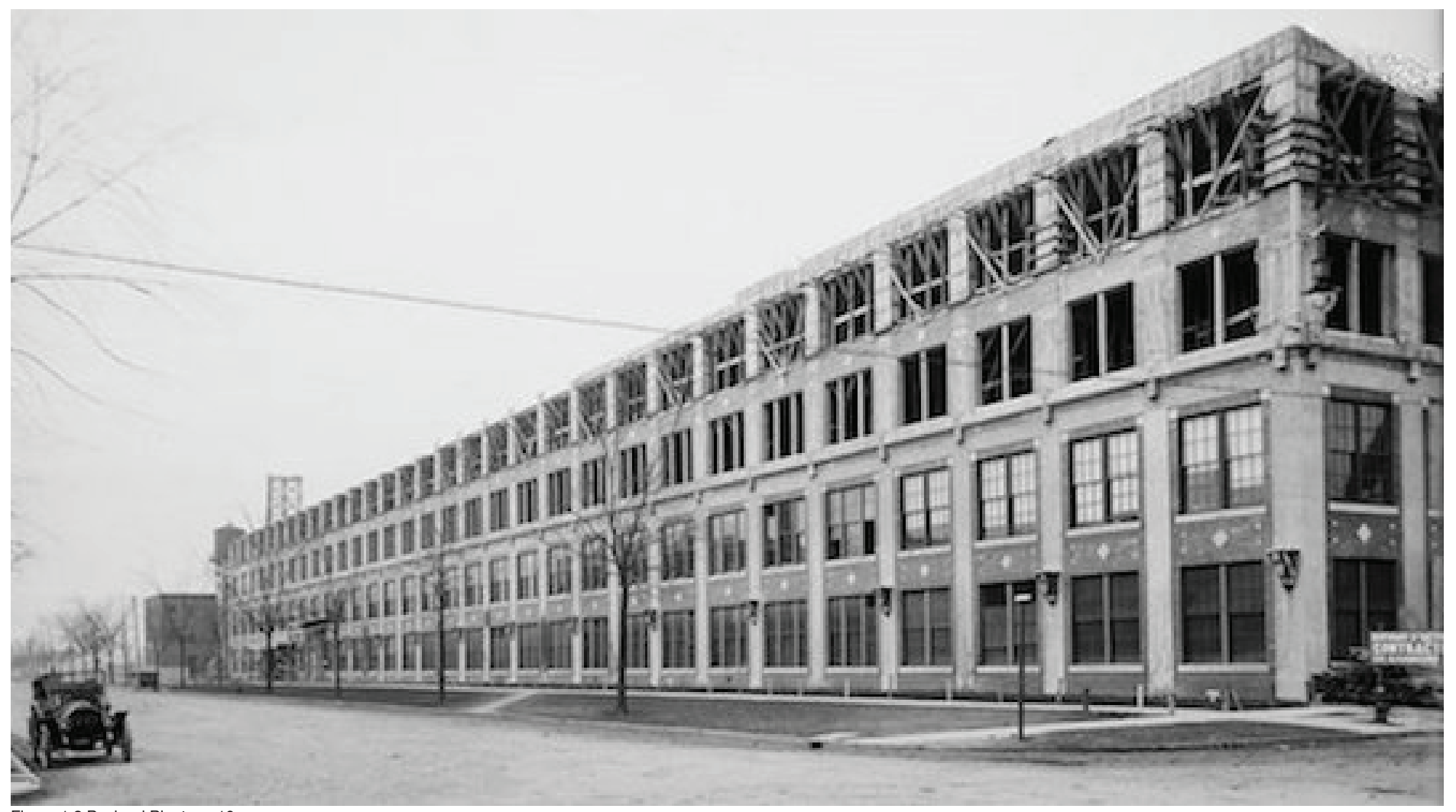

Figure 1.2 Packard Plant no. 10 

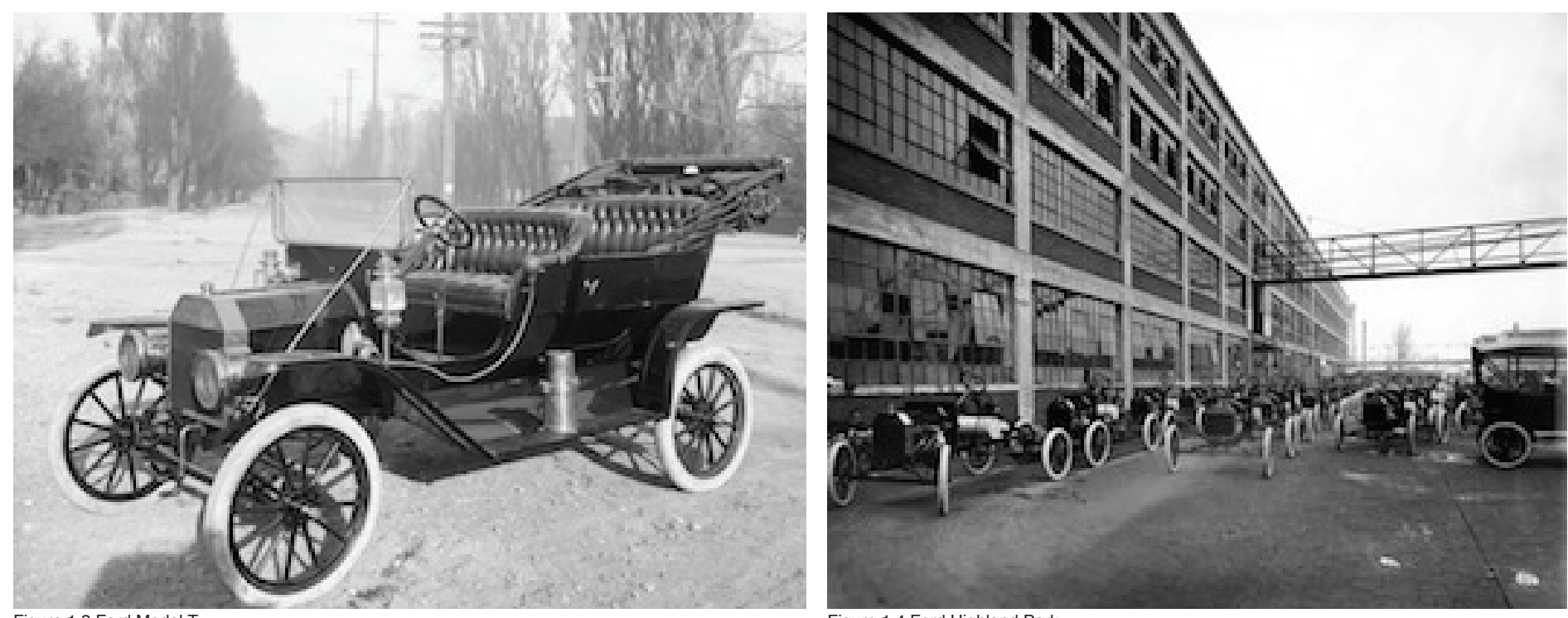

Figure 1.3 Ford Model T

Figure 1.4 Ford Highland Park

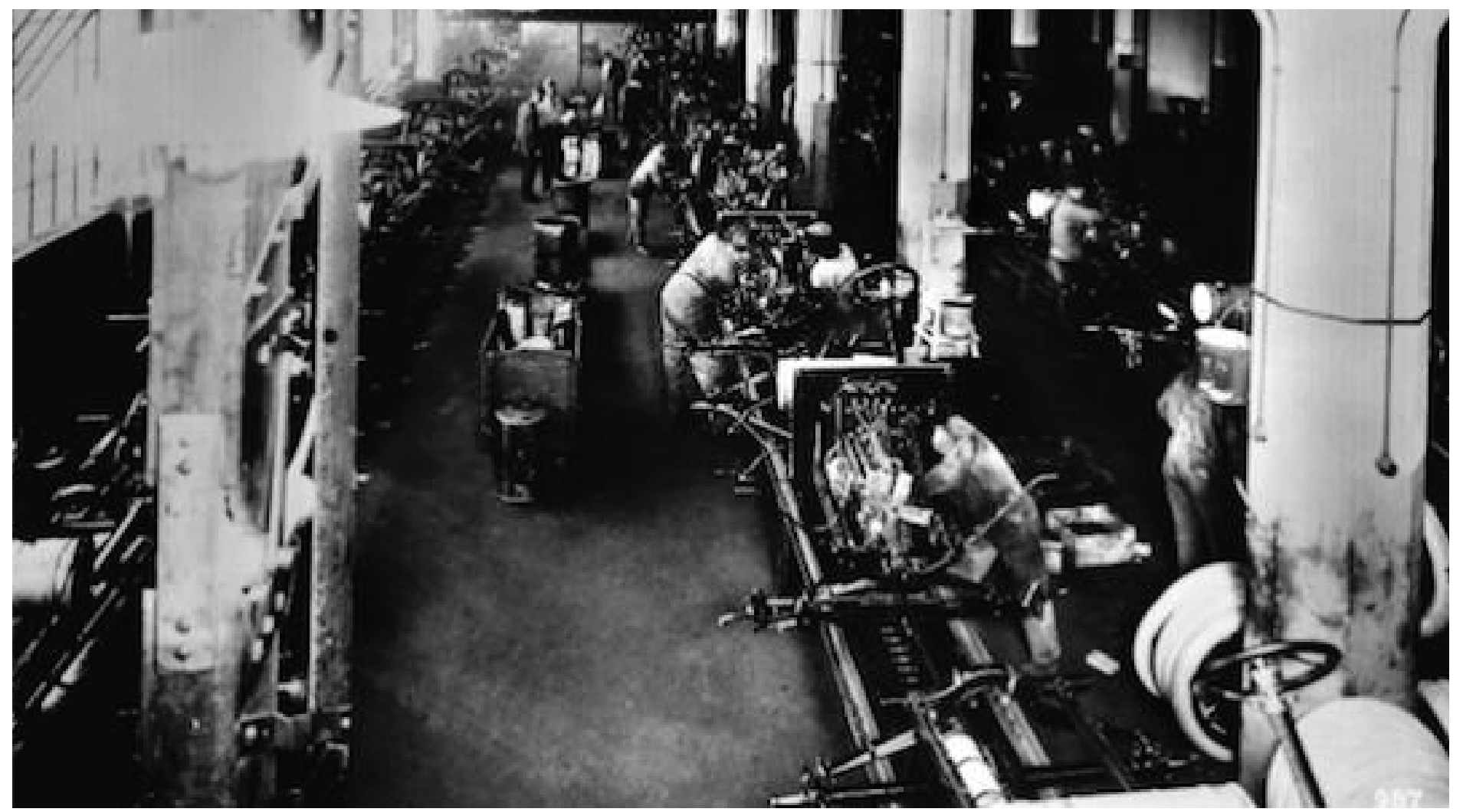

Figure 1.5 Highland Park Assembly Line 


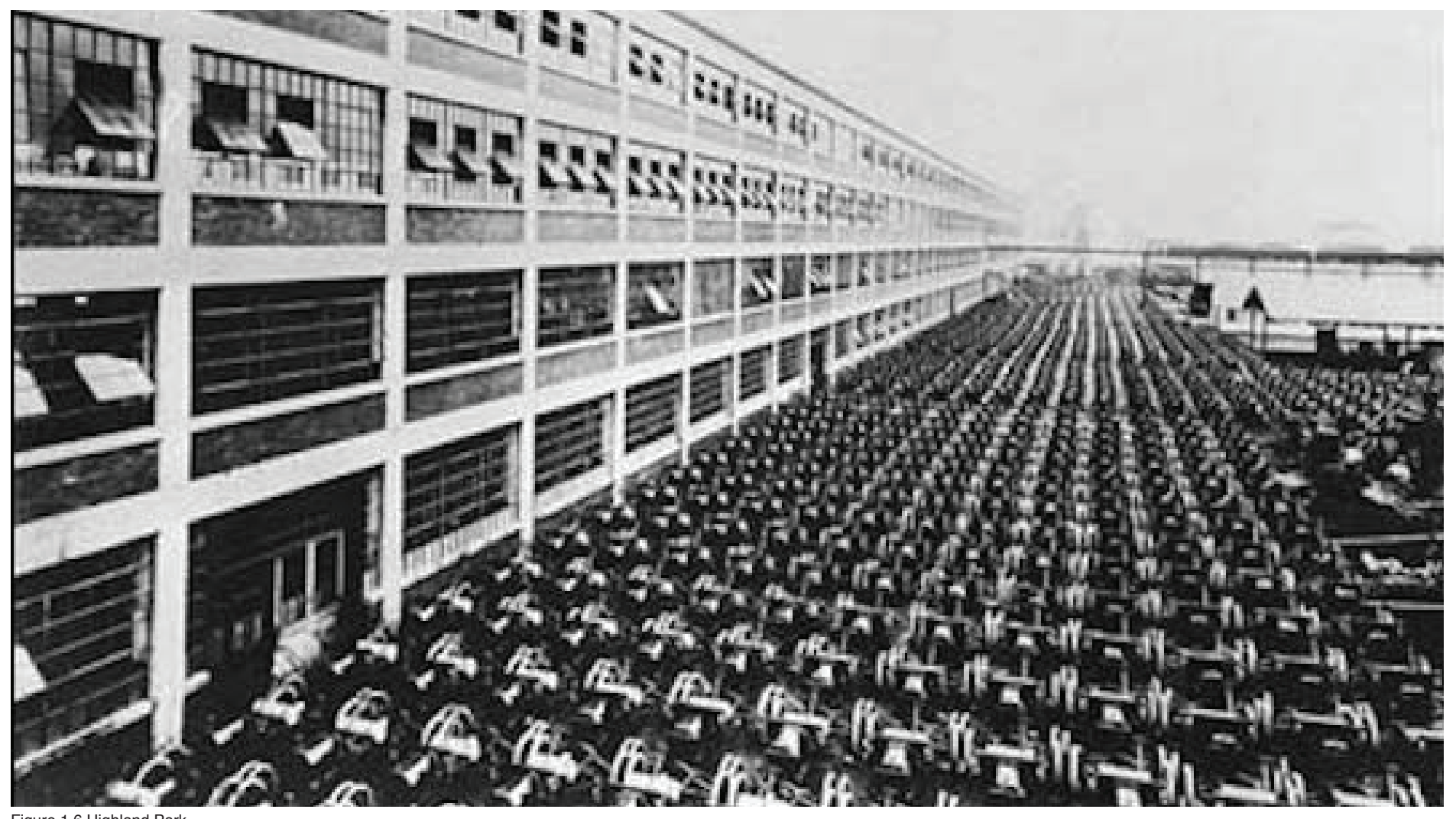

Figure 1.6 Highland Park

Through the architecture of Highland Park, Rouge River, and many others, Albert Khan sought to achieve these same objectives. As a result, Kahn was instrumental in the way the city of Detroit evolved over the course of the 20th century, both in its physical and ideological form. There are few cities in the world where these ideas and their physical manifestation are seen in greater abundance than in the city of Detroit.

The outcome of Khan's and Ford's achievements, however, stands in stark opposition to their initial objectives. Over the course of the coming century, Detroit would experience a decline unrivaled by that of any other American industrial city. This is, at least partly, due to the unchecked, deterministic desire for efficiency and profit, and unwillingness to consider the complexity of the human condition. 


\subsection{Order, Determinism, and Modernism}

"As we shall see with architecture, as with any project of the modern age, the more one attempts to eliminate the other of the order, the more it comes back to haunt one. Weeds always come back. The whiter the wall, the quicker it succumbs to dirt. In their pursuit of an idea (and an ideal) of order, architects have to operate in a state of permanent denial of the residual power of the other of order." (Till, 2009, p.34).

Following the success of the assembly line facility at Highland Park, Henry Ford, with Khan as the architect, built the massive Rouge River production facility in Dearborn, Michigan just south of Detroit. The Rouge River facility, once completed in the early 1920's, encompassed 2000 acres of land along the Rouge River, and at its peak employed 100,000 people. The demand for cars amid a booming 1920's post World War One economy, paired with Fords assembly line production method, meant that the Ford industrial model would result in tremendous growth for the company and an egregious accumulation of wealth; not only for Ford but also the American auto industry en mass.

However, while Ford and other modern industrialists amassed fortunes, the conditions inside the once pristine, modern factories continued to decline, as they became increasingly congested, dirty, and hazardous. As a result, workers inside Ford's factories began to organize and protest the poor working conditions. The unrest eventually culminated in a 1914 attempt by Ford assembly line workers to form a labor union.

Ford refused to concede to workers demands however, and instead offered the assembly line laborers a 'five dollar day' wage program, which: "doubled the average daily wage of most workers" (Gartman, 2009, p.50). Ford's wage program proved successful, appeasing owners, trade unionists, and laborers alike. As a result, unskilled laborers in Ford's factories now made a middle class wage; changing the social dynamic in middle class neighborhoods, and establishing an even greater emphasis on consumer consumption. In fact, it is believe by many that Ford's plan to increase wages was motivated by the idea that they could then afford to purchase his cars. Nevertheless, many of Fords factory workers embraced their new social status. 
Still yet, with no union to lobby for improvements, working conditions within the factories continued to grow worse. As a result, workers sought refuge from the factories' poor working conditions in their homes and domestic lives. Ironically however, the modernist architects in the 20th century sought to produce domestic buildings that would aspire to achieve the same level of ordered functionalism in domestic life. In doing so, these new domestic buildings reflected the damage done to people within the dehumanized, tyrannical mass production process, undermining their own human instincts to instead inspire a homogenous, functional, and efficient world of home consumption and domestic production.

As Gartman (2009) states, "Workers found it difficult to find peace and comfort in domestic surroundings disrupted buy the ugliness of the instrumental rationality of work" (p.51). 
Modern architecture, in the domestic realm, has sought to achieve the same type of determinist functionalism, rationalism, and efficiency that the commercial and industrial architecture of the early 20th century cynically achieved. Le Corbusier, in his seminal 1924 book 'Towards an Architecture", expressed that a home ought to be "a machine for living in" (Corbusier, 87) and that "industry, invading like a river that rolls into its destiny, brings us new tools adapted to this new era animated by a new spirit" (Corbusier, 1924, p.88). It was Corbusier's 1926 housing project “Quartiers Moderns Fruges” (Fig. 1.7) at Pessac, France that aspired to put this manifesto into practice. At Pessac, Corbusier wanted to provide inhabitants with an empty container; a proverbial 'blank canvas', onto which they could insert themselves and their lives. Corbusier sought to achieve this by creating a functional system based on new technological advancements in concrete, steel, and glass, to build predetermined, homogenous and cube like structures that would compliment each other through their spatial configuration.

By doing so, Corbusier felt that he could achieve a modern domestic ideal whereby occupants could insert themselves into their 'containers', occupying them and passively engaging in their efficiency. By doing so, the architecture itself would make their daily lives more functional and ordered.

In reality, what happened was that the occupants of Quartiers Modern Fruges converted their 'machines for living' into their highly personalized homes. Henry Lebfevre is quoted: "in Pessac Le Corbusier produced a kind of architecture that lent itself to conversion and sculptural ornamentation... and what did the occupants add? Their needs" (Boudon, 1969, p.1).

In Philip Boudon's book "Lived-in Architecture", he writes of Pessac: "not only have the colors disappeared in the vast majority of cases, but the 'wide windows' have been made narrower, the patios have been enclosed, many of the original terraces have been roofed over, the empty spaces beneath the stilts have been blocked off.. much to the detriment of the architecture, helps to create a general impression of dilapidation... There has also been a real conflict between what the architect intended and what the occupants wanted" (Boudon, 1969, p.2).

It is here that parallels can be drawn between architects such as Corbusier and Kahn, and industrialists like Ford. To an extent, all three were visionary idealists who lived by ideals which aspired to improve daily life, increase productivity, and inspire efficiency.

Top-down deterministic functionalism, the desire for order, and the creation of static homogenous architecture to achieve these goals is, regardless of circumstance, a failed proposition. The remains of this failure, however, can provide a lesson about the needs and desires of the user. While production, efficiency, and functionality were achieved, humanity ultimately was not. The humanity lies in the reappropriation and re-adaptation of the remainders of a failed proposition. 
"People are not abstractions. They do not submit to the reason of functionalism; they have emotions, lives, accidents, and politics. The space of abstraction cannot accommodate the spatiality of being (or) the sociality of being.. the other of order can never be ridded. Waste, dirt, contingency all come back to haunt the unattainable illusions of the modern project." (Till, 2009, p.36).

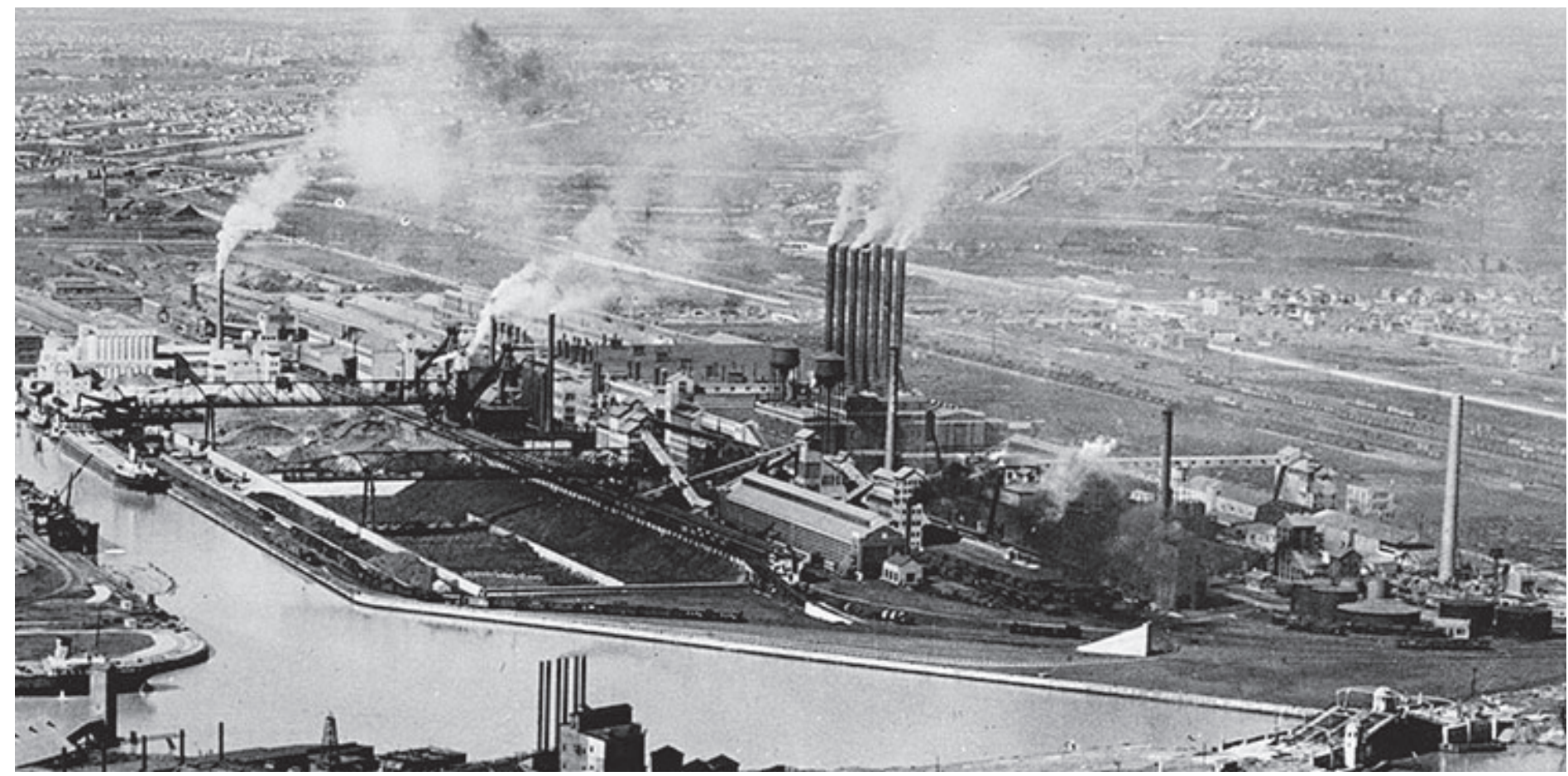

Figure 1.7 Rouge River
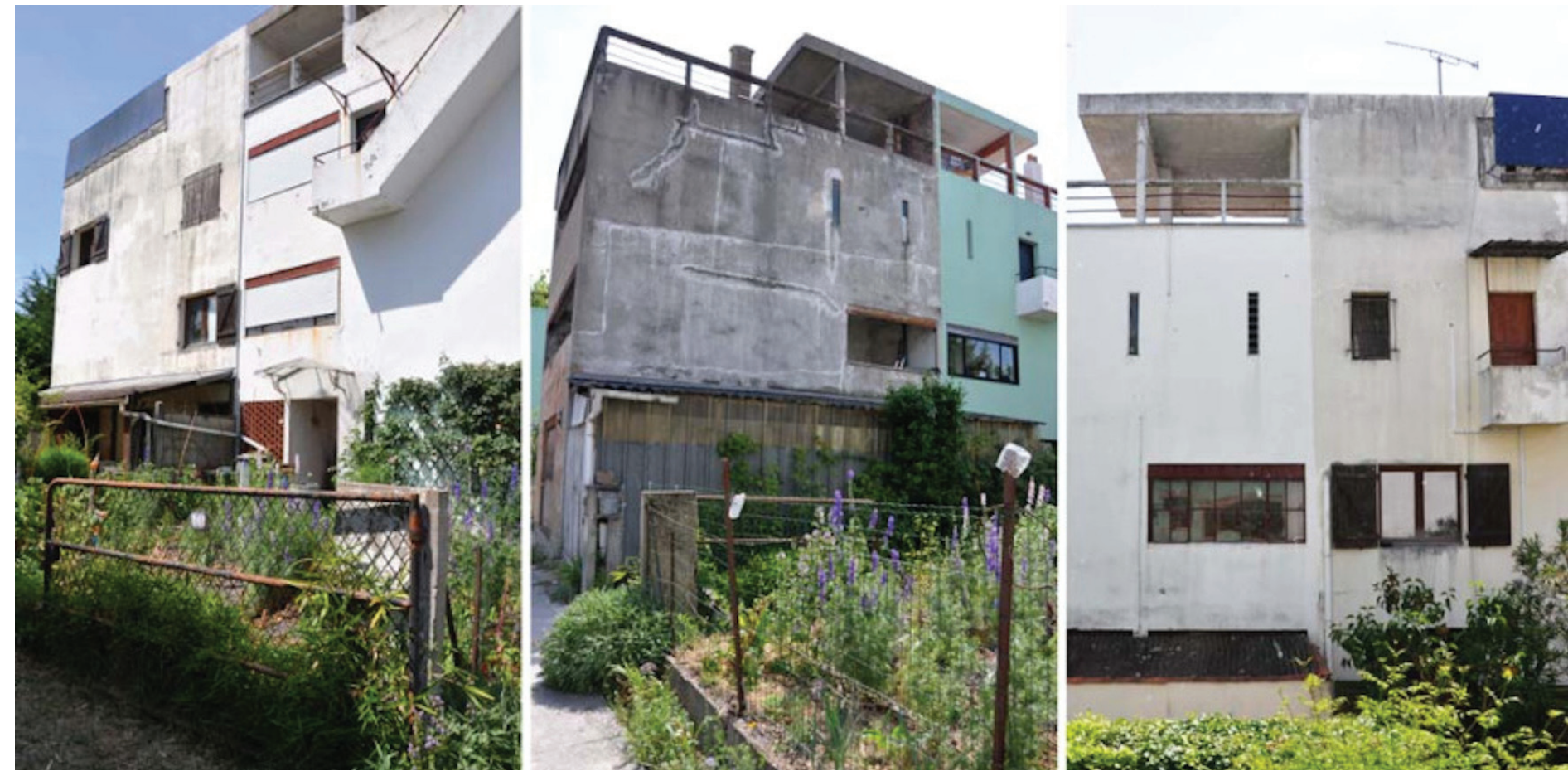

Figure 1.8 Le Corbusier's Pessac 


\subsection{The Re-appropriation of Detroit's Lafayette Park}

Modern domestic architecture also experienced a rise in Detroit in the early-to-mid 20th century. This is perhaps most significantly represented by the large downtown residential development Lafayette Park (Fig. 1.8), designed by famed modernist architect Mies Van Der Rohe and completed in 1962. As with Albert Kahn's work in Ford's factories, Mies sought out to achieve a clean, efficient, and safe community by establishing order and functionality in the architecture and landscape of the development. As New York Times journalist Miller identifies, Lafayette Park was "built on the site of Detroit's Black Bottom, the heart of the city's growing African-American population that was razed in the early 1950s, one of countless examples of minority communities routinely targeted by urban renewal projects receiving vast sums of government money for "slum clearance." (2018). Lafayette Park consists of three high-rise towers, 24 single-story courthouses, and 162 two-story town houses. It was achieved with the help of two other world renowned designers; Ludwig Hilbersheimer as urban planner, and Alfred Caldwell as landscape designer.

However, relative to other failed urban renewal residential developments, such as Pruitt Igoe in St. Louis, Lafayette Park has largely been deemed a historical success. The modernist development not only survived Detroit's decline in the latter half of the century, but it has also maintained: "high occupancy rates, a racially diverse population and a strong commitment to maintaining Mies's architecture" (Lange, 2012).

However, much like Corb's Quartiers Modern Fruges, the majority of the residents of Lafayette Park didn't come to view the stark, minimalist modern interiors of Lafayette Park as an imposition of order and function, but rather saw the spaces as blank canvases onto which they could impose their own abstract humanity. As In their new book, "Thanks for the View, Mr. Mies," released in 2012, editors Danielle Aubert, Lana Cavar and Natasha Chandani, offer a view of Lafayette Park that is very different from the accustomed historical account of many of Mies' modernist classics.

"While they may have strong aesthetic preferences, the residents we spoke with do not necessarily favor midcentury modernism in their interiors or architecture. But they make it work:.. interiors in the Lafayette Park townhouses can function as blank canvasses for a variety of decorating styles. Indeed, the best design doesn't force a personality on its residents. Instead, it helps them bring out their own." (Aubert, Cavar, Chandani, 2012).

The book offers a fascinating account of the way in which people occupy personal space. While it is true that there has been a concerted effort to maintain the exterior expression of the townhouses and high rise towers, the interiors of the apartments and houses have become highly personalized homes. Certainly, some people are drawn to Lafayette Park because they are architecture enthusiasts who wish 
to preserve Mies' vision, however these people are in the vast minority. The majority of the residents of Lafayette Park have built a healthy, livable community by imposing their own humanity, wants and needs on to a development that was conceived of in an ideological, deterministic framework which sought to inspire specific behavior.

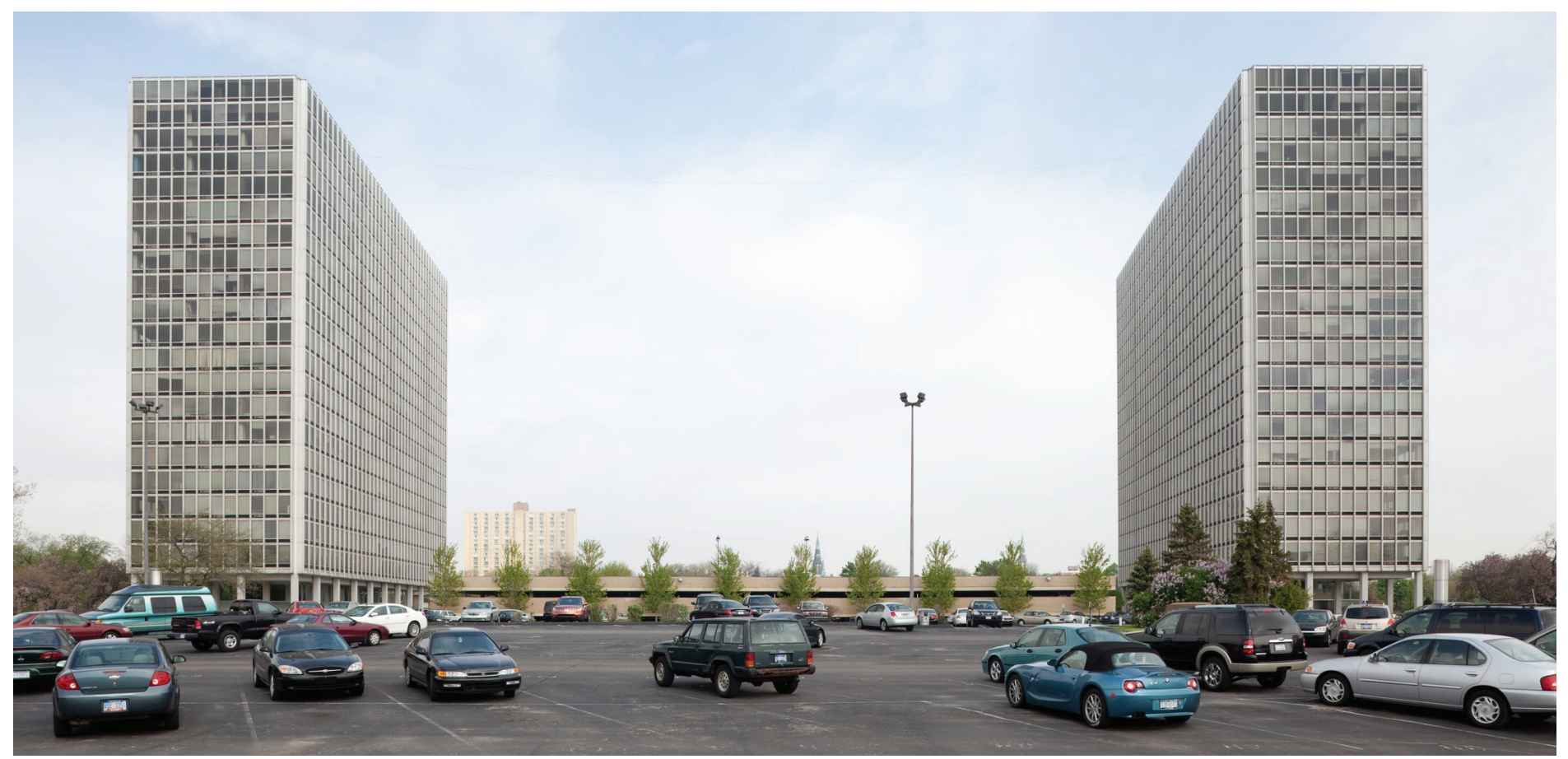

Figure 1.9 Lafayette Park High-rise Towers

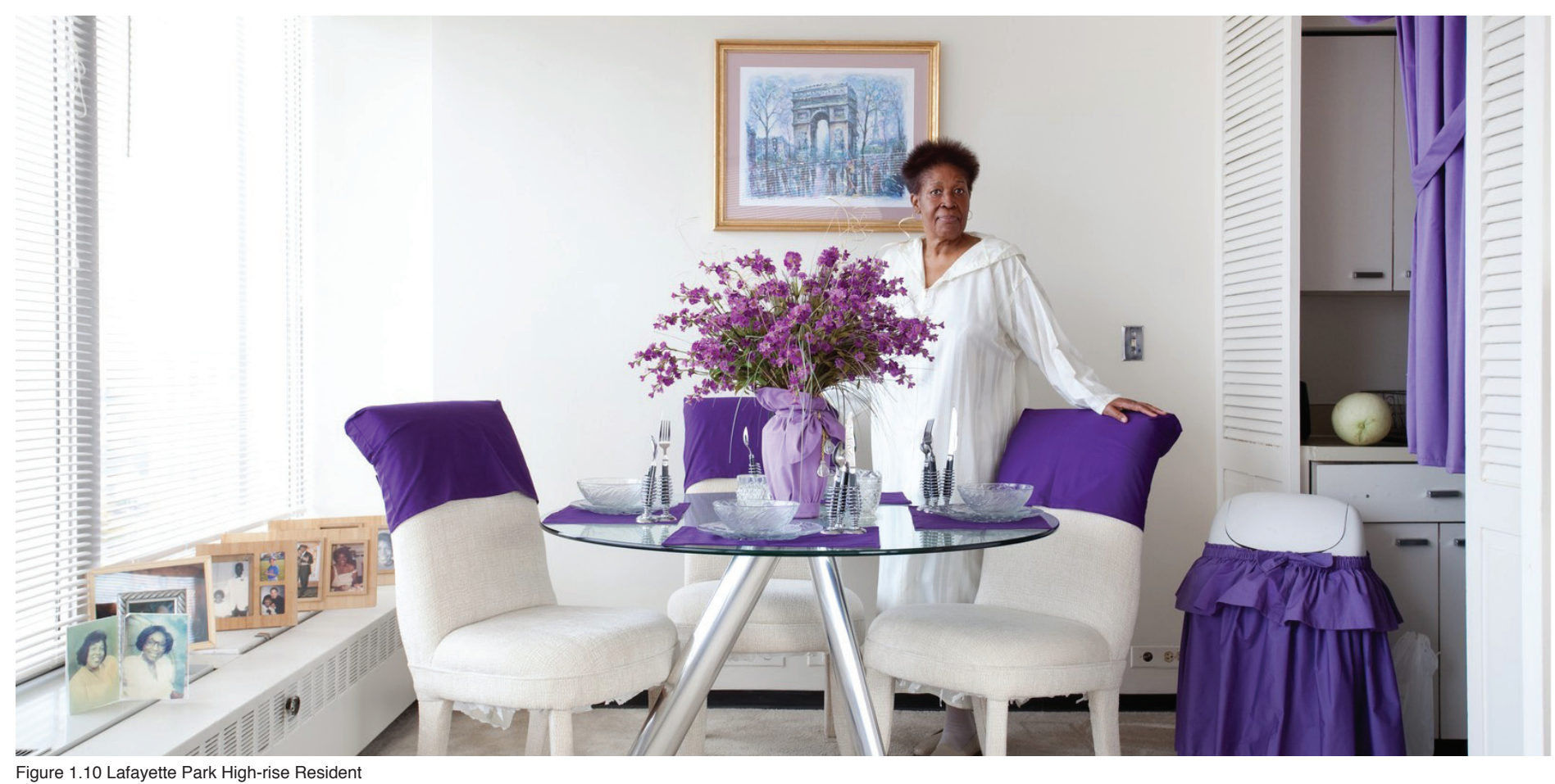




\section{Chapter 2 - The Decline of Industrial Manufacturing in Detroit}

\subsection{Waning Industry and the Decline of Industrial Detroit}

The success and expansion of the auto industry which began in the 1910's fueled a growth spurt in Detroit making it the 4th largest city in the country by 1950. At its peak in the mid 1950's, Detroit's population had surged to nearly two million people. Much of the population surge can be attributed to the northern migration of people from the south, many of whom were African American, who moved to Detroit to find work at one of the big three auto companies; General Motors, Chrysler, and Ford. By 1940, "Ford was one of the largest private employers of African Americans in the United States." (Sugrue, 2007).

In 1941, after lengthy struggles, the United Auto Workers (UAW) eventually succeeded in establishing an auto workers union. The contracts that the UAW negotiated resulted in generous wages and benefits for all auto workers, propelling them into the new 'blue collar middle class'. As Sugrue (2007) states: "By the mid-twentieth century, a majority of Detroit residents were homeowners; many auto workers saved money to send their children to college; and tens of thousands could even afford lake-side summer cottages".

It was not long after unionization that the Detroit based auto industry began to restructure. As a result of the effect on the bottom line profit that the UAW's victories spawned, the big three began to decentralize production. They first opened production plants in Midwestern "suburban green fields" (Sugre, 2007), and then increasingly (and perhaps ironically), in the American south. The reason for the southern migration of production was simple; the industry was seeking non-unionized, cheap labour to exploit in order to drive up company profitability. At the same time, the industry was increasingly introducing automation, which replaced many assembly line workers. As a result: "Between 1948 and 1967-when the auto industry was at its economic peak-Detroit lost more than 130,000 manufacturing jobs" (Sugre, 2007).

Further, the loss of Detroit's manufacturing jobs coincided with post war suburbanization (Fig. 2.2), resulting in large swaths of the city being abandoned by (mostly) middle class whites. This left the city further segregated along race and class lines. Furthermore, due to the practice of red-lining; whereby

minority neighborhoods were classified by the Home Owners Loan Corporation as being hazardous and undesirable, many urban neighborhoods experienced mass disinvestment resulting in further inner city blight. As a result, in 1967 Detroit: "erupted in one of the worst race riots the country had ever seen" (Sugre, 2007)(Fig. 2.1). After having experienced massive job loss, sububanization, race riots, segregation and white flight, by the end of the 1960's Detroit was left gutted and largely abandoned.

Things would only fair worse in the 1970's, as the oil crisis of 1973 and increasing foreign competition ravaged the American auto industry, resulting in even further job loss. 
As a result, Chrysler filed for bankruptcy in 1979, while Ford and GM faced serious deficits (Sugre, 2007). Detroit hasn't fully recovered, having since suffered though corrupt leadership, disinvestment in city services, and a lack of adequate transit infrastructure. Today, the city's population stands at roughly 800,000 but is steadily climbing as people are returning to the city, lured by cheap real estate and a rich cultural legacy.

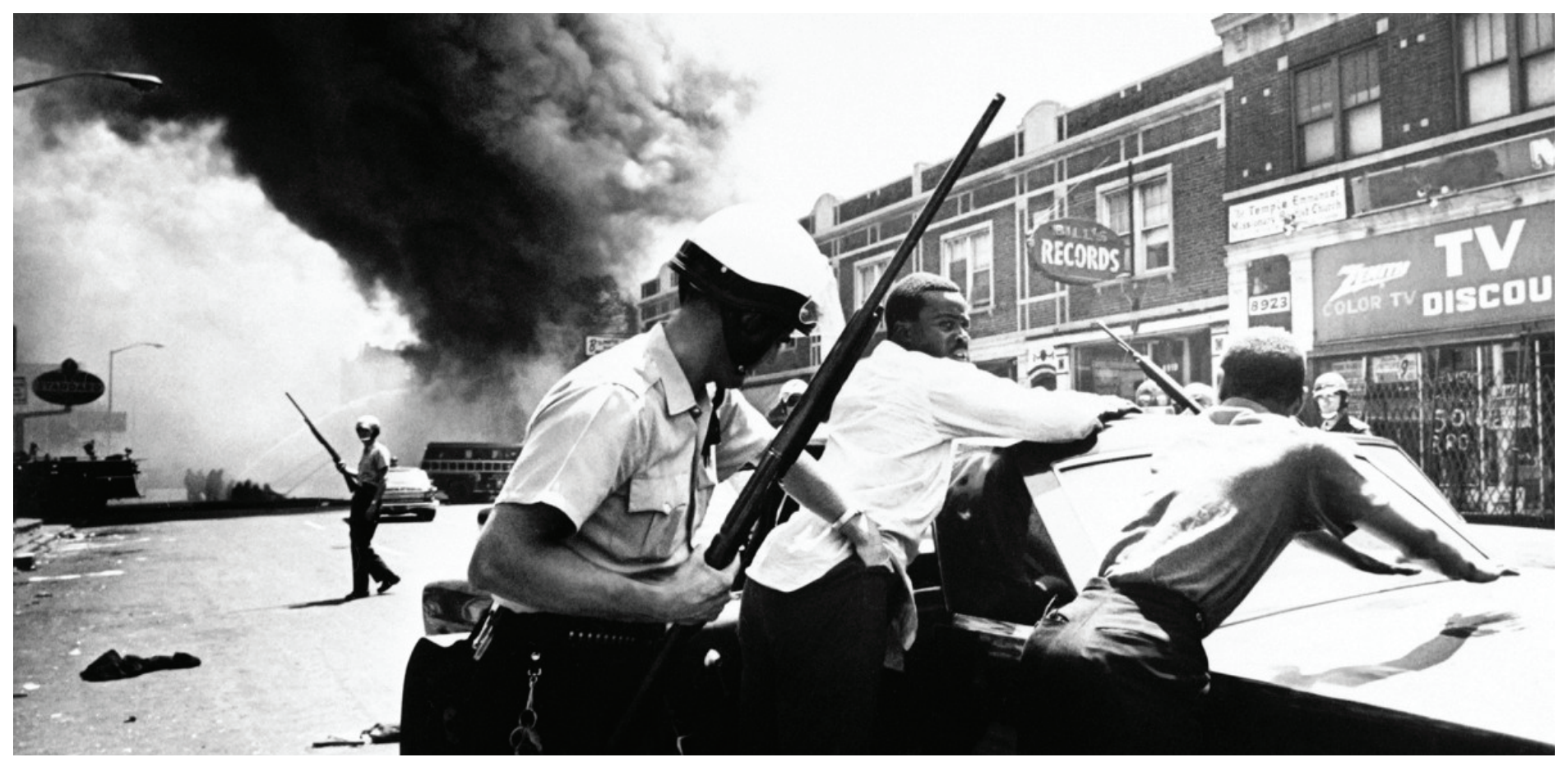

Figure 2.1 Detroit Race Riots 1967

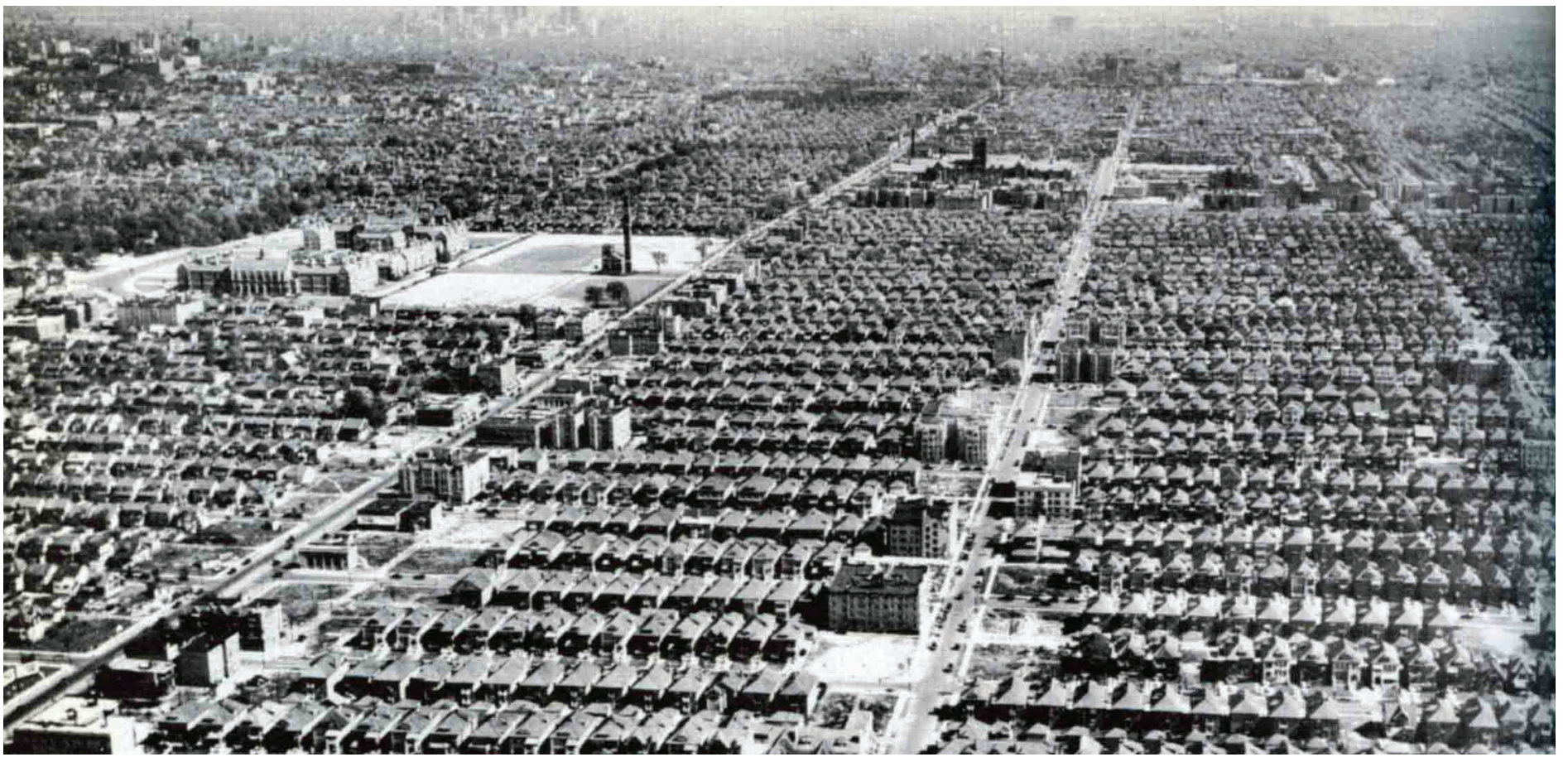

Figure 2.2 Detroit Suburbs 1960's 


\subsection{Cultural Activity in Detroit's Inner City}

Mirroring Detroit's decline was the rise of movements in arts and culture. This is perhaps most notably represented by the murals painted at the Detroit Institute of the Arts (DIA) by Diego Rivera in the 1930's (Fig. 2.3). When Rivera arrived in Detroit in 1932, the country was in the midst of the great depression. The depression hit Detroit hard, shedding thousands of jobs in the auto sector, leaving much of the city in poverty. Rivera was commissioned (perhaps ironically by Edsel Ford) to depict the Industry of Detroit in a series of murals painted on the walls of the DIA. While the murals were generally seen by the art world as a monumental artistic achievement, they did not come without controversy; a Detroit news editorial called the murals "coarse in conception ... foolishly vulgar ... a slander to Detroit workmen ... un-American." (Gonyea, 2009).

Detroit of the 1920's and 1930's was also significant for the pioneering of African American big band jazz music, with bands such as the Mckinly Cotton Pickers making significant contributions to the genre. In the 1940's Detroit became a important city for the development of blues and gospel music, as groups such as the Detroiters gained national attention.

In 1950's Detroit musicians made significant contributions to Gospel, RnB, and early rocknroll. The Meditation singers out of Detroit were one of the most popular female Gospel groups of the era. Perhaps the greatest Gosepl singer of all time, Aretha Franklin, arose to fame out of Detroit in the late 1950's. The gospel and RnB groups of the 1950's set the stage for one of Detroit's most significant contributions to popular music, Motown Records, founded by Berry Gordy in Detroit in the early 1960's. Motown was home to many popular recording acts including Marvin Gaye, Stevie Wonder, Diana Ross \& the Supremes, the Jackson 5, and many more.

In 1955 Detroit based artist Marshall Fredricks was commissioned to build "the Spirit of Detroit" (Fig. 2.5) . The sculpture, commissioned by the city was meant to represent "hope, progress, and the "spirit of man."(Encyclopedia of Detroit). The sculpture was erected in 1958 and remains to this day a symbol of the strength and resilience of the city.

In the late 1960s, Metro Detroit was the epicenter for the creation of heavy rock music, with the MC5 and lggy and the Stooges pioneering a new sound which would become the precursor to punk rock. Other significant rock bands from the Detroit area of the 70's include Bob Seger, Alice Cooper, The Romantics and Grand Funk Railroad. 
The Detroit area of the 1980's is generally accepted as the birthplace of the Techno music movement, which today has grown into one of the most popular music genres worldwide. The three musicians most frequently credited with giving birth to Techno are Detroit area residents Derrick May, Juan Atkins, and Kevin Saunderson.

Detroit has also made significant contributions to hip-hop and rap music. Notable Detroit hip-hop artists include: Aaliyah, Eminem, Royce Da 5'9" Teairra Mari, Obie Trice, Rock Bottom, and Danny Brown.

Detroit is also home to significant public art initiatives such as the Heidelberg Project (Fig. 2.6) and the Eastern Market murals, among many others. The Library Street Collective is a Detroit based non-profit organization that fosters grass roots artistic movements and has continues to contribute to the rich cultural history of the city.

This is, of course, only a very basic and far from comprehensive overview of the contribution that Detroit based artists and musicians have made to the world.

These movements, however, came about despite the challenges of the city, despite the capitalist determinism of industry, despite the dehumanization of the assembly line, despite the ordered functionalism of modernism, despite (and in some cases, because of) the blight and decay that happened as a result.

"Weeds always come back. The whiter the wall, the quicker it succumbs to dirt." (Till, 2009, 34).

The "revitalization" or "regeneration" of Detroit should be a delicate process. As Brian Doucet (2017) identifies, "Rather than being a rising tide that lifts all boats, the regeneration that is taking place here means this area (downtown) is pulling away - economically, socially and racially - from the rest of the city. It is becoming whiter and wealthier than the rest of Detroit, and the private services and amenities that Dan Gilbert and others have initiated mean that access to these resources is becoming highly fragmented along racial and class lines". 


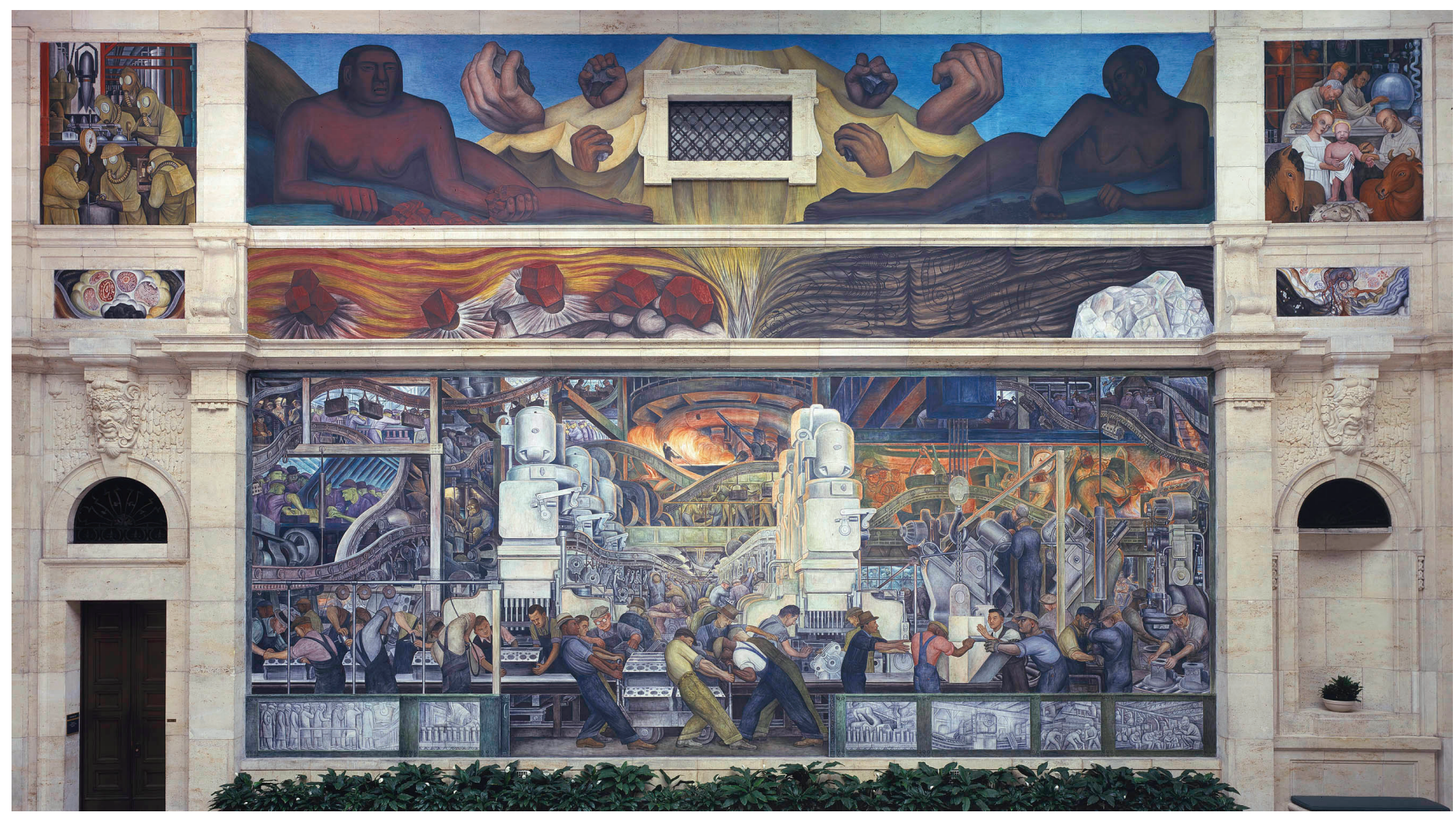

Figure 2.3 Diego Rivera Detroit Mural

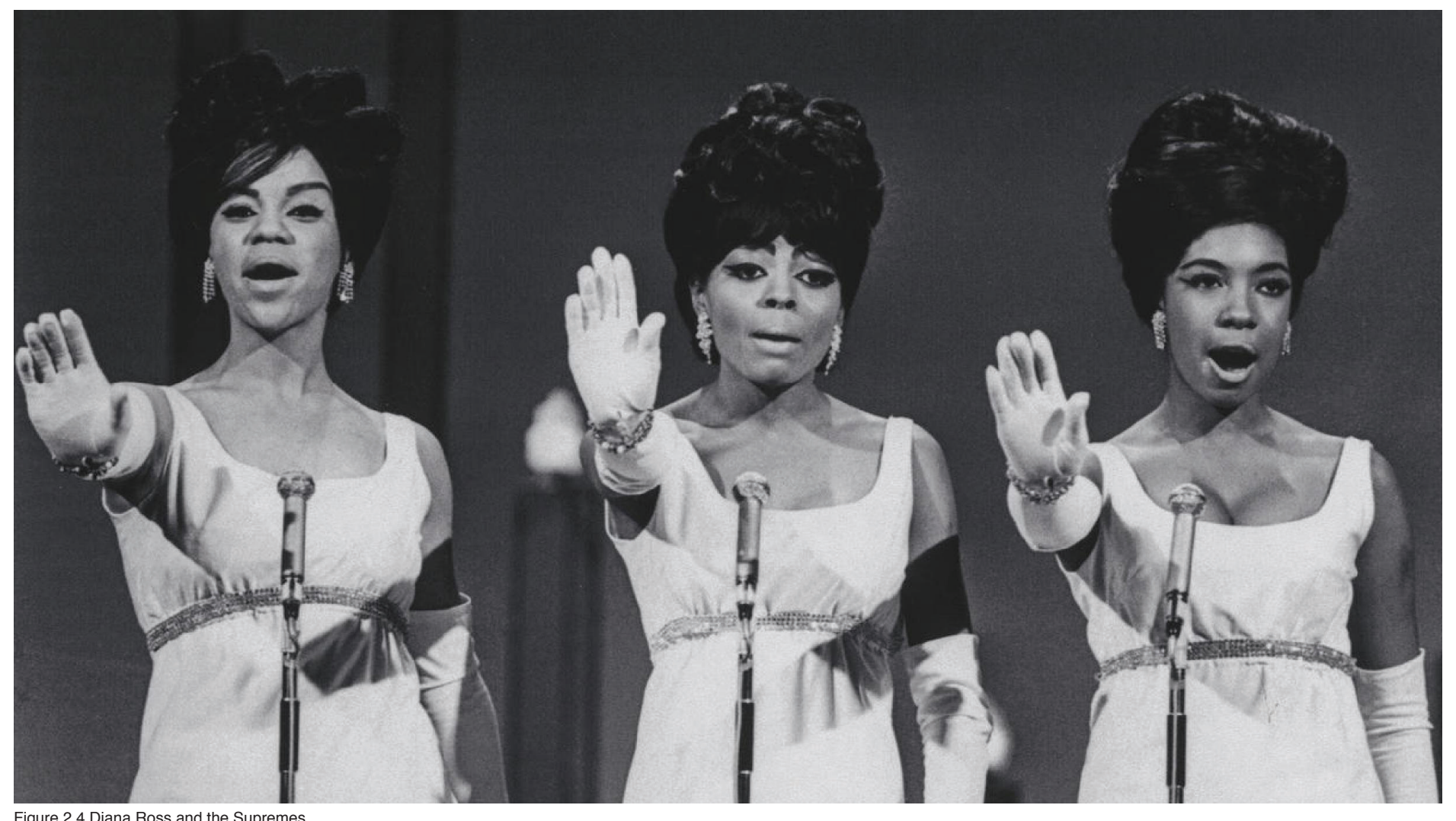



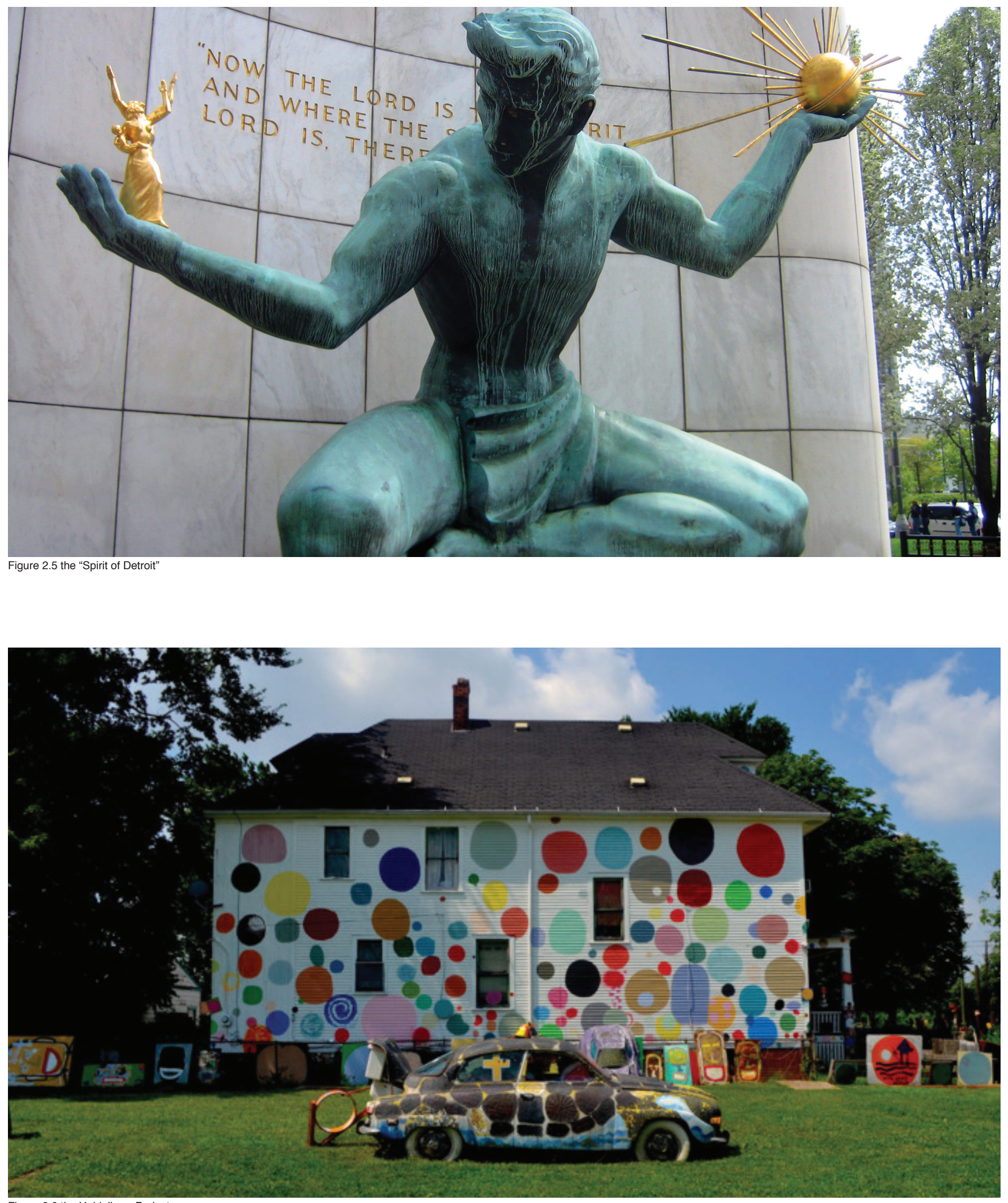


\subsection{Detroit's Abandoned Industrial Infrastructure}

Detroit Future City, is a Detroit based nonprofit organization which is in charge of the implementation of tge 'DFC Strategic Framework', a “50-year vision for the City of Detroit” (DFC, 2018). The DFC issued a report in May 2018 titled 'Vacant Industrial Properties - An Opportunity for Innovative Adaptive Reuse'. In the report, the DFC identifies that "there are almost 900 vacant industrial buildings spread across the city.. Many of these buildings abut residential neighborhoods in some of the city's most disadvantaged areas. Without a strategic approach to re purposing these properties, they will remain fallow for years to come, posing threats to public health and safety, and undermining Detroit's recovery." (DFC, 2018).

Further, "the Detroit Future City Strategic Framework advocates for innovative, adaptive reuse of some of the city's vacant industrial sites. The goal: to put these properties back into productive use; economic, creative, and ecological reinvention for the benefit of Detroit residents and communities, and the preservation of some of the city's history." (DFC, 2018).

As a rapidly changing and gentrifying city, and as a city with a deep cultural legacy, the abandoned industrial buildings of Detroit, in their scale and ubiquity, present a unique opportunity to explore an innovative adaptive reuse strategy. Through consultation with the Detroit Future City organization, an conveniently situated Albert Kahn designed abandoned industrial building - the Fisher Body \#21 building, was chosen as a site for a design exploration for the purpose of this thesis. The building, it's context and its history will explored in depth later in this document.

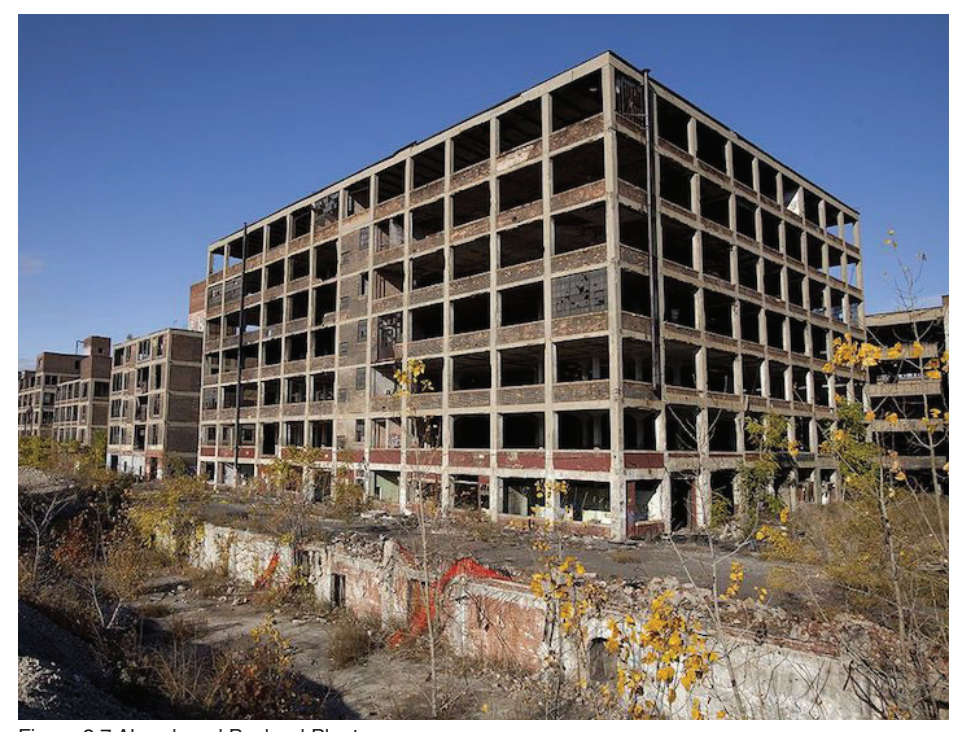

Figure 2.7 Abandoned Packard Plant

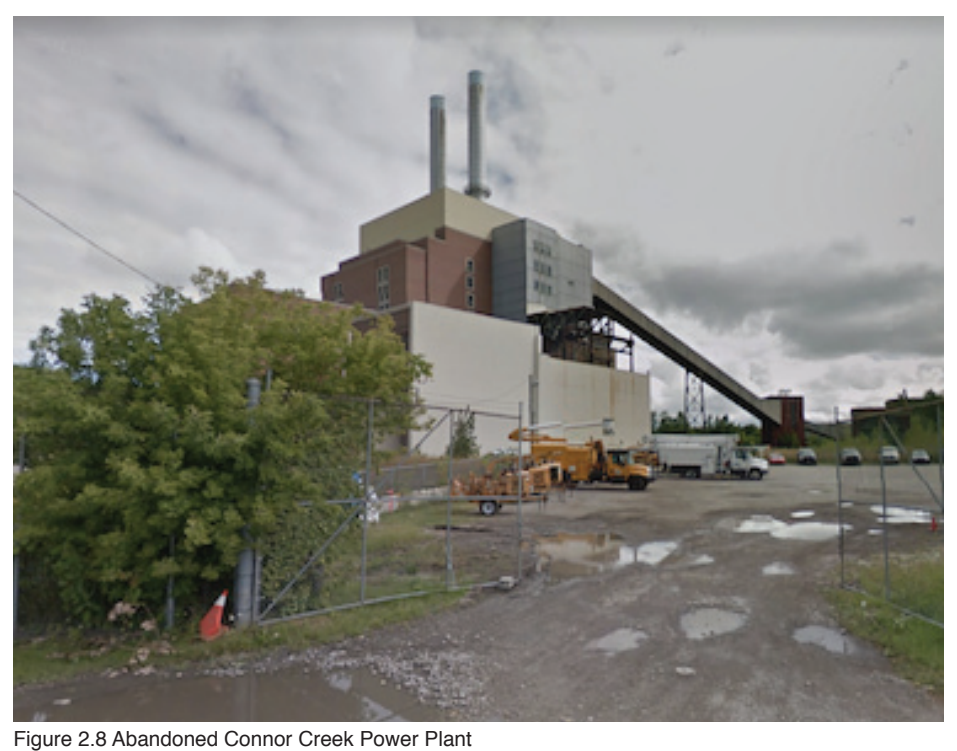

Figure 2.8 Abandoned Connor Creek Power Plant 


\section{Chapter 3 - Precedent Case Studies}

The precedent case study projects presented in this chapter represent a cross section of spaces that have been re-used, re-purposed, or re-appropriated for a variety of uses.

Artscape Wychwood Barns is a adaptive reuse project which re imagines a former industrial streetcar repair facility as a cultural community hub. Wychwood Barns includes artist live/work studios, a community garden, an event space and a public gallery.

The Detroit Adventure Center is an example of a community initiated, not for profit adaptive re-use project that makes use of previously abandoned industrial manufacturing facility for the purpose of a nature learning center which explores the natural resources of Michigan's Park system.

The Russell Industrial Center is an adaptive re-use project in which artists and other makers in Detroit occupied and repurposed a 2,200,000 sqft Albert Kahn design former auto body industrial complex.

Streetmekka Esbjerg is an NGO funded adaptive re-use project which transformed a formerly abandoned roadhouse to be used as a youth oriented community center.

In each case the pre-supposition that the experience, perception and use of a building is determined by the architects original intent is subverted. The buildings and spaces take on new narratives and meanings including leaning, creating, playing, and moving. These precedent studies served to inform a new adaptive reuse proposal contain herein. 
Joe Lobko Architect Inc. - Artscape Wychwood Barns, Toronto, Canada

Atscape Wychwood Barns is a collection of former industrial streetcar housing and repair sheds, which have been re-purposed as artists' housing and community cultural facilities. It is a convergence of covered public space (fig. 3.1), small rental live / work apartments, offices for non-profit organizations, a greenhouse, and a public park. The building features a long, rectilinear floor plan, which is ideally suited to community events, gallery showcases and farmers markets. Adaptive reuse strategies included restoring the brick facade, replacing the glazing, and providing new outdoor park amenities. As such the building sits within, and is a welcome compliment to, the surrounding well-established residential neighborhood of Wychwood Park / St. Clair West.

Built in three stages between 1913 and 1921, the barns encompass 53,000sqft of floor space, and occupy 1 acre of a 5 acre site. The barns functioned as a streetcar housing and repair facility until the Toronto Transit Commission took over the space in 1954, at a time when "the TTC was considering phasing out streetcars" (Artscape Wychwood Barns, 2018). As a result, the barns were re-purposed as a storage facility, and existed as such until 1978 when the barns were decommissioned. Over the subsequent years the barns fell into disrepair, and in 1996 they were scheduled to be demolished.

However, as a result of grass roots community organization led by City Councillor Joe Mihevc, a campaign to save the barns got underway. This resulted in the TTC eventually selling the site back to the city of Toronto as opposed to a private developer who would've demolished the barns to make way for new development. The city of Toronto then commissioned Artscape, a group of not-for-profit organizations with a mission to make space for creativity and transform communities to develop a vision for the site. Over the subsequent years, Artscape, along with the city, architects, city planners, private stakeholders, and the local community, developed a vision and master plan for the site which came to include a series of community spaces, a commercial greenhouse and sheltered garden, 26 live/work housing units, 15 work studios for local artists, a children's theatre and office spaces for local not-for-profits, all surrounded by a new municipal park.

In addition, the Wychwood barns became one of the first LEED Gold Heritage buildings in Canada. Susutanability features include a large cistern to collect roof water for irrigation and use in washrooms, extensive day-lighting and natural ventilation, as well as a ground source heat pump HVAC system.

The Artscape Wychwood Barns opened to the public in 2008, and has since become "the social heart of the neighbourhood" (Artscape Wychwood Barns, 2018). This project provides a successful case study which demonstrates that a large former industrial site can be re purposed to serve the needs of the surrounding community while operating under an alternative economic model of development. 


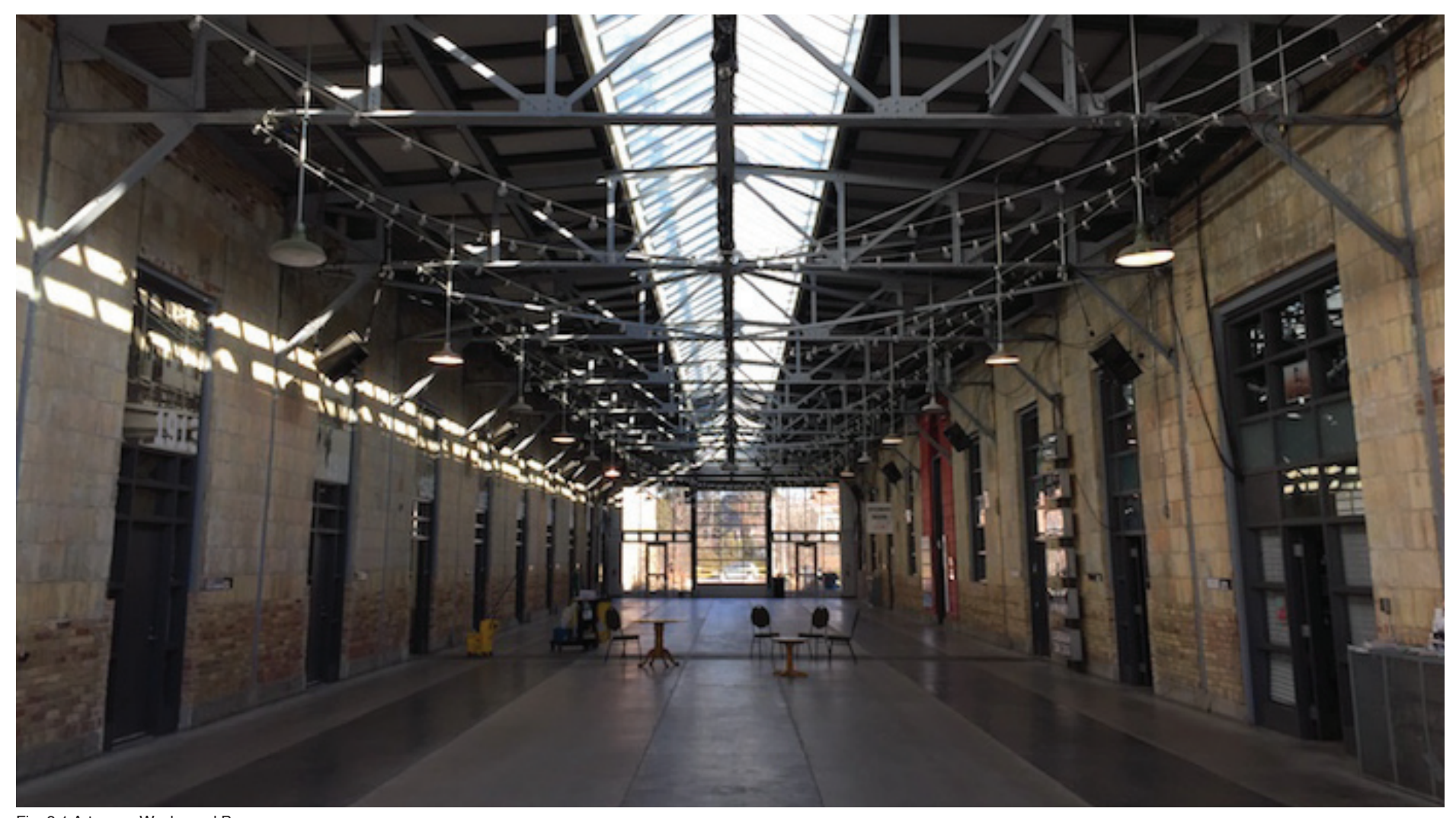

Fig. 3.1 Artscape Wychwood Barns

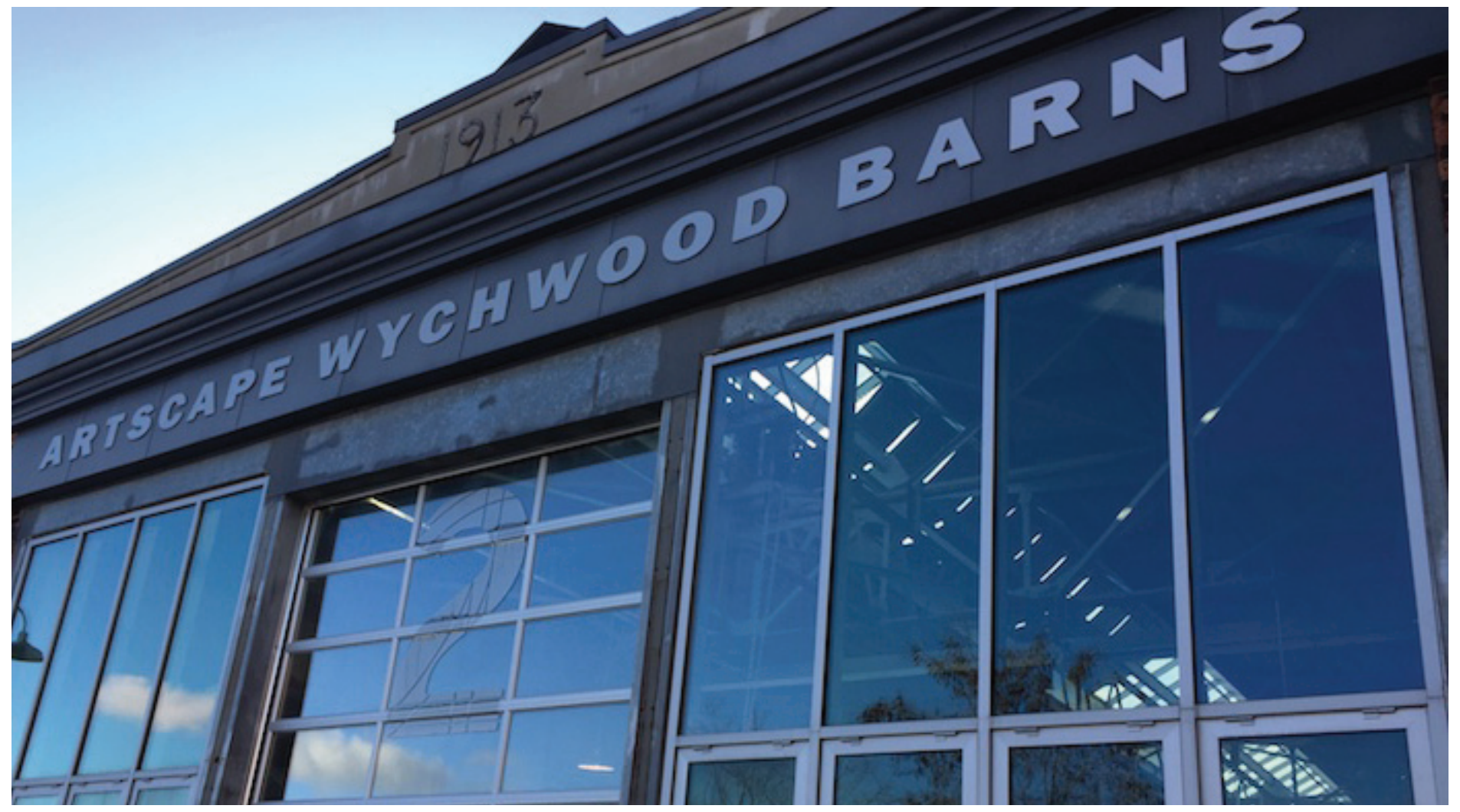

Fig. 3.2 Artscape Wychwood Barns 
Hobbs + Black Architects - Outdoor Adventure Center, Detroit USA

The Detroit Adventure Center is an example of a community initiated, not for profit adaptive re-use project that makes use of previously abandoned industrial manufacturing facility for the purpose of a Nature learning center.

The Globe Building, originally built in 1892 (fig. 3.3) was one of a complex of 6 buildings on the Detroit river waterfront that originally housed the Dry Dock Engine Works Company. The Engine Works was significant in its role in the maritime history of the Great Lakes as a notable manufacturer of steam engines used for freight and passenger boats. The Globe building is a large steel truss and brick structure, and features large open spans meant which at one time housed a large machine shop within. Described as "remarkable" (Apel, 24), the Globe building "is an early example of an industrial structure entirely supported by a steel frame with brick curtain walls." (Library of Congress, 1961).

Waning industry in Detroit meant that the The Globe Building was decommissioned in the 1960's. In 2006, efforts were made to convert the riverfront property into Condo and Retail space, but due to the economic downturn of 2007 / 2008, the project never materialized. In 2009 the Michigan Department of Natural Resources put forward a plan to build a \$34 million nature learning facility in the Globe building. Through a partnership with private developer the Roxbury Group, the plan was finalized in 2013. In 2015 the renovation was complete, and the Outdoor Adventure center opened to the public in July of that year.

The rehabilitation effort preserves and highlights the majority of the original structural steel and interior and exterior brick walls. Further, the architects re-furbished and reused over 40,000 of the buildings original bricks. Various simulated activities provide simulations of outdoor recreation experiences, while exhibits and displays feature the natural and cultural resources and outdoor activities that are typically found in Michigan's parks and recreation areas.

In its first year, the Outdoor Adventure was visited by over 100,000 people. The Outdoor Adventure Center is widely regarded as a successful adaptive reuse project, both in it's preservation of an important part of Detroit's industrial heritage, and as a valuable cultural resource for the citizens of Detroit and tourists alike. 


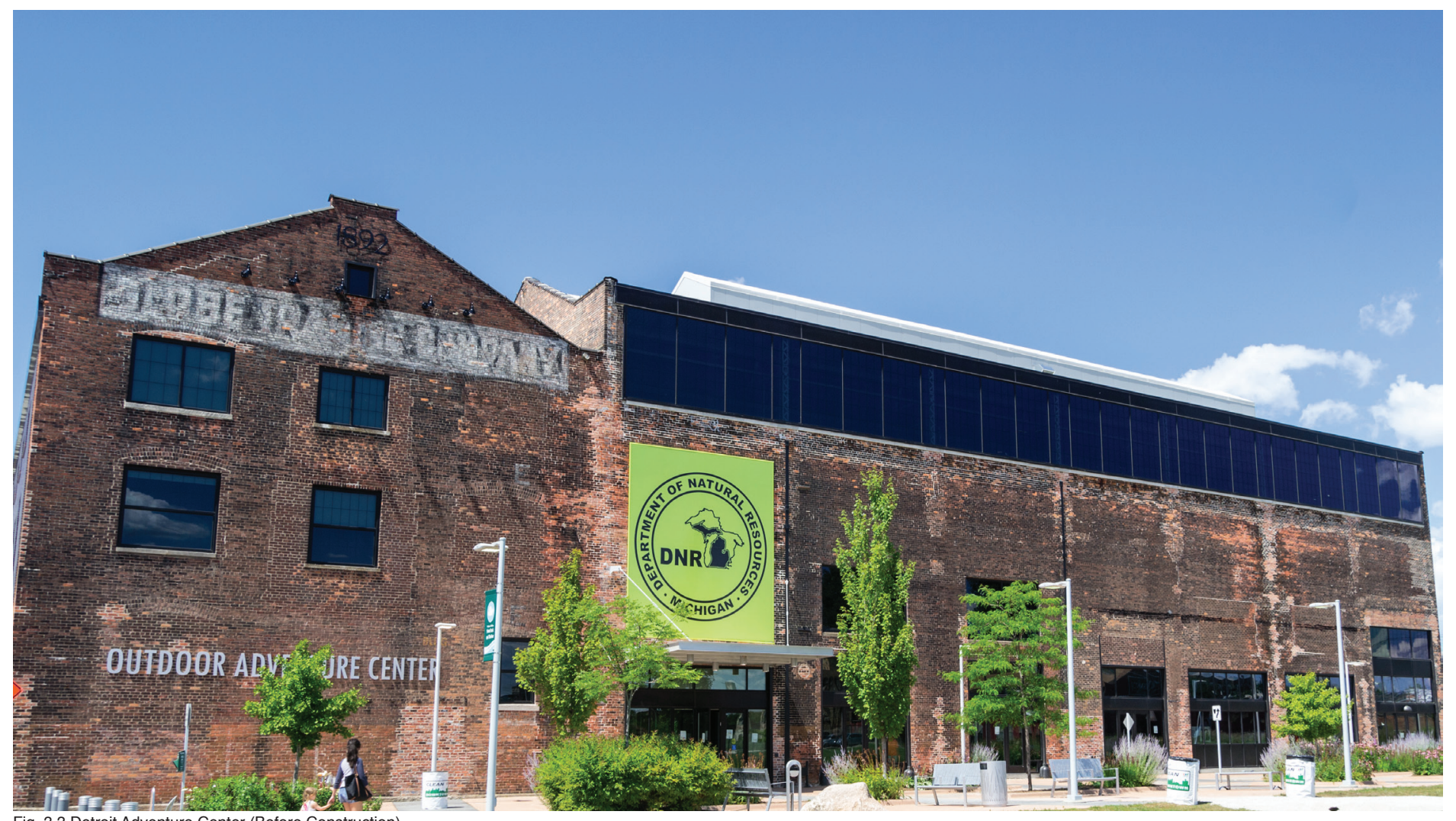

Fig. 3.3 Detroit Adventure Center (Before Construction)

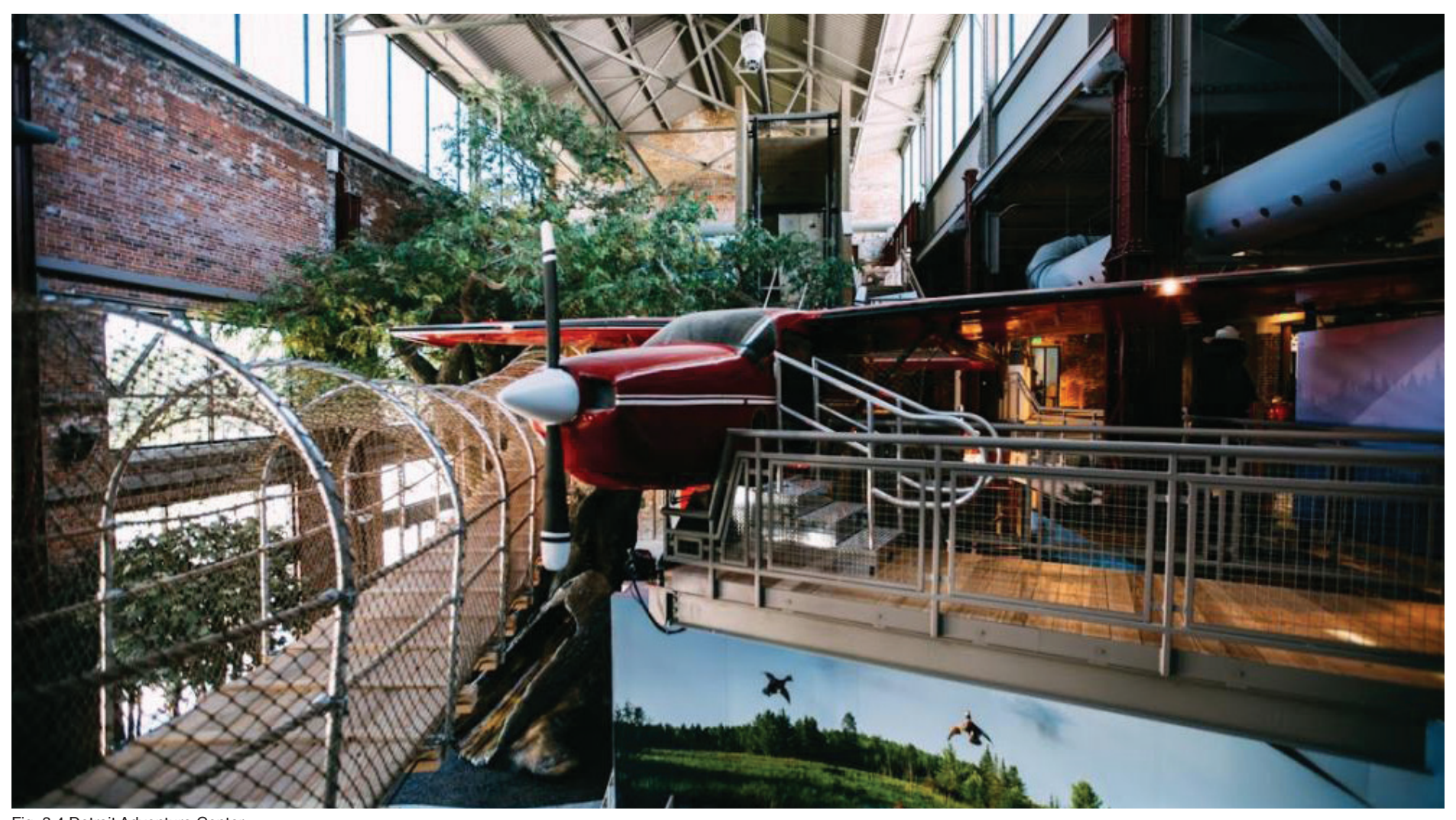

Fig. 3.4 Detroit Adventure Center 
Albert Kahn and Associates - Russell Industrial Center, Detroit USA

The Russell Industrial Center (fig. 3.5) is an adaptive reuse project that transforms an early 20th century Industrial Complex in Detroit's Milwaukee Junction into a mixed use maker space which includes artist studios, workshops, architectural offices, designers, food stores, shops, printers, and other makers.

The industrial building, originally built in 1915 and designed by Albert Khan, is a 2,2000,000 square foot complex which originally housed the Murray Auto body Company. Like much of Detroit's auto industry, restructuring in the 1950's and 1960's saw many of Detroit's automotive manufacturing companies move away from the city in search of cheaper labour elsewhere. The Murray Auto Body Company was no different, and the Russell Industrial Center was decommissioned as a manufacturing facility in the early 1960's (Robiglio, 2017, p.103). The center was subsequently leased as an "industrial condo" by the Murray company until the 1990s, when a tornado severely damaged the building rendering it vacant for many years.

In 2003, The building was purchased by a property management firm for only $\$ 1,000,000$ (45 cents per square foot) and shortly after began repairing the building for reuse as artist spaces for cheap rental rates. In 2015. "studios, workshops, architecture offices, designers, musicians, food stores, shops, printers, and other makers occupied nearly 1,000,000 sqft, while events ranging from open air markets, to porn festivals, and film shooting animated the place, making it a destination again in Detroit's blighted map" (Robiglio, 2017, p.103).

In the case of the Russell Industrial Center, the project did not involve a top down over-arching strategy developed by a single architecture firm, but rather relied on the participation of and collaboration of large number of local and international stakeholders; artists, designers, architects, makers, and other creative people and organizations, who sought to create spaces that were conducive to creative and productive work.

As Robiglio (2017) states in Re-USA, "much of Detroits comeback narratives are based on outsiders joining locals to share Motowns new destiny as a creative and production hub thank to an extensive, affordable, yet powerful industrial legacy" (p.103). 


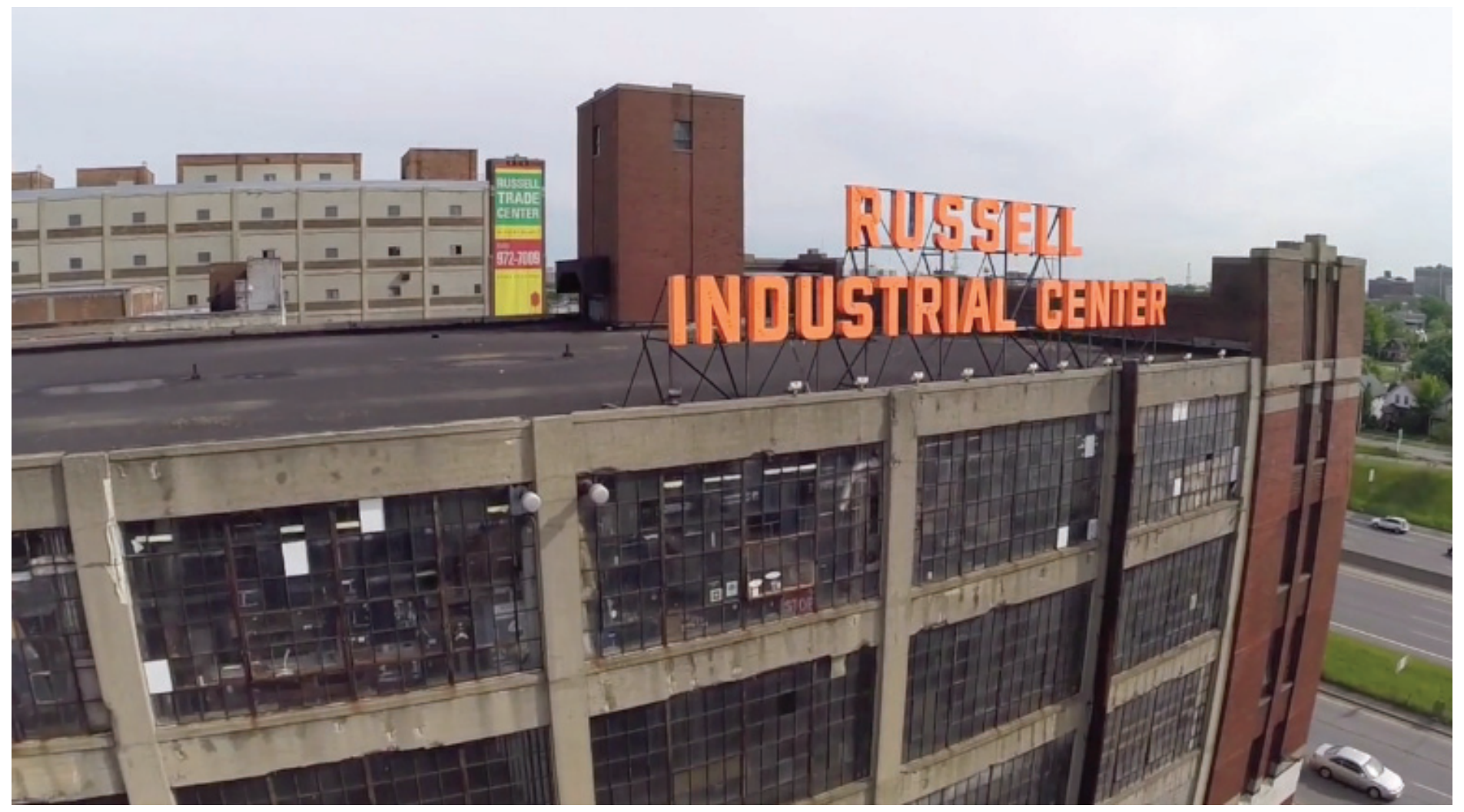

Fig. 3.5 Russell Industrial Center

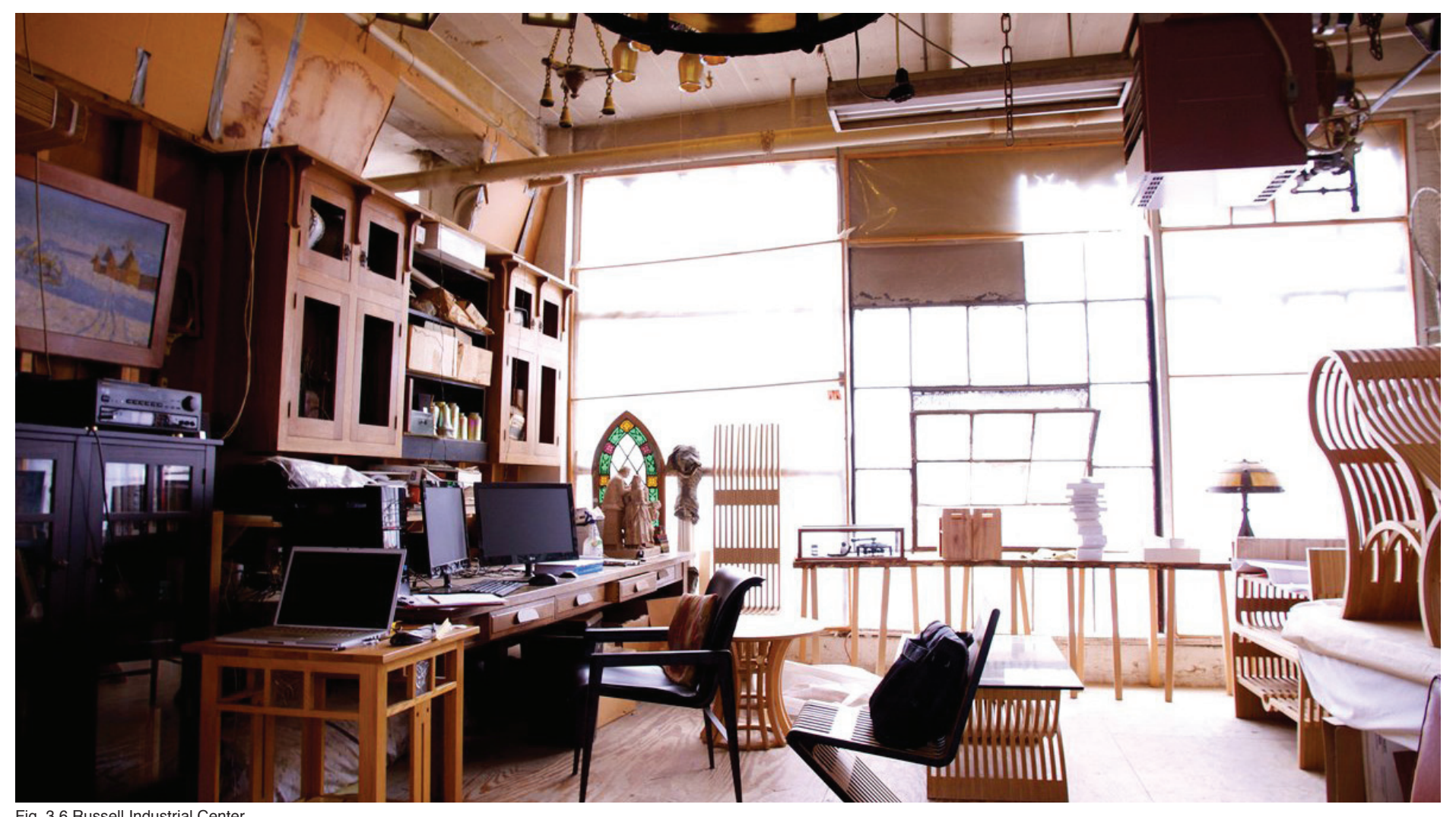

Fig. 3.6 Russell Industrial Center 


\section{Effekt Studio - Streetmekka Esbjerg, Denmark}

StreetMekka Esbjerg is an adaptive reuse project of an abandoned historic train engine roundhouse re- purposed as a facility for street sports and youth culture. Located in Esbjerg, Denmark, which is the fifth largest city and youngest big city in Denmark, the project is significant in its embrace and promotion of unorganized sports and youth culture in Esbjerg. Much of the programming of StreeMekka the first of its kind in the city, and features a skateboard park, parkour course, and workshop spaces for DJ education and street art. As such, the facility provides a place for kids, teenagers and young adults who do not feel at home in the mainstream sports culture. It also provides spaces and tools for young people to engage in artistic and musical pursuits that they may not have otherwise had access to.

The goal of the project was to keep the young people of Esbjerg out of trouble by keeping them engaged in street sports, culture, arts, and music, helping to keep them on a positive track while developing skills in creative fields.

The structure, a large, approximately 100,000 sqft 'roundhouse' style building was built in the early 20th century and used for years as a train engine depot until it was decommissioned to make way for Esbjerg's new train storage facility in the mid 1980's. To preserve the structure's 20th century industrial heritage, EFFEKT restored the structure's historic circular layout, then renovated and added five multipurpose halls, each with a distinct title: Concrete, Asphalt, Brick, Lounge, and Dance Mekka.

As stated by the Architects: "heavy industry is vacating the city centers leaving behind empty unused wastelands and buildings, often already occupied by skaters, street artists and the like." (EFFEKT, 2014).

Streemekka Esbjerg was developed and built by GAME, a Danish not for profit NGO, and Realdania, a philanthropic organization who endeavors to provide dynamic and creative spaces to accomodate Danish youth.

As Identified by Architizer: "In only a few months, Streetmecca Esbjerg grew into the largest organization in the municipality with over 4000 active members aging between 4 and 60 years of age" (2014). 

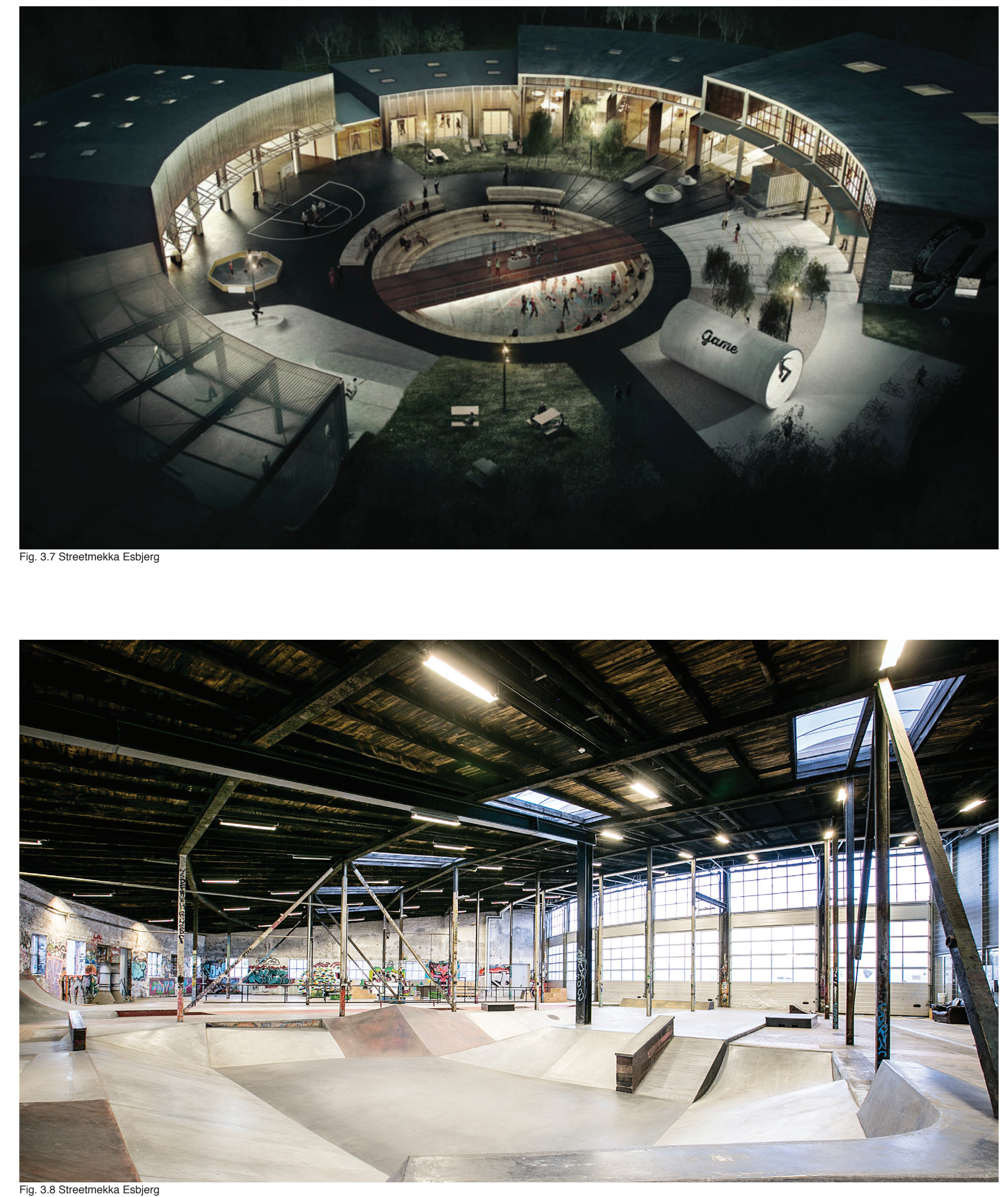


\section{Chapter 4 - Creative Space Architecture}

\subsection{Slack Space, Indeterminacy, User Determinism}

Slack space is a concept that runs counter to many of the professional ways that architects conceive of and create spaces. That is, architects routinely design spaces that are flexible only in a number of predetermined and prescribed ways, essentially dictating control and use over spaces in a deterministic fashion. Slack Space is described by architectural theorist Jeremy Till as "the provision of space which is not built over and not built in...it is just there....it can be appropriated...[it is] a space which you in-fill later." (Till, 2009, p.133)

In the UK, Guardian journalist Robert Booth used the term 'slack space' in an article to describe the phenomenon of empty shops being used by artists as studios, workshops and exhibitions spaces (Booth, 2009). In the article, Booth recognizes that "Slack space, is caused by business closures during recessions, and has provided a foothold for numerous successful businesses". Booth is referring to a number of high street closures in the UK amid the recession of the late 2000's which provided space for creative industries and performance venues that had previously been priced out of these areas.

Slack space can essentially be thought of as an idealistic and theoretical approach to design that does not dismiss the alternative, unconventional, or outlier uses of space, and instead focuses on an allencompassing flexibility and, perhaps, a sense of ambiguity. This is meant to welcome a broad range of users and a more eclectic, creative, user-determined range of uses. This approach to design theory suggests that there is, in a sense, a loss of agency of the architect over spatial production. Essentially, it is a variance from top-down deterministic design (assembly lines, domestic homogeneity), and instead treats the production of space as being beyond the designers control. To design or create a slack space is therefore conceive a space in which a myriad of opportunities with regards to activity and production can take place. This is a space whose meaning is not given but is forever becoming. As Lebfevre said in the Production of Space: "The users space is lived - not represented or conceived."

The concept of slack space as a design strategy will be employed in the adaptive reuse proposal contained herein.

"Any specialized kind of knowledge production, whether disciplinary or interdisciplinary, is inadequate to grasp the contemporary city, and this grasp would have to lead towards a new trans-disciplinary knowledge production with a necessarily hybrid, experimental and indeterminate form." (Hercsher, 2012) 
The question then raised in the production of slack space is; how can we as architects, conceptualize the production of space as indeterminate, ambiguous, and in a state of becoming? Traditionally, the architect's modes of representation; be it the sketch, render, or the 3D walk-though, suggest an ideal, sterilised, static, "perfect" world. Jeremy Till claims that: "instead of using these traditional methods we must adopt more experiential and evocative forms of representation and communication.. with an experiential and dynamic character to them that require the designer to consider how a space would be used by future users and the potential experiences had" (Till, 2009, p.140). As a tactic for interpreting the dynamism of space, this approach is more inclusive than the top-down prescription of the way in which users ought to use space.

This same concept was explored in depth by the 'activist' architects of the late 1960's and early 1970's, notably Archigram, Super Studio and Bernard Tschumi who was a "left wing critic of modernism, drawing his aesthetic and political inspiration from the Situationist international" (Gartman, 2009, p.380). In his design for the follies at Parc de la Villette in Paris (fig. 4.1), Tschumi's goal was to create an "event architecture", spaces of free activity in which a "non - hierarchical, nontraditional society could be anticipated. He argued that such spaces could be created only by breaking open the closed grids of modernism and providing for voids in which unexpected events could occur" (Gartman, 2009, p.380).

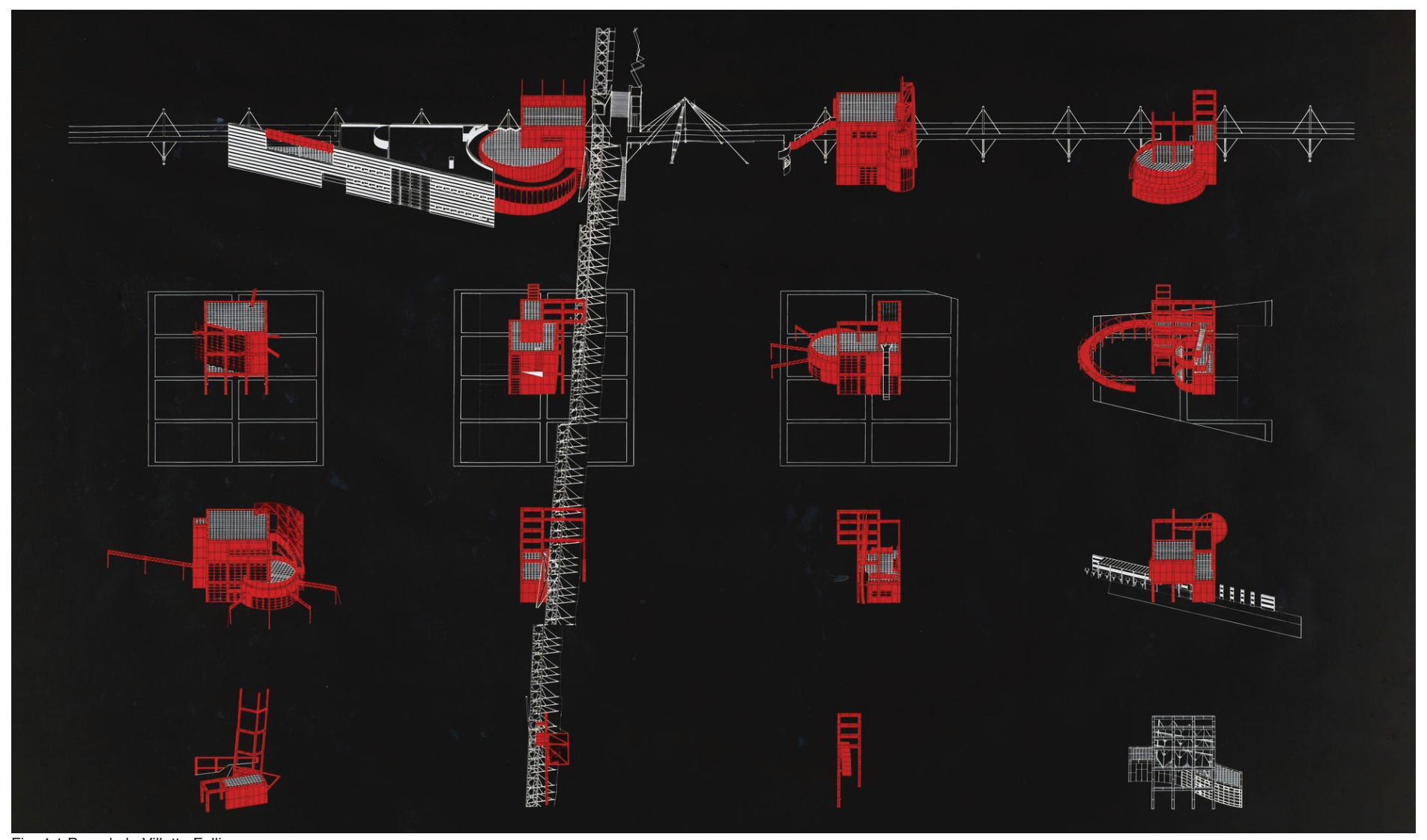


To conceive of space as dynamic, as places whose meaning is not given but in a forever state of becoming, in which the users space "is not represented or conceived, but lived", can be applied as a conceptual design theory in the production of space. This is not to say, however, that such an approach means that there is a denial of basic building services that architecture need provide (such as washrooms, circulation cores, fire rated partitions, space conditioning, acoustic separation, accessibility, et al.). It is to say, then, that the architects role in the production of such space is to ensure that essential services are provided to the highest of standards, and that 'slack space' can only occur adjacent to this necessity. Further, to provide spaces of leisure and play, such as sports facilities, art studios, and classrooms, does not run counter to this idea. Such spaces provide users with a facility to be in a dynamic state of becoming; to facilitate the production of movement, the production of craft, and the production of knowledge. 


\subsection{Temporal Disruption: The Aesthetics of Ruins}

"Ruins contain not deliberately organized assemblies devised to strike chords and meanings through associations, but fortuitous combinations which interrupt normative meanings... Such encoded arrangements or organized assemblies organize things within spaces, creating patterns which claim normativity as part of the mundane and systemic production of the spectacular and ornamental. The happenstance montages of ruined space, however, comment both ironically on the previous fixed meanings of their constituent objects, and the ever so carefully arranged montages of commodified space. Pleasurable by virtue of the interaction between objects containing different semiotic charges, and the arbitrary relationships between different forms, shapes, textures, and materialities, the unending diversity of unencoded material juxtapositions stimulate ineffable sensations" (Edensor, 2005, p.77).

Contemporary explorations into the desirable aesthetics of ruins, as well as the embrace of disorder, decay, and the embrace of 'Conterpreservation' techniques with regards to the adaptive reuse of buildings have informed part of the adaptive reuse strategy contained in this thesis. The preservation of the fortuitous disorganization that becomes part of the history, memory, and palimpsest of the object (in this case the industrial building) can work to stimulate sensations such as creativity, collective memory, pleasure, and temporal disruption which can foster imaginative cultural production.

In her book, 'Counterpreservation, Architectural Decay in Berlin since 1989', author Daniela Sadler (2011) explores how counter cultural groups have employed a 'Counterpreservation' strategy to the repurposing of Soviet-era residential buildings in the former East Berlin. Initially, the goals for the occupation of these buildings was political: to create affordable housing, to promote diversity, and to foster creative exploration. Sadler argues that the case studies presented in her book such as the Tacheles (fig. 4.2) and the Haus Schwarzenberg (both examples of abandoned space appropriation), react against the gentrification and urban renewal which have defined Berlin's urban and architectural resurgence since the fall of the Berlin wall in 1989. The Berliner's embrace of ruination, Sadler argues, is an attempt to represent Germany's conflicted history, and collective memory.

In the book 'Industrial Ruins: Space Aesthetics and Materiality', Tim Edensor (2005) argues that across Western cities, there is an preoccupation with producing perfectly manicured landscapes and buildings. In contrast to these regulated spaces are the neglected sites of industrial ruins; places throughout America's rust belt and other neglected industrial landscapes, in which transgressive and dynamic activities occur. Further, Edensor argues that there is a danger in destroying such urban landscapes and buildings through policies that privilege homogeneous new developments, which only serve to embolden gentrifying forces, especially in cities that are on the cusp of mass re-investment and development. Industrial ruins can blur boundaries between past and present and are intimately tied to memory and a sense of place. 
Part of the design strategy contained herein will embrace the preservation of the fortuitous disorganization, appropriated canvas and inherent ruinous aesthetic of the chosen site. Such an approach can achieve goals of creating affordability of space and diversity of use, while also creating a place of memory, creativity, pleasure, and sensorial dynamism which can foster imaginative production in the areas of play, arts, and craft.

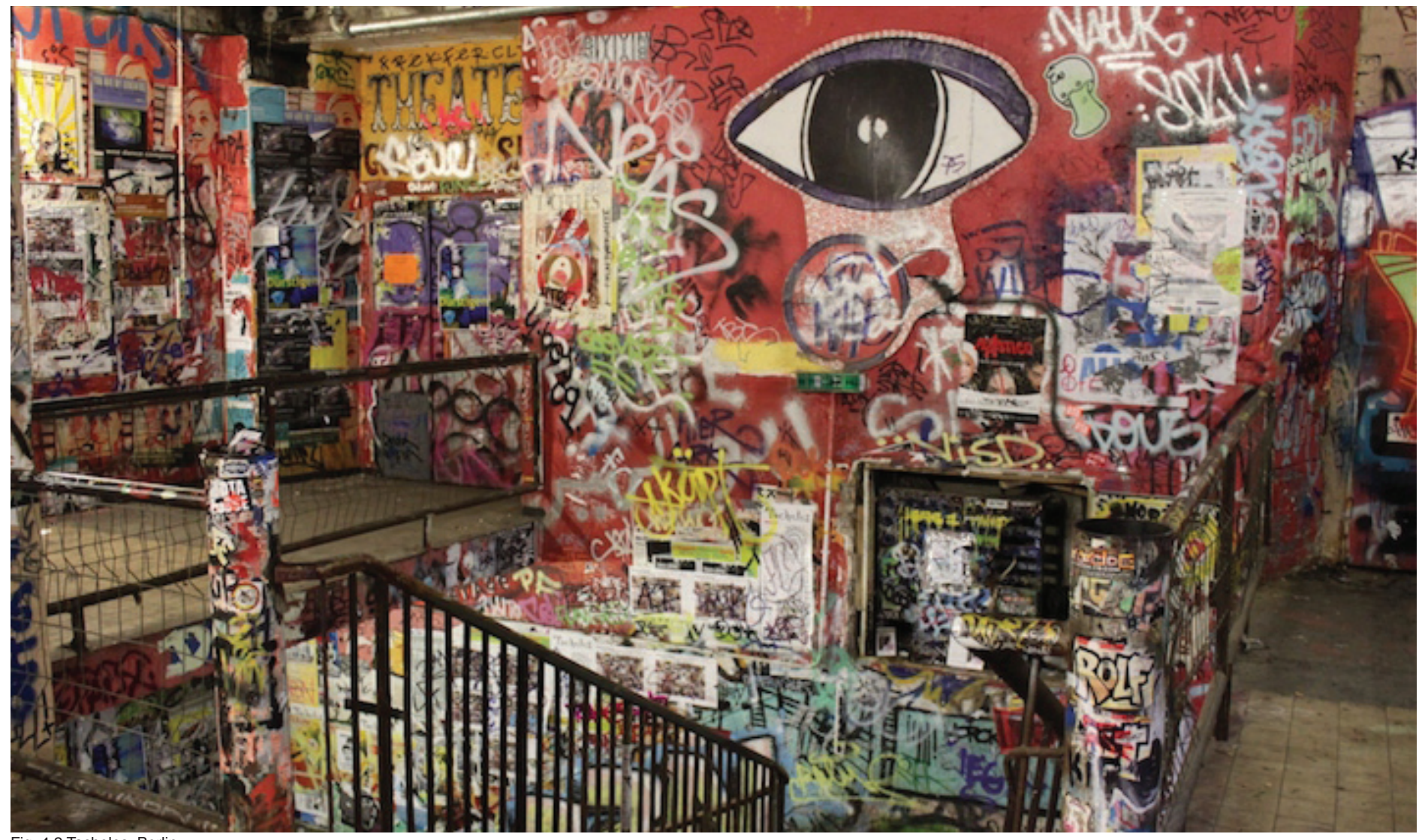

Fig. 4.2 Tacheles, Berlin 


\subsection{Abandoned Space Appropriation}

By reinterpreting, reusing, and re-purposing urban spaces and objects, the uses within these spaces, be them artistic, performative, or economic, can serve to redefine and improve blighted urban conditions. Many industrial urban spaces in the west, such as those that exist in Detroit, are left neglected and under-utilized due to loss of industry and the resulting unemployment, flight, and decay. Subsequently, it is often rather difficult to reinvigorate these areas, especially through the traditional capitalist avenues of attracting investment, when these spaces are perceived as 'dead' from an economic perspective. However, when these places start to attract investment from traditional avenues, a delicate balance needs to happen with regards to the prospective value of space, the needs of the community, and the proposed development or redevelopment of existing space.

Appropriating space for the production of artistic, performative, or craft based acts can be seen as a reinvestment in use value as opposed to exchange value wherein this delicate balancing act can be facilitated. Abandoned space appropriation can benefit the local community both by providing needed recreation space as well as space for knowledge and craft production. As Lefebvre states in Production of Space (1974):

"Through the production of space... living labor can produce something that is no longer a thing, nor simply a set of tools, nor simply a commodity.. needs and desires can reappear as such... spaces for play, spaces for enjoyment, architectures of wisdom or pleasure. In and by means of space, the work may shine through the product, use value may gain the upper hand over exchange value." (p.170)

To conceive of space as simply a place of commodity production is to prioritize profit and capital exchange, which by its nature ignores other forms of human expression and creative production, necessary to the well being and constructive growth of the surrounding community. Often, street subcultures such as graffiti writing, MCing and skateboarding are pushed to the margins of society, where they are see as outsider, anti-social forms of expression. In reality, they can be crucial to the development of critical thinking skills, creative forms or expression, personal confidence, and social skills.

Proposing a re-use strategy for abandoned industrial spaces for contemporary urban creative expressions and actions, such as those listed above, can serve to catalyze an interest and acceptance in street subcultures that are all too often marginalized from mainstream society.

"The shrinking city is also an incredible city, saturated with urban opportunities that are precluded or even unthinkable in cities that function according to plan. Taking advantage of these opportunities requires an approach to the shrinking city not so much as a problem to solve than as a prompt to new understandings of the city's spatial and cultural possibilities." (Herscher, 2012) 


\subsection{Pyschogeography as Design Strategy}

In 1957, philosopher Guy Debord, Dutch artist Agner Jorn and the post war French radical group the Situationist International proposed the idea of a psychogeographic (also called derive) map of Paris for their conceptual project titled the 'Naked City' (Debord,1957)(Fig. 4.3). The Naked City was, for the first time since the radical, city altering, modernist grid, a dramatic rethinking of the city as an abstract work of art which could be experienced not simply as a series of pre-determined built forms but of events. The map suggested that the citizens of Paris ought to experience the city as a series of random forms and places of potential radical behavior and events, where the rigid capital based consumer culture imposed (and reinforced by) the modernist grid could be subverted, and human life could be truly experienced. Debord explains that, during one of these psychogeographic journeys; "one or more persons during a certain period drop their usual motives for movement and action, their relations, their work and leisure activities, and let themselves be drawn by the attractions of the terrain and the encounters they find there." (Debord, 1958). By doing so, Debord argued, the city would become an evolving network of new possibilities, where instructions and directions were unnecessary, where agency could be truly experienced, and where the future could be derived through visceral experience.

In addition to Debord and Jorn, post-war avant guard architects such as Aldo Van Eyck and Constant Nieuwenhuys (also a founder of the Situationist International) were engaged in post-modernist ideological explorations into architecture. As Van Eyck observed: "Instead of the inconvenience of filth and confusion, we have now got the boredom of hygiene... mile upon mile of organized nowhere" (Sadler, 1999, p.32).

Constant Nieuwenhuys' 'New Babylon' project, started in 1961 (Fig. 4.4) was conceived of in a never ending series of abstract sketches, paintings, and models which were meant to convey a city that had no beginning and no end; where social hierarchies, centralized governments and national economies did not exist; and that which gave users freedom of choice in the use and discovery of its spaces and places.

The rigid structural grid of the of the early 20th century factory building provides an ideal setting to employ, as a design intervention, the ideological and physical framework presented by Debord and Jorn's Naked City and Nieuwenhuys' New Babylon. By encouraging random movement and discovery throughout the plan of the building, the building itself becomes an evolving network of random events and experiences. This will be achieved by presenting the plan of the building as a semi-random matrix, where users are encouraged to discover different programmatic elements at whim. Not only will this strategy promote diversity of experience and encourage random creative activity and play, but it will also help to inform future bottom-up design strategies for the portions of the building that have been left programmatically undetermined. 


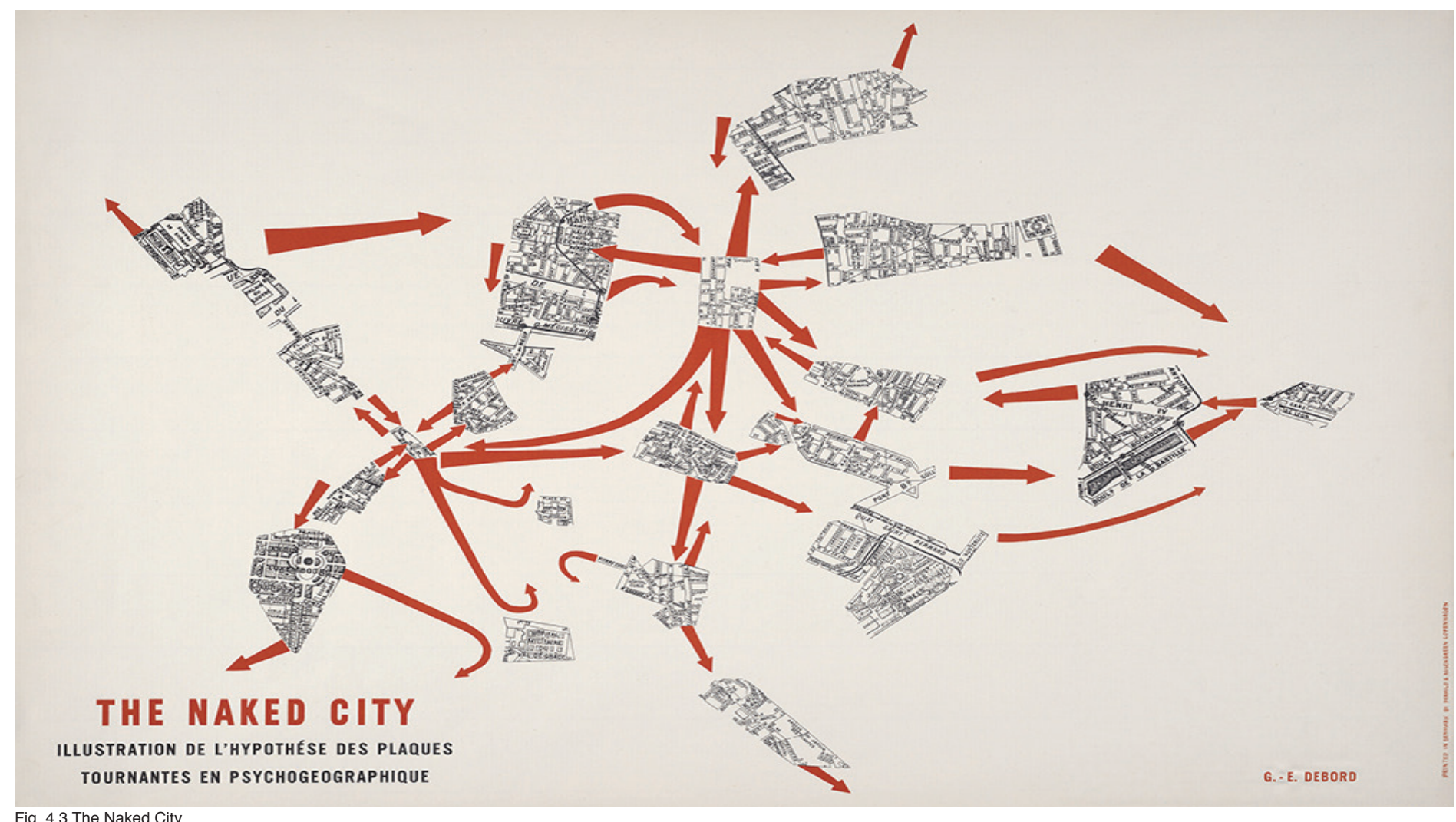

Fig. 4.3 The Naked City

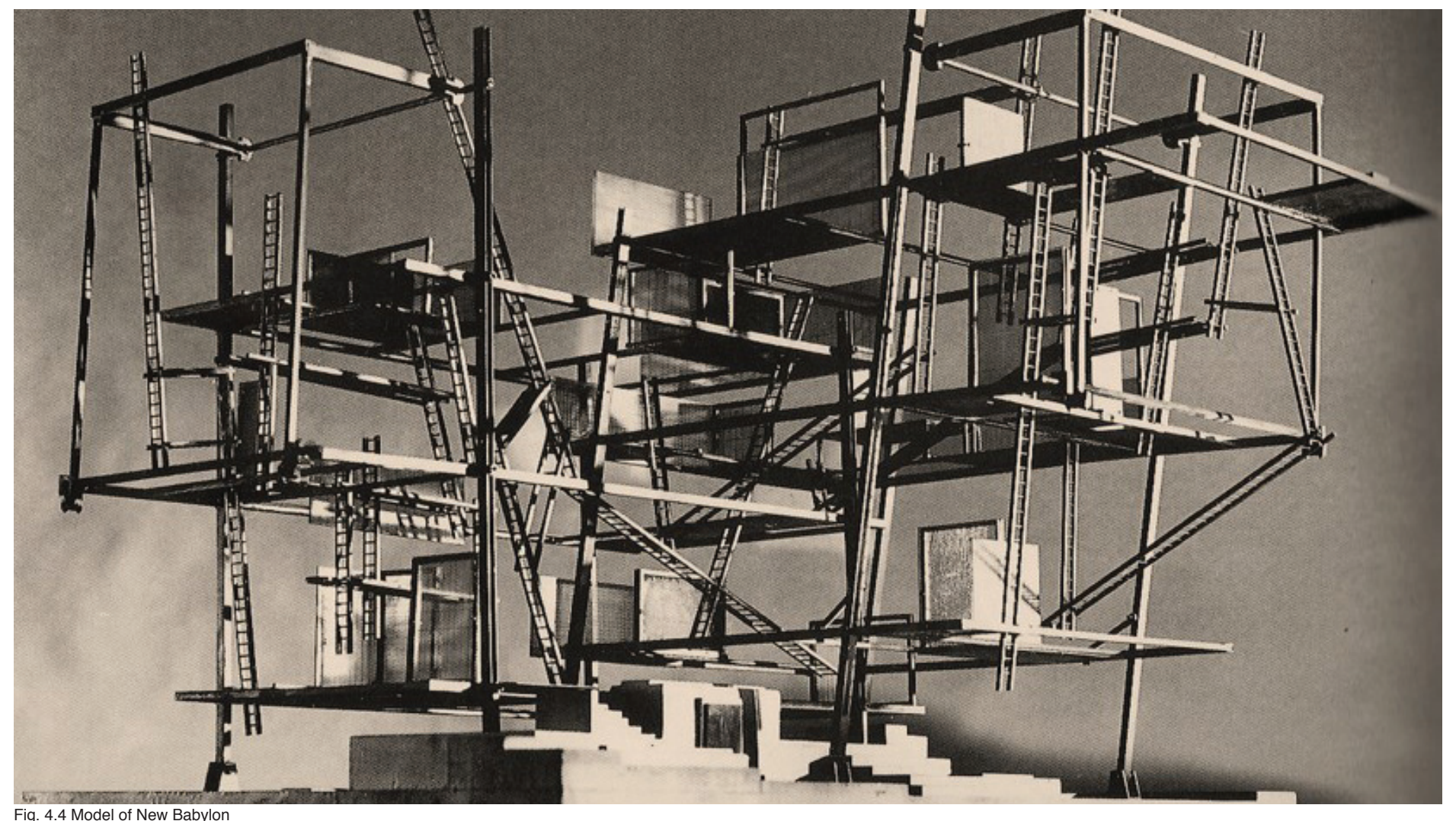

Fig. 4.4 Model of New Babylon 


\subsection{Design Research}

The following images present a series of explorations into the deconstruction of a typical early 20th century industrial structure. The re-appropriation of static, uniform, deterministic images in to disordered, de-constructed, abstracted and dynamic forms has helped to inform a potential design strategy.

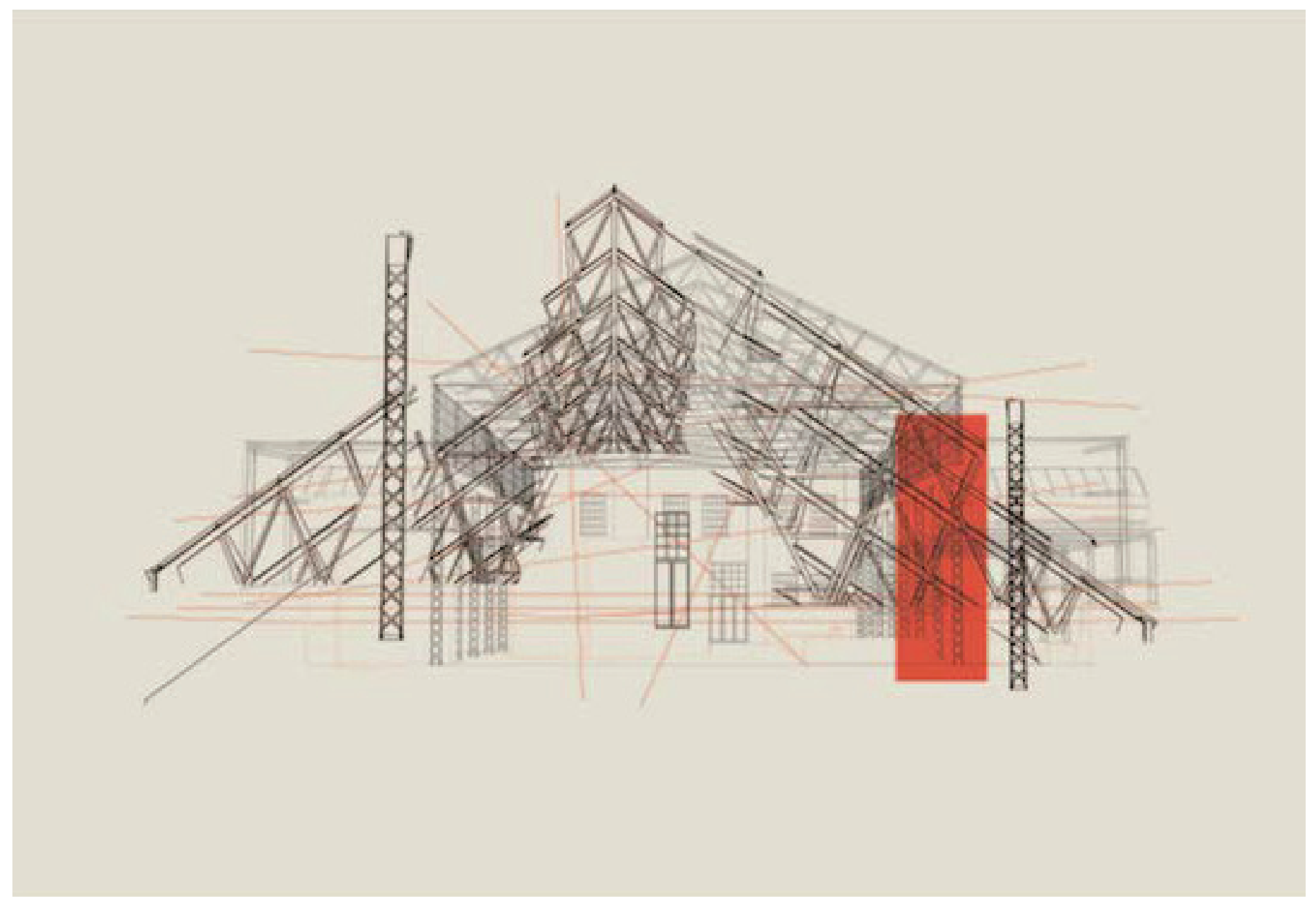

Fig. 4.3 Deconstruction Exploration 1 


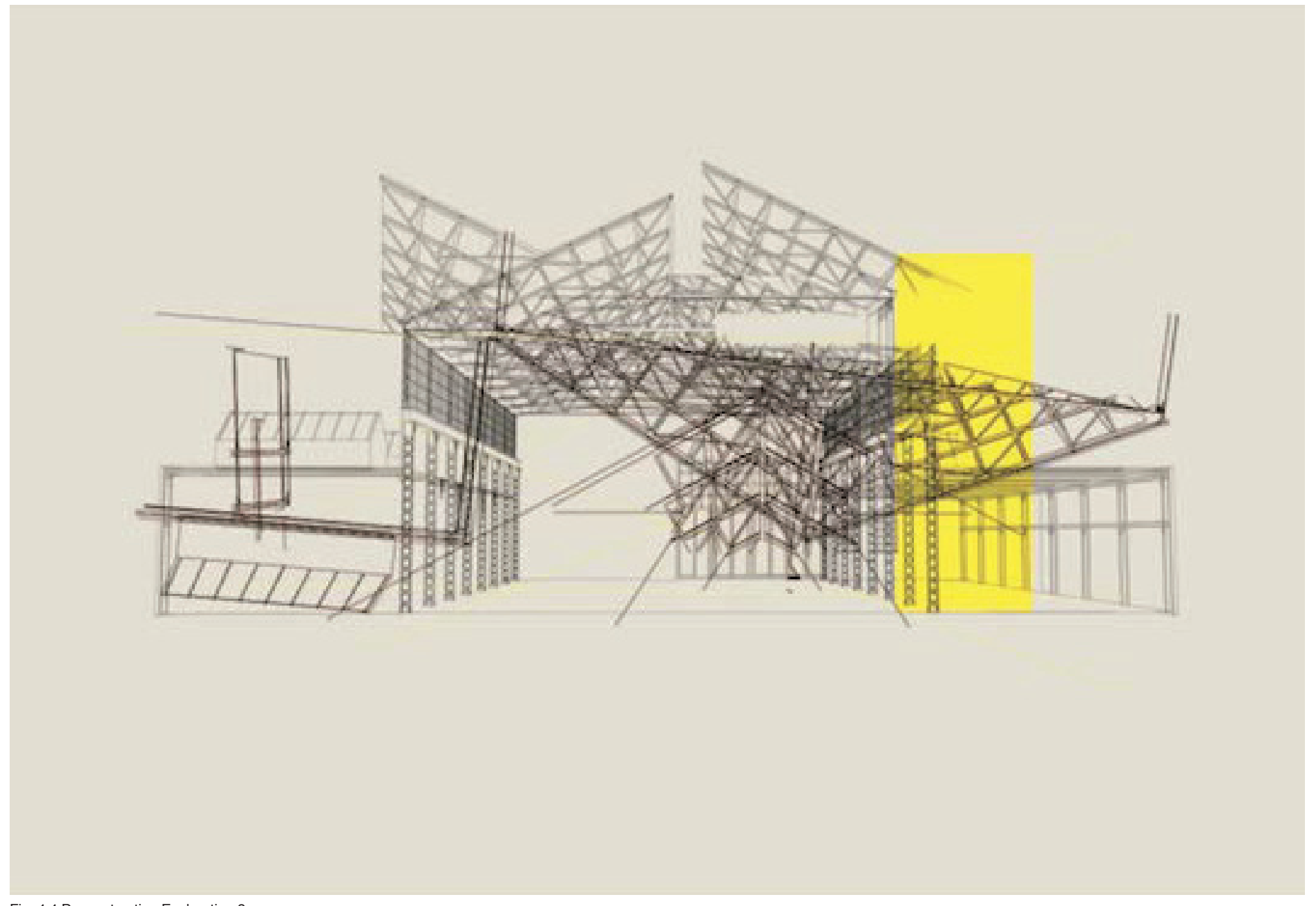

Fig. 4.4 Deconstruction Exploration 2 


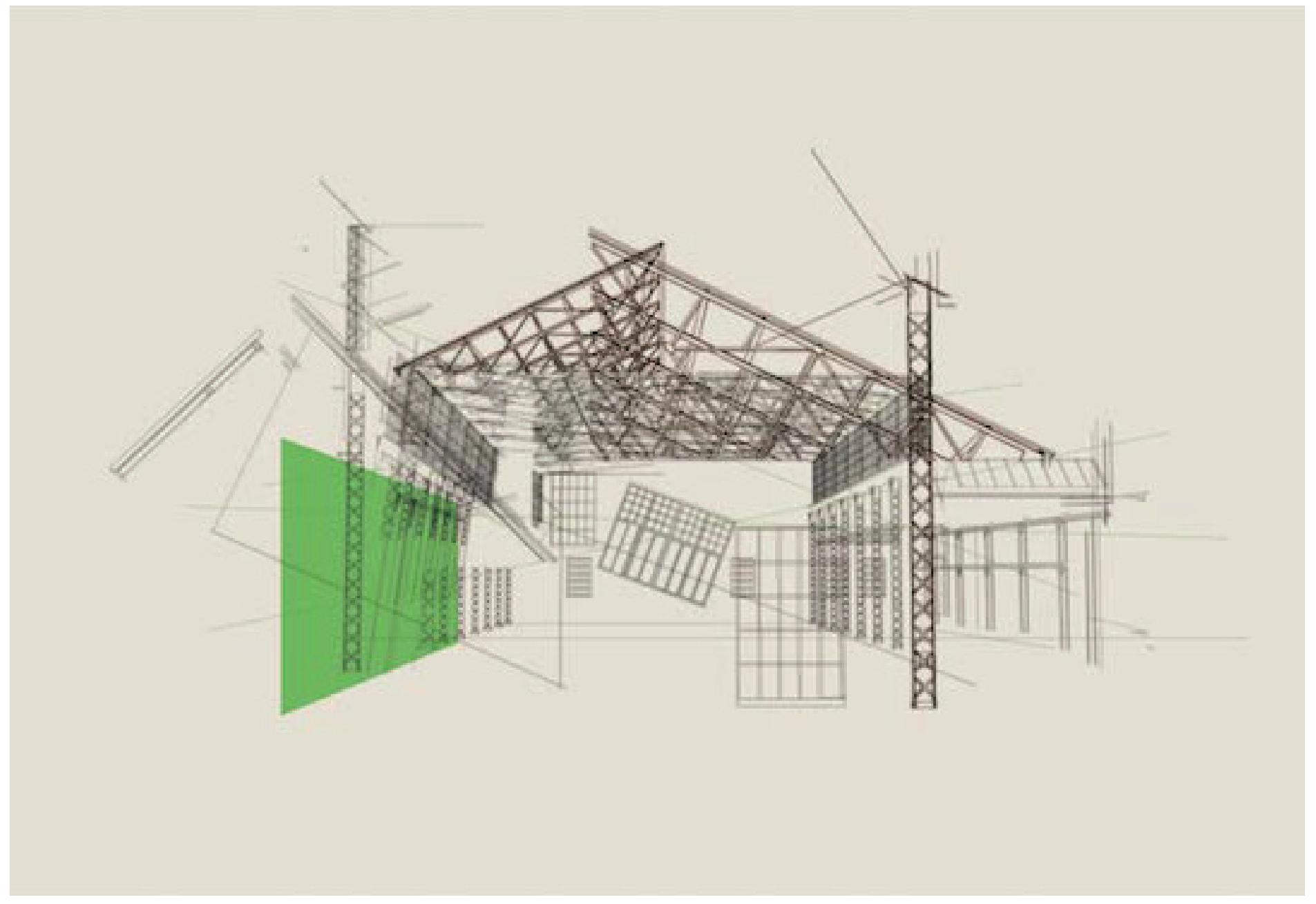

Fig. 4.5 Deconstruction Exploration 3 


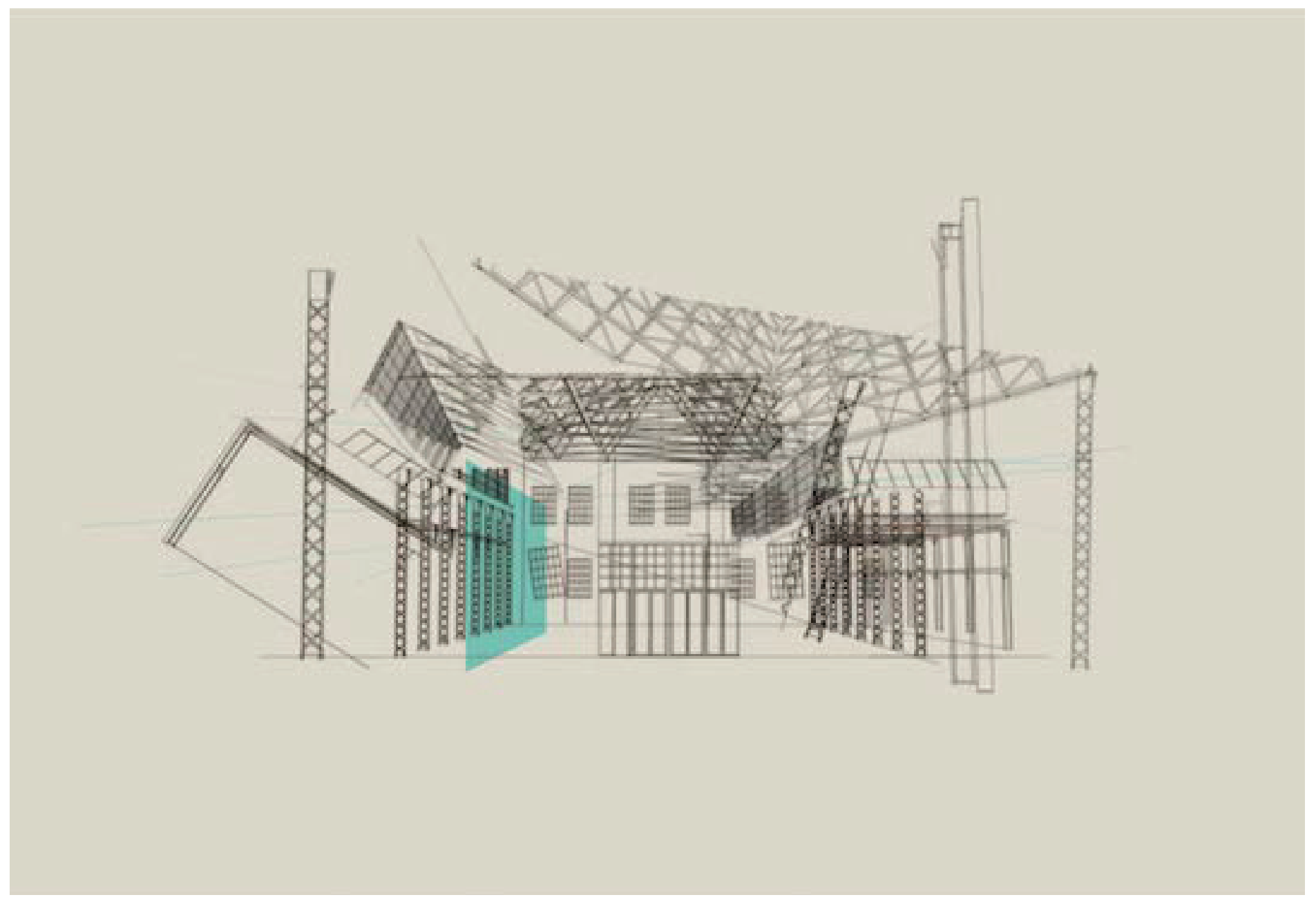

Fig. 4.6 Deconstruction Exploration 4 


\section{Chapter 5 - Development Without Gentrification}

\subsection{NGO's, Land Banks, Community Trusts etc.}

In recent years, Detroit has seen an influx of private investment towards infrastructure projects within the city. Much of this investment has been spearheaded by Billionaire businessman Dan Gilbert, Detroit resident and founder of Quicken Loans. Gilbert has been instrumental in revitalizing the city's core, and has been heavily involved in the purchasing and revitalizing of historic properties, as well as removing dangerously blighted properties in the city. Gilbert has also been instrumental in the development of public infrastructure projects such as the Qline, and public park revitalization.

However, New urban investments in a community, such as improved transit, new public parks, or new mixed-use developments, can signal to investors and developers that an existing community is increasing in value. The effect of such investments is often displacement of existing businesses and residents through higher rents, higher property taxes, and the redevelopment of housing. It can also rapidly change an existing community's character, so that residents feel like outsiders in the spaces they have long occupied.

The process of gentrification can be countered in a number of ways through alternate economic approaches to the funding of new development.

None of the following options are a complete solution, but they can contribute to ensuring that, rather than displacing existing residents of a community, new investment can make life better for them, possibly while also integrating new members into an existing community:

\section{NGO's}

A non-governmental organization (NGO) is a non-profit, citizen-based group that functions independently of government. NGO's, sometimes called civil societies, are organized on community, national and international levels to serve specific social or political purposes, and are cooperative, rather than commercial, in nature. NGO can be funded in a variety of ways including: membership dues, private donations, the sale of goods and services, and government grants.

\section{Community Co-Development}

In a Community Co-development, the community itself comes up with initiatives that suit its own needs, and the implementation of their initiatives is supported by funding and expert advice rather than being led by it. That can mean that the community develops in ways that reinforce its own needs, rather than being reshaped by a generic template that attracts wealthier outsiders. 
Private Public Partnerships

Private Public Partnerships is a mechanism that can be used by governments to deliver public infrastructure and public services using the resources and expertise of the private sector. Often PPP's are used to fund early phases of a re-development project to mitigate risk involved in project phases such as heritage preservation, site remediation and environmental improvement, public transport and mobility, and water management.

Community organizing

Community organizing generally refers to a community consultation process whereby the organized local community advocates for its own needs and establishes co-development opportunities that reinforce the community, that develop affordable housing, and that generate a cultural identification with substance. This involves city planners, investors, and consultants, along with the local community, organize meetings, go door to door, and set up community consultation pop-ups.

\section{Land banking}

Land banking purchases land before it becomes egregiously expensive and sets it aside for affordable uses for the existing community. Land banking can go beyond affordable housing to think of affordable communities - places where those in affordable housing also have services and amenities that suit their income level. As such, land banking can be for affordable housing, shelters, seniors housing, non-profit services, educational classrooms, youth community centers, artist studios, or co-op, independent, or affordable retail. 
Chapter 6 - Site: Albert Kahn's Fisher Body Plant \#21

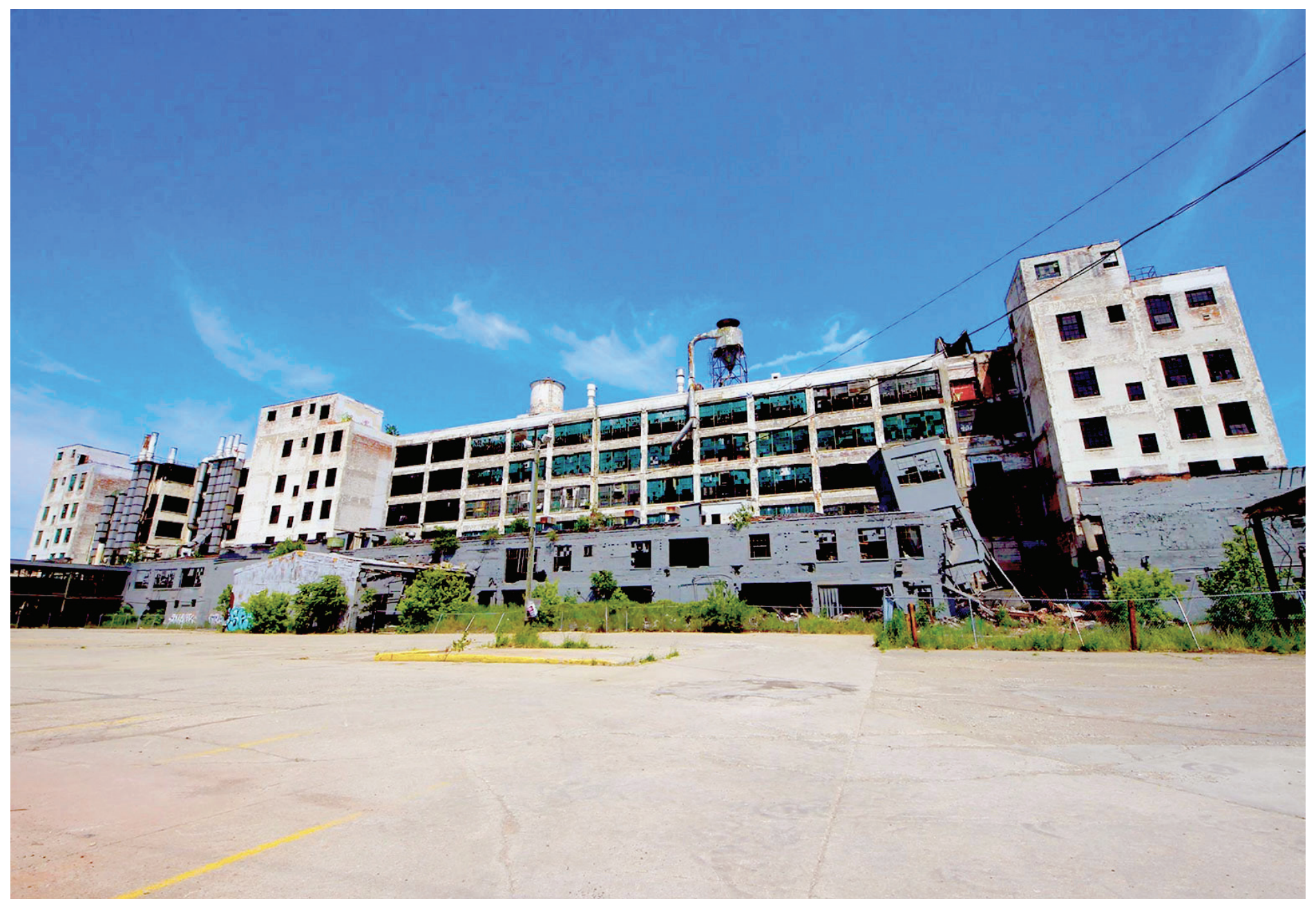

Fig. 6.1 Fisher Body \#21 


\subsection{Site History}

The Fisher Body Company was formed in 1908 in Cleveland Ohio by Albert Fisher and his nephews Charles and Fred. Fisher Body Co. initially produced bodies for both the carriage and automotive industries, although they dropped the carriage line in 1911. At the time, auto bodies were made of a mixture of shaped wood and metal, and their construction was a complicated process requiring skilled tradesmen. As a result, auto-makers found it was more cost-effective to outsource the construction of auto bodies to third part manufacturers. As a result, by the early 1910's Fisher Body Co. was producing high-quality automotive bodies for Cadillac, Ford, Studebaker, and Hudson, among others

The 1910's were a period of rapid growth for the Fisher Body Co. as the advent of the assembly line meant that cars such as the Model T were being produced at an unprecedented rate. To meet increasing demand, Fisher expanded its operations to over 40 plants in Detroit, Cleveland, Flint, and Windsor, Ontario. Fisher Body plant \#21 was built in 1919 on Piquette Street in the Milwaukee Junction neighborhood of Detroit's North End, just about a block and a half away from Henry Ford's original Piquette Ave. plant. The six-story building was designed by Albert Kahn, and features reinforced concrete construction, and walls of industrial sash windows to allow in plenty of natural light.

General Motors had moved most of its bodywork to Fisher in 1917, and two years later bought a controlling interest in the company. The two companies merged in 1926, although the "Body By Fisher" slogan continued on. With the proceeds from the merger, the Fisher brothers built their landmark 30-story art deco headquarters (also designed by Kahn) across from the General Motors Building on West Grand Boulevard, about a 10 minute walk from the Body \#21 plant.

Like other automotive companies, Fisher retooled during the Second World War for military production, manufacturing components for planes, anti-aircraft guns, tanks, other materials for the war effort.

In November of 1982 General Motors announced it was closing the \#21 body plant and moving limousine production to Flint. The last day of production was April Fool's Day, 1984 (Detroiturbex).

Fisher Body \#21 is located within Detroit's 'Piquette Avenue Historic District' which was listed on the National Register of Historic Places in 2004. The Studebaker factory on Piquette has since been demolished, but the Ford Piquette Plant remains and is open to the public as a Ford museum. 


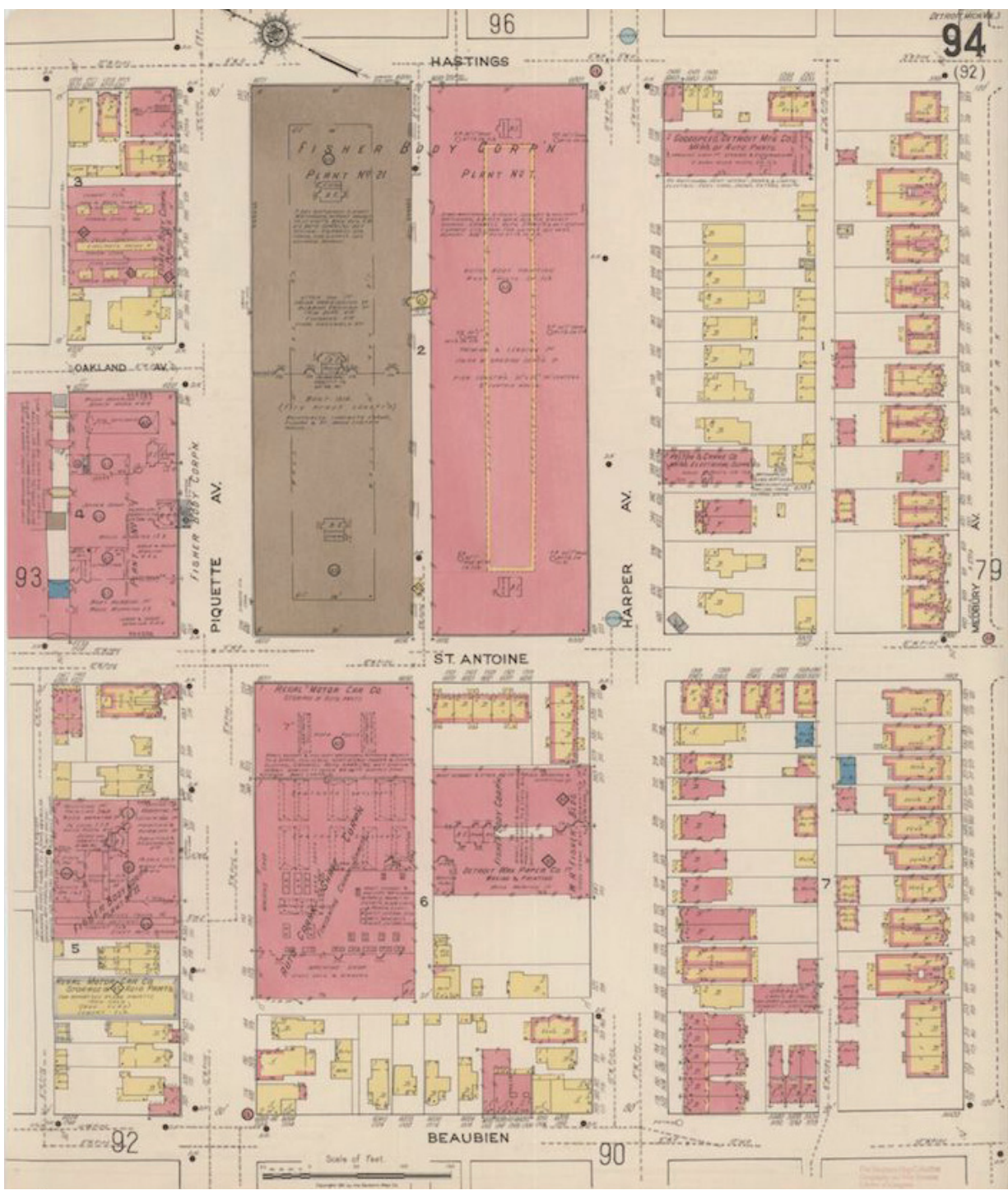

Fig. 6.21921 Fire Map. Fisher Body 21 hatched in brown.

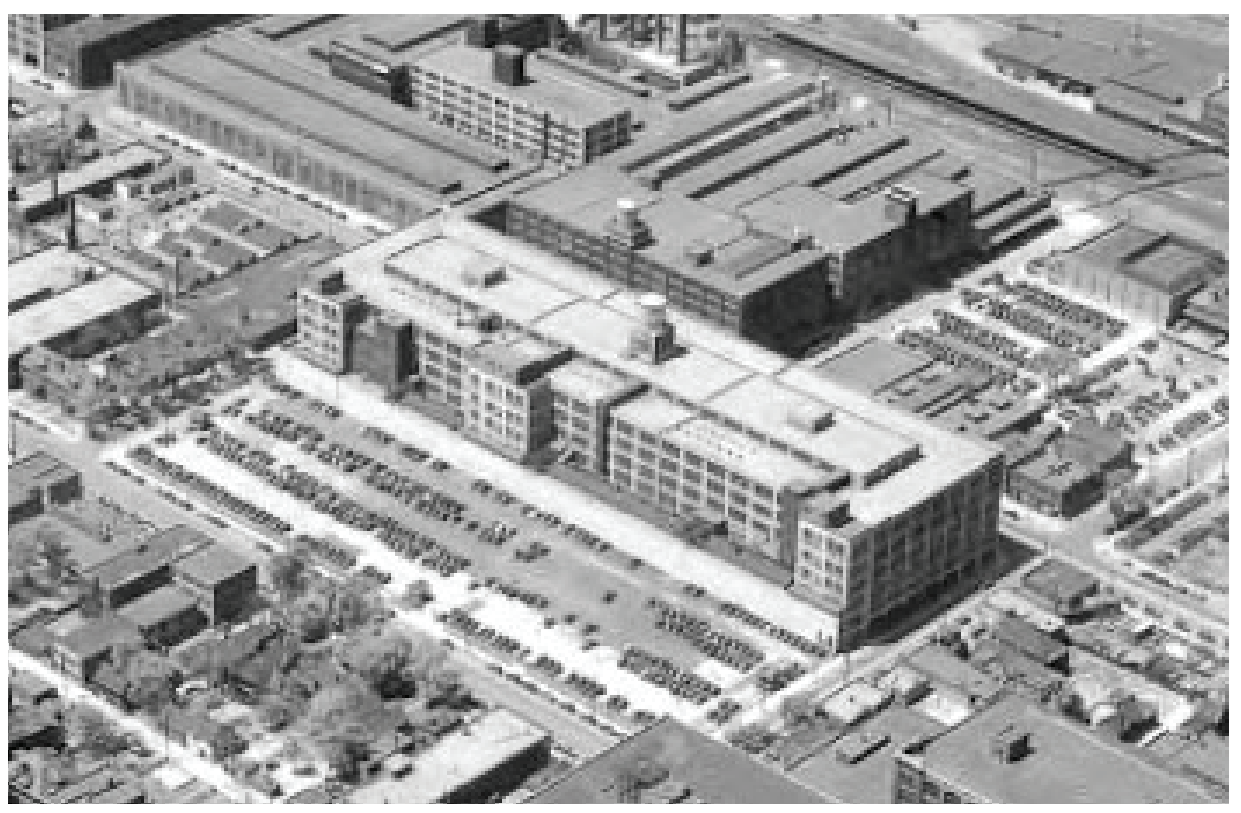

Fig. 6.3 Historic aerial photograph of Fisher Body \#21 in the 1920's 


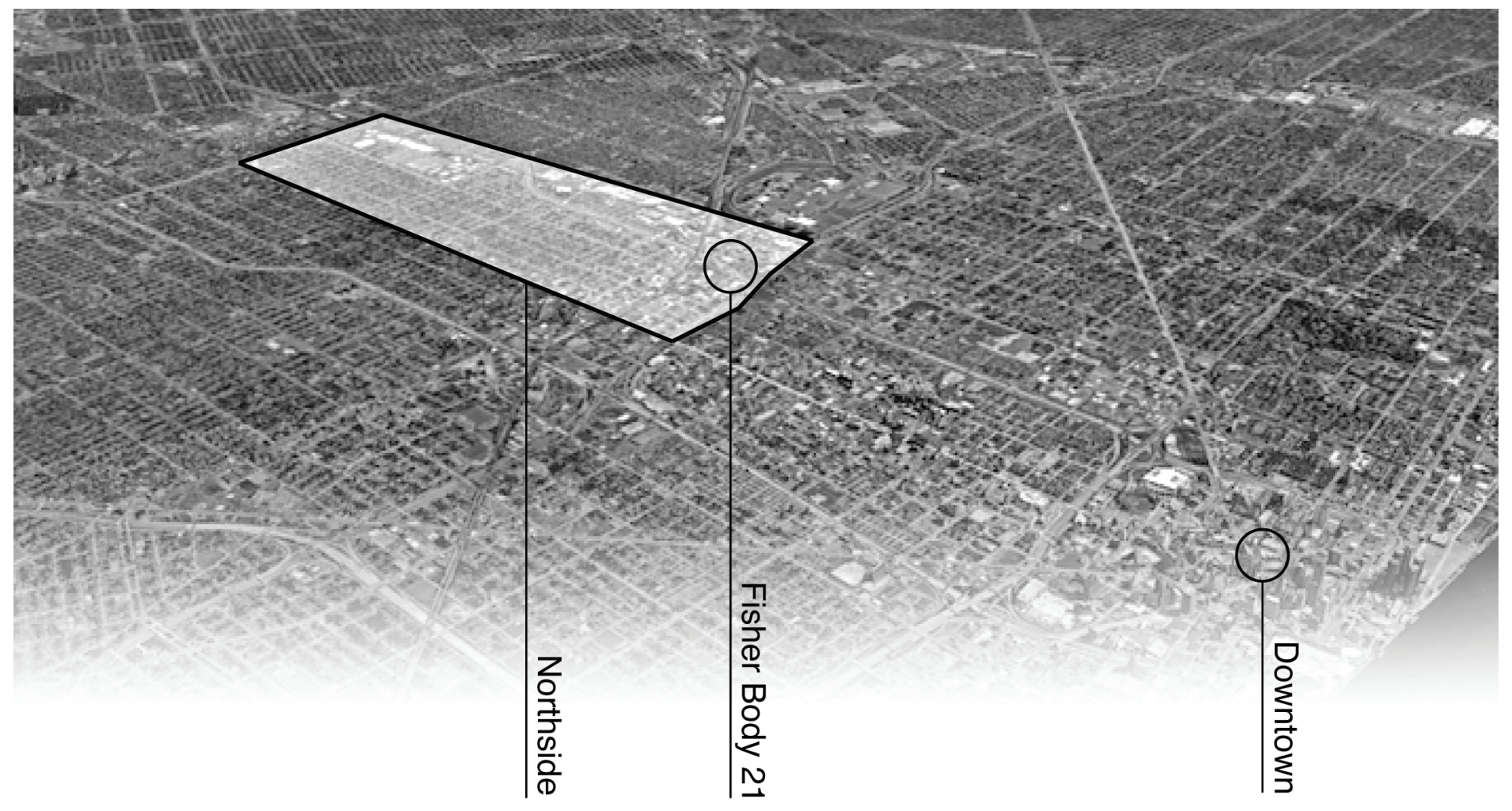

Fig. 6.4 Aerial Diagram. North End Hatched in White

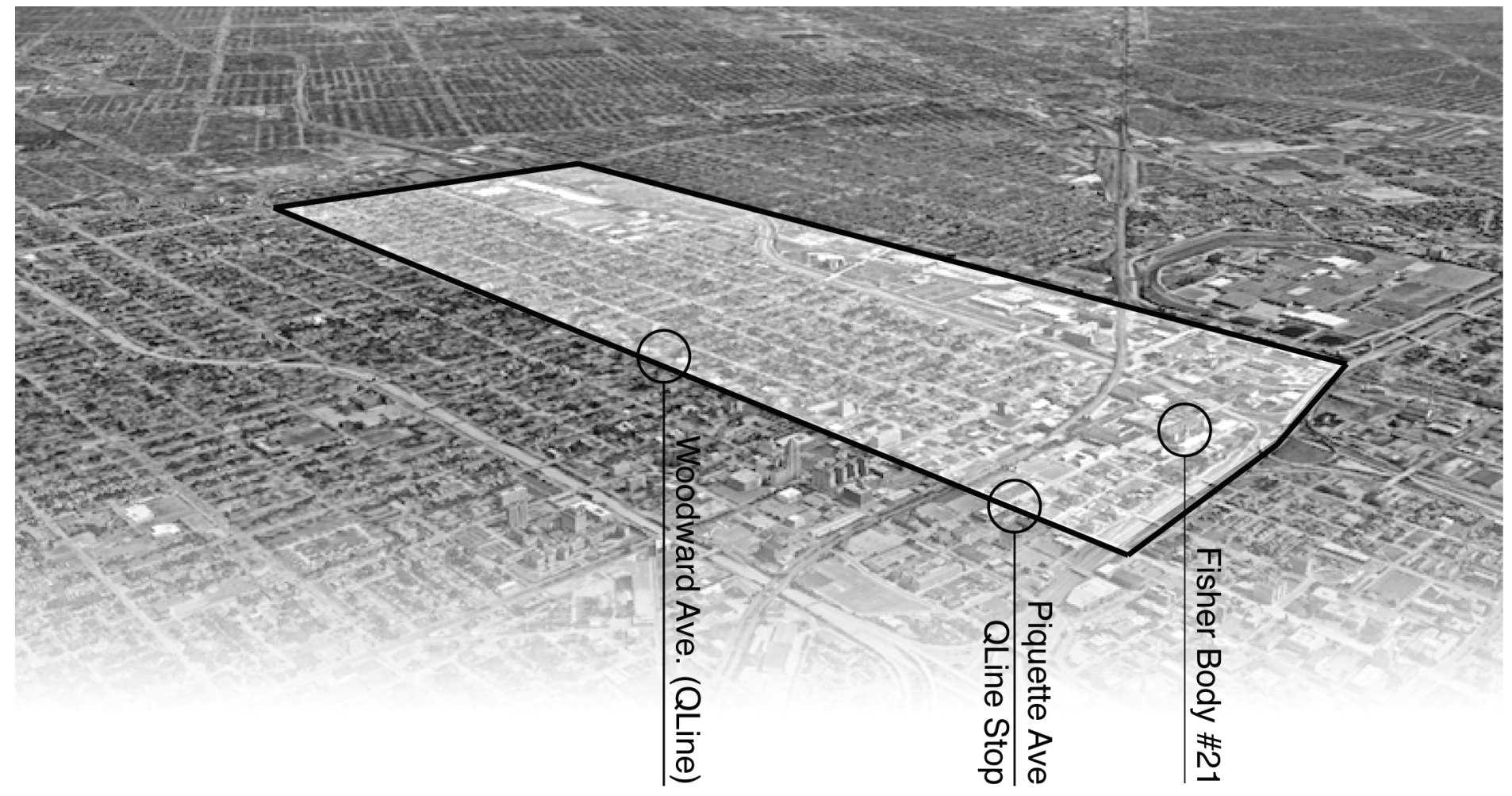

Fig. 6.5 North End Aerial Diagram 


\subsection{Site Context}

Towards the end of the 19th century, Detroit's industrial growth was primarily located around the rail lines that ran around what was then the city periphery. This location, also known colloquially as the North End, provided factories easy access to the rail network while at the same time keeping them somewhat isolated from the city's core. The intersection of the Detroit, Grand Haven, and Milwaukee Railway, as well as the Chicago, Detroit, and Canadian Grand Trunk Railroad provided a name for the new neighborhood now known as the Milwaukee Junction. The convenience of the location meant that automotive companies flocked to the area, with Ford, Fisher Body, and Studebaker being among the first to establish operations. As these companies set up sales and production facilities in the area through the early part of the 20th century, the Milwaukee Junction became the primary hub for the automobile industry in the city of Detroit, and thus, the country.

The area to the north of the Milwaukee Junction was where the majority of the residential infrastructure was built to house the labourers of Milwaukee Junction's industry. At its peak in 1950, the North End was home to 51,709 residents which has shrunk to just 5,185 as of the 2010 census. In that same census, it was recognized that $94 \%$ of residents were African American, although over the last 8 years, the neighborhood has seen an influx of younger, more affluent whites.

As Identified in the report titled 'History's Future in the North End', despite the North End's high vacancy rates, "much of the housing remains in good condition. The 2009 Detroit Residential Parcel Survey assessed housing conditions throughout Detroit, including 1,943 residential structures in the North

End. This survey found that 1,660 of the houses in the district were in "good" or "fair" condition. (2013) (Fig. 6.7).

The North End's unemployment rate remains well above the national average, at $25-30 \%$, and the median household income hovers around \$25,000. As 'History's Future in the North End' Identifies, "New opportunities for jobs in the North End could reduce the North End's high unemployment rate and raise the median household income."

Despite the loss of the majority of the industrial activity, Milwaukee Junction maintains some of its automotive and industrial past. For example, New Center Stamping, founded in 1989 and located a 5 minute walk from Fisher 21, provides stamped components and welded assemblies for clients including Ford, General Motors, and Mazda. There have also been a number of new companies making use of older abandoned Industrial properties, such Detroit Soup using the Jam Handy Building, and The Russell Industrial Center providing space for artists, designers and small manufacturers. 

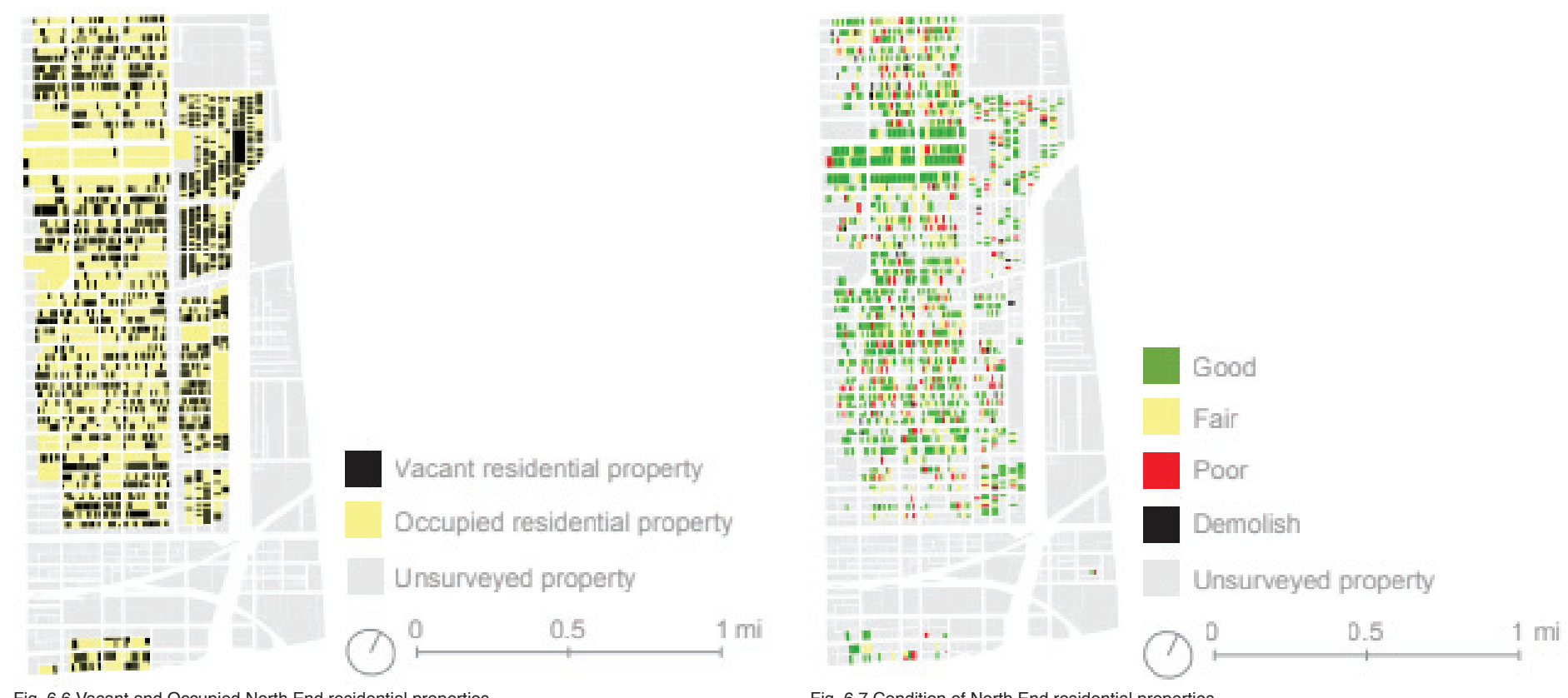

Fig. 6.6 Vacant and Occupied North End residential properties

Fig. 6.7 Condition of North End residential properties

While abundant physical space exists for new residents and entrepreneurs, the North End lacks many amenities to attract residents and visitors. For example, the North End has only one functioning grocery store, and only a handful of restaurants, most of which are fast food. Additionally, the North end lacks public green space, with only two small public parks located in the neighborhood. Further, the North End does not currently have a middle school or high school, with students being bused to other areas of the city to attend such institutions. Lastly, the North End currently lacks a public library, limiting residents' access to information, technology, and cultural/educational programs. The deficit of neighborhood amenities could help to inform part of the strategy for programming of the adaptive reuse proposal.

Despite the challenges that the North End neighborhood faces, there are also a number of benefits to the North End and Milwaukee Junction location of the Fisher Body \#21 building. First, the 2017 opening of the QLine light rail transit line along Woodward Avenue has made the site and neighborhood more accessible, and the Piquette Avenue stop of the $Q$ Line is just a 5 minute walk from the Fisher building. Further the site is within walking distance from a number of cultural amenities such as the Motown Museum, the Fisher Building, the Fisher Theater, Wayne State University, the Detroit Institute of the Arts, and the Fox Theater, among many others (Fig. 6.8). The rooftop of the Body 21 building also provides panoramic views of the surrounding area and of Downtown Detroit. 


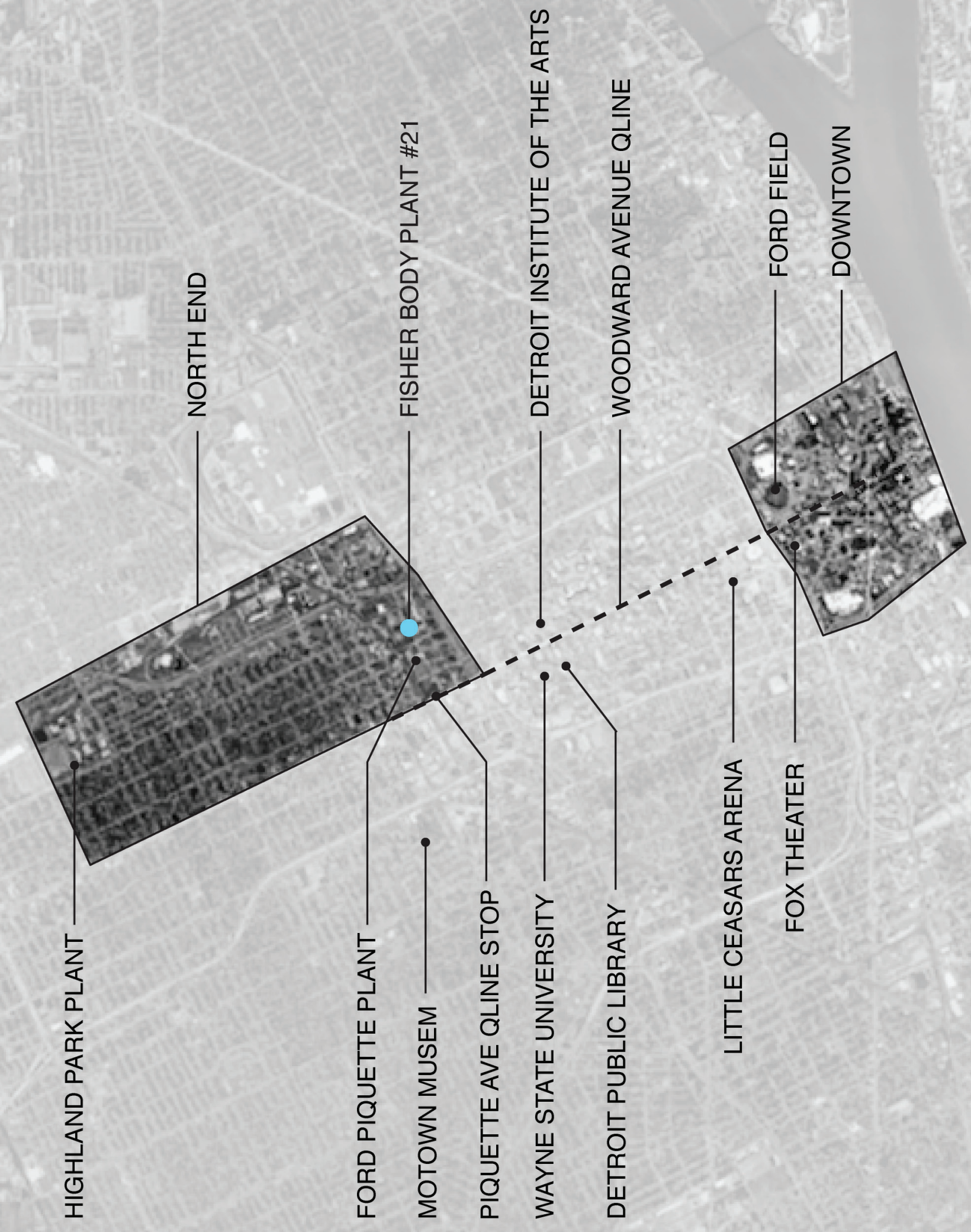




\subsection{Building Information}

The Fisher Body \#21 building is a 6 story reinforced concrete building, which has a gross floor area of approximately 450,000 sqft. The building is rectangular in plan, and has a 19 foot square bay grid system, with 26 bays lining Piquette Ave, and 6 bays lining Hastings and St. Antoine streets. The floor to ceiling height measures $14 \mathrm{ft}$ on the fist floor, as $12 \mathrm{ft}$ on all subsequent floors. A 2004 survey by the Michigan Department of Environmental Quality found "asbestos materials, lead waste, industrial equipment, storage tanks, other solid / hazardous debris and wastes, and contaminated soils and concrete" in and around the plant.

Due to hazards associated with the site for the surrounding residents, the Environmental Protection Agency began remediation work on the site in 2008, removing and disposing of large quantities of soil and contaminated equipment. The wooden bricks that had covered the floors were removed, as well as sections of concrete. In 2010, further work was undertaken to remove underground storage tanks.

Today, the building remains relatively intact, and much of the building is structurally sound. Despite scrappers removing every bit if steel from the building over the years, approximately $50 \%$ of the windows still remain, and the large mushroom shaped concrete columns provide a wonderfully dynamic interior. However, a fire in 2016 damaged a portion of the south side of the building, causing a portion of the second floor to collapse (Fig. 6.14). 

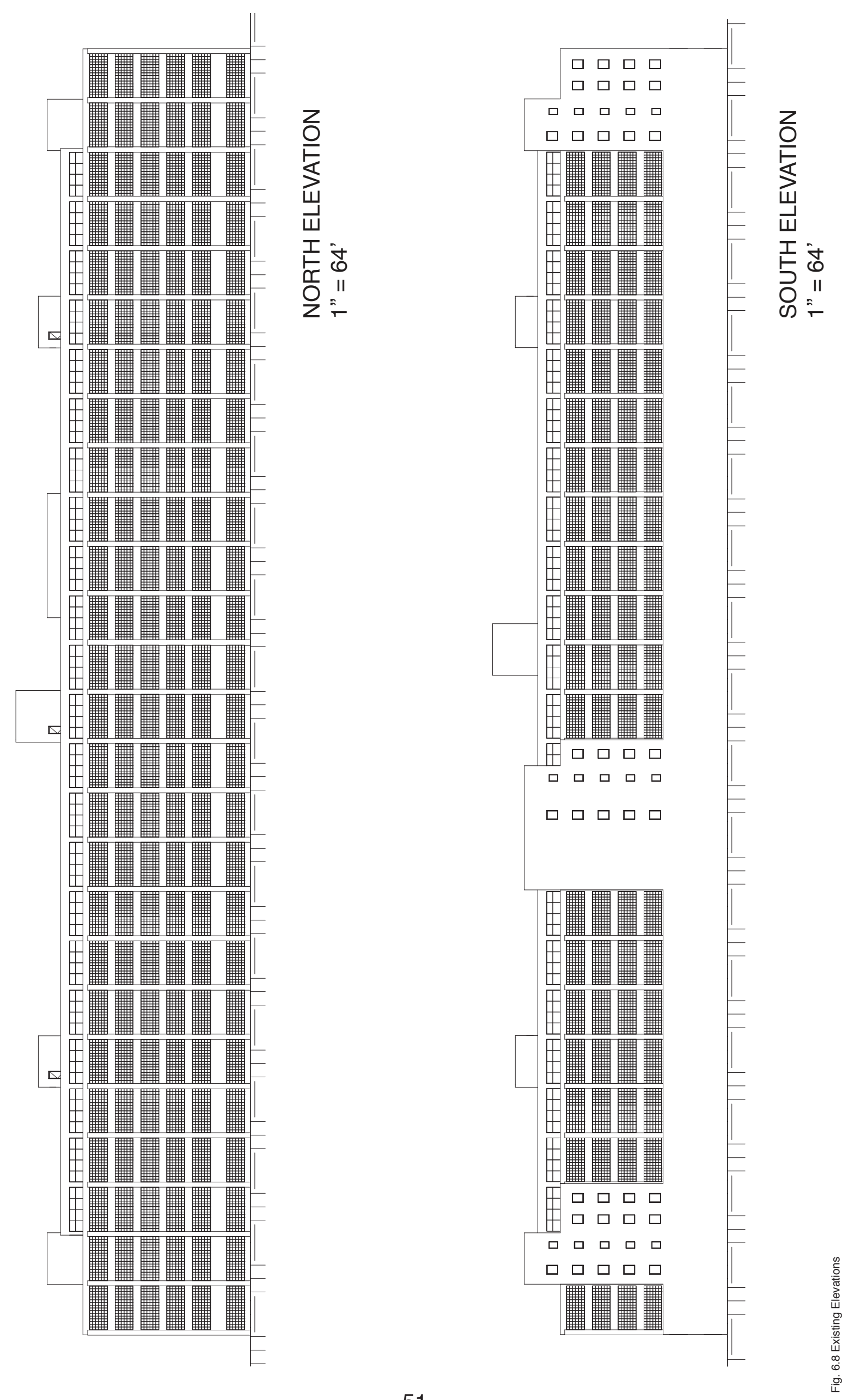

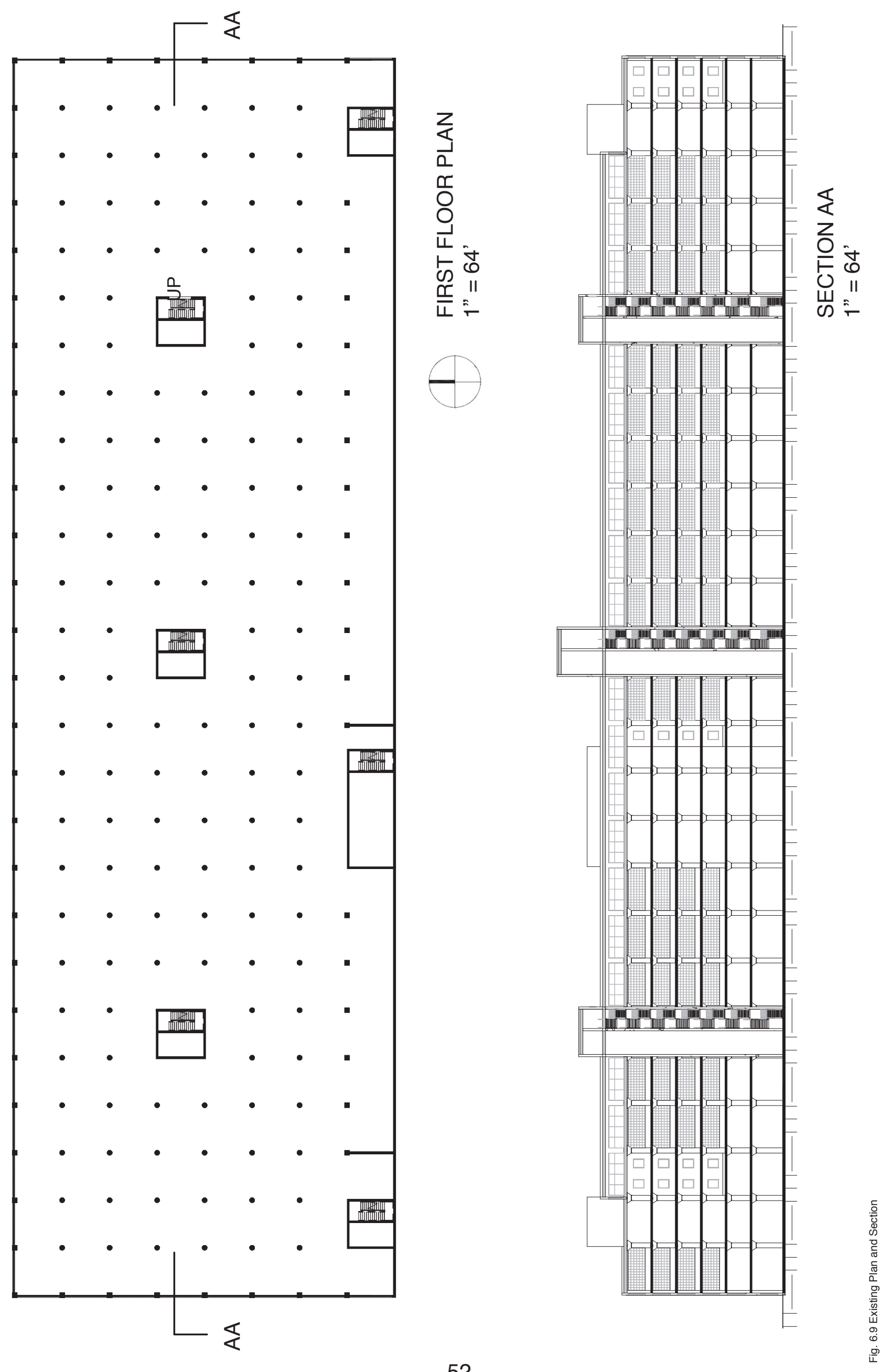


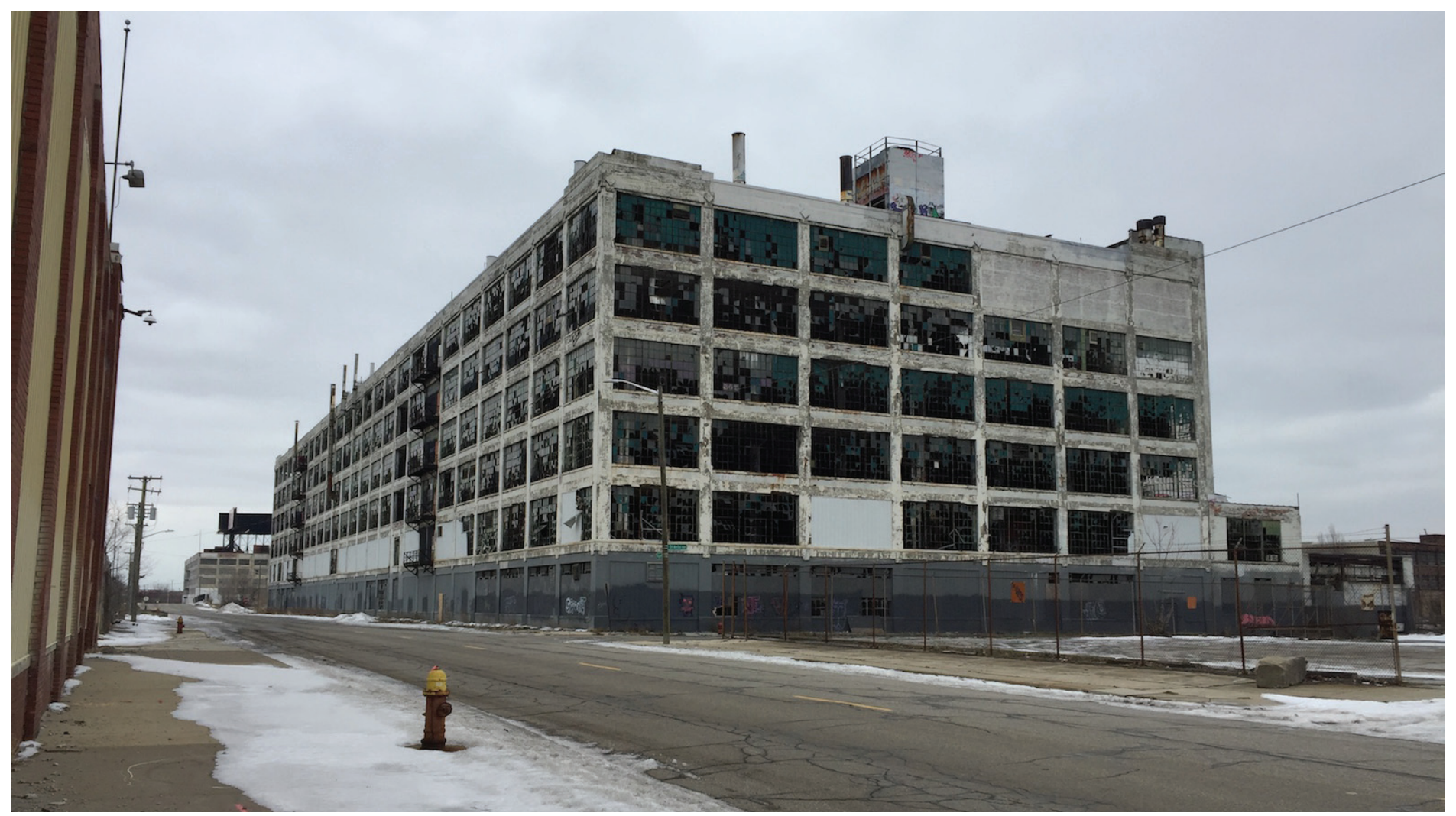

Fig. 6.10 Fisher Body \#21

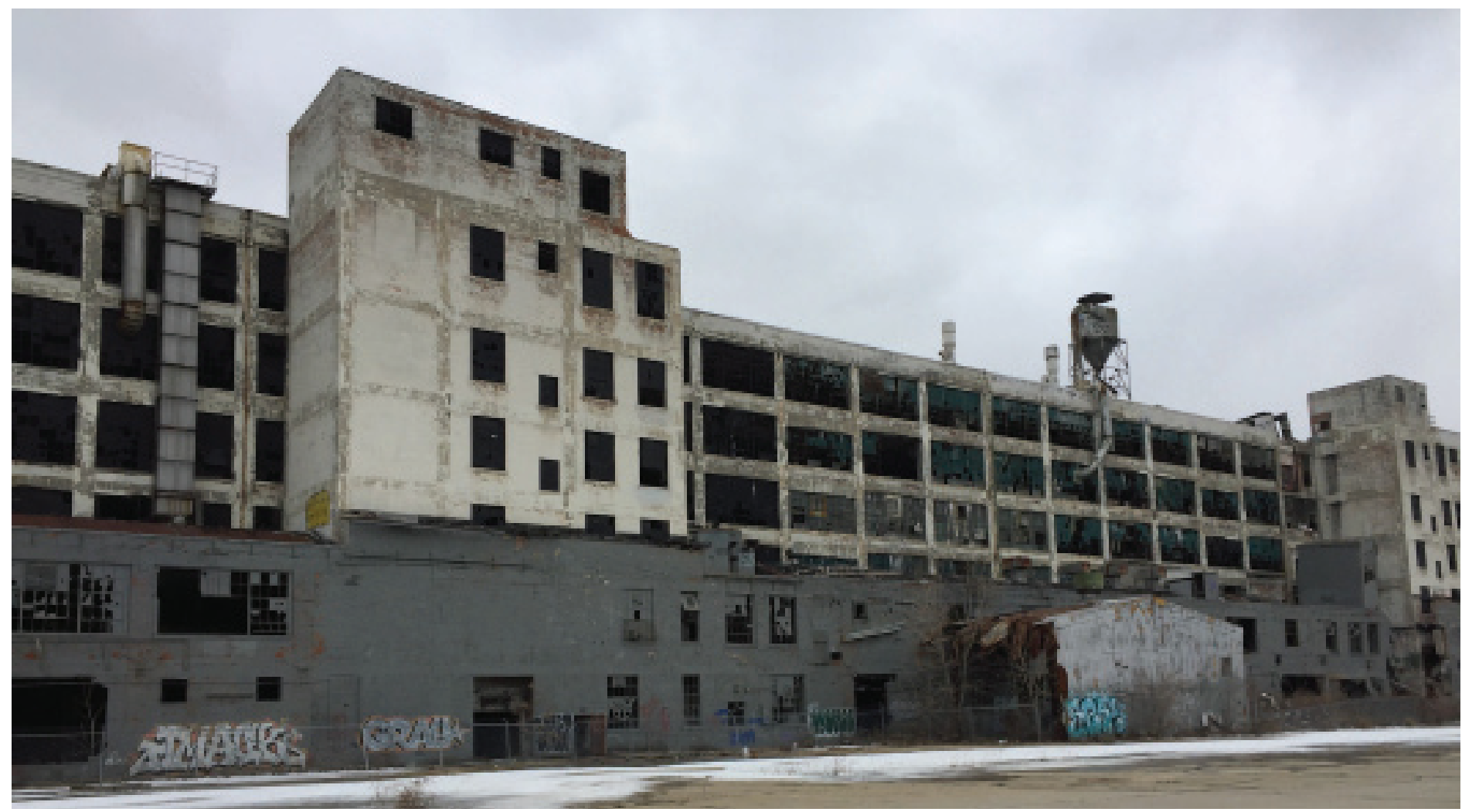

Fig. 6.11 Fisher Body \#21 

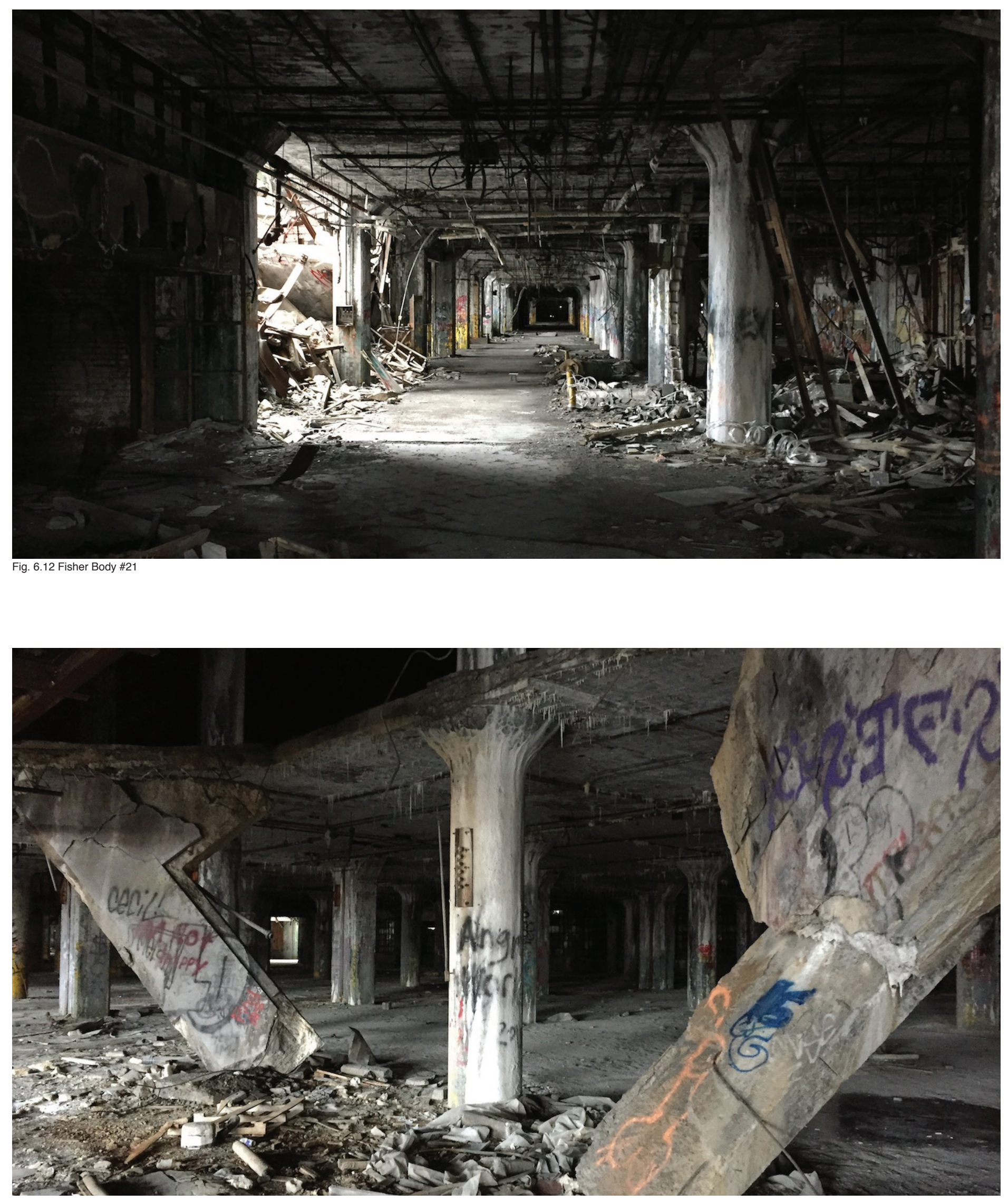

Fig. 6.13 Fisher Body \#21 

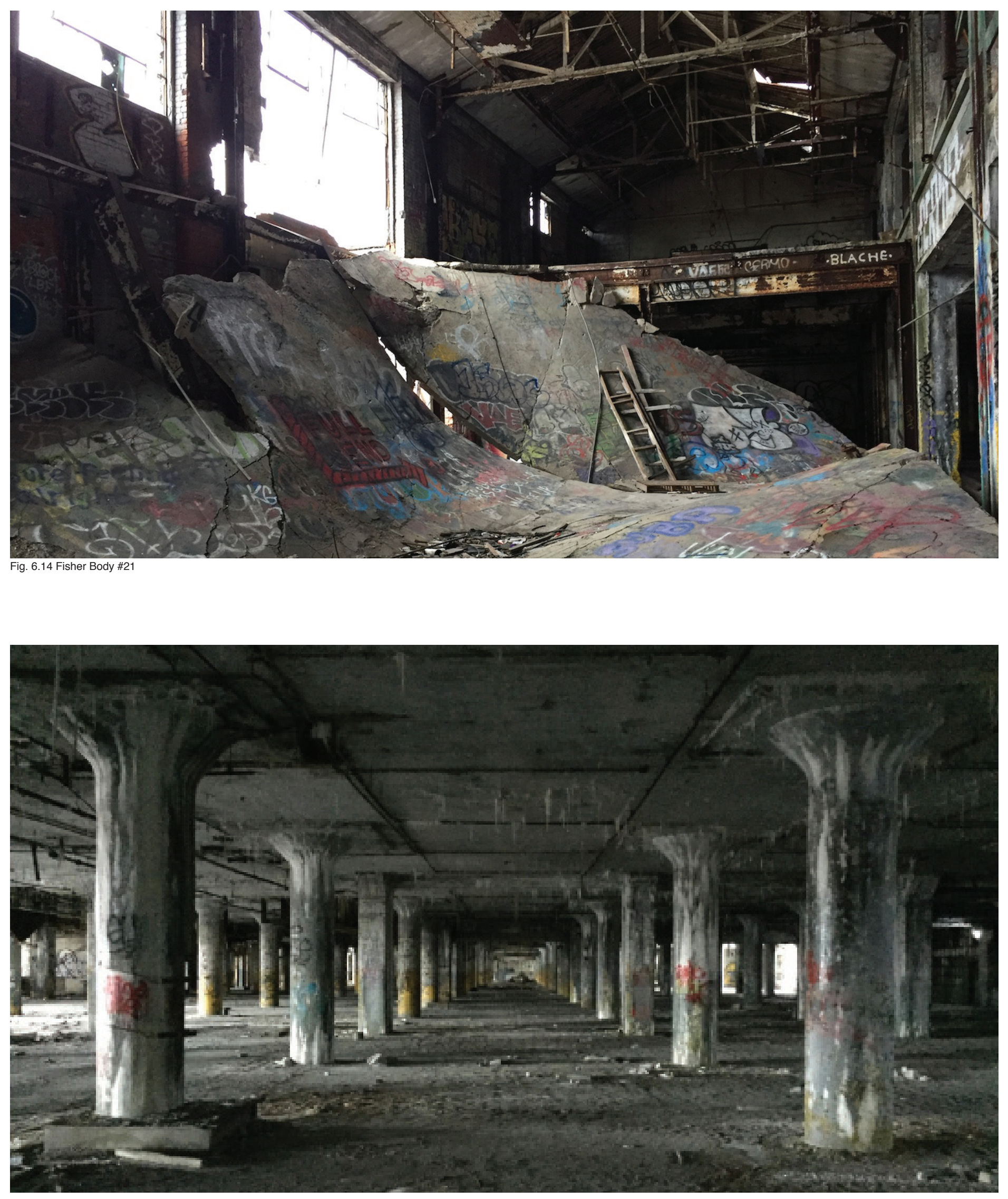

Fig. 6.15 Fisher Body \#21 


\section{Chapter 7 - Building Strategy and Design}

\subsection{Project Delivery Phases}

The proposal for the adaptive re-use of Fisher Body \#21 will be implemented in phases

Phase 1 - Plan Community Engagement

-Community needs and interests will be identified through a series of neighborhood design charrettes and community trade and skill shows.

- Program determined through community engagement

Phase 2 - Secure Financing Through Not-For-Profit Funding Mechanism

Phase 2 - Environmental Protection

Site cleanup by Detroit residents who are trained in areas of:

- Soil remediation

- Asbestos removal

- Lead Removal

- Polychlorinated Biphenyls (PCB's) removal

Phase 3 - Construction - Energy Retrofit

- Insulation upgrade, replace windows where necessary, Update HVAC, etc.

Phase 4 - Interior alterations

Phase 5 - Building Occupation 


\subsection{Program}

The proposed design will include appropriate programming for the community being served by the building. This will have been determined through the community engagement phase of the project, as well as the site planning as determined earlier in this document. A such, the program includes; music rehearsal studios, educational classrooms, light industrial workshop spaces, art studios, low income live / work residences, a skateboard park, community gardens / farmers market, and a flexible recreational / event space.

As previously mentioned, a report prepared by the Alfred Taubman College of Architecture and Urban Planning titled 'History's Future in the North End', identifies that the "building has great potential for reuse due to the glass wall construction and its high level of visibility from Interstates 94 and 75 . Inside the building, most of the production line still remains on the top floor and could be preserved as an exhibit on assembly line production." (Fig. 7.1) (Elliot, Feingolds, et al. 2013).

The space will be designed using the 'slack space' theoretical approach to design, focusing on an allencompassing flexibility and a sense of ambiguity; the individual studios and work spaces within the building will be designed so that they can be moved and rearranged to suit the needs of the users as they change over time.

Furthermore, part of the design strategy contained herein will embrace the preservation of the fortuitous disorganization, appropriated canvas and inherent ruinous aesthetic of the of the chosen site (Fig. 7.2). Such an approach can achieve goals of creating affordability of space and diversity of use, while also creating a place of memory, creativity, pleasure, and sensorial dynamism which can foster imaginative cultural production.

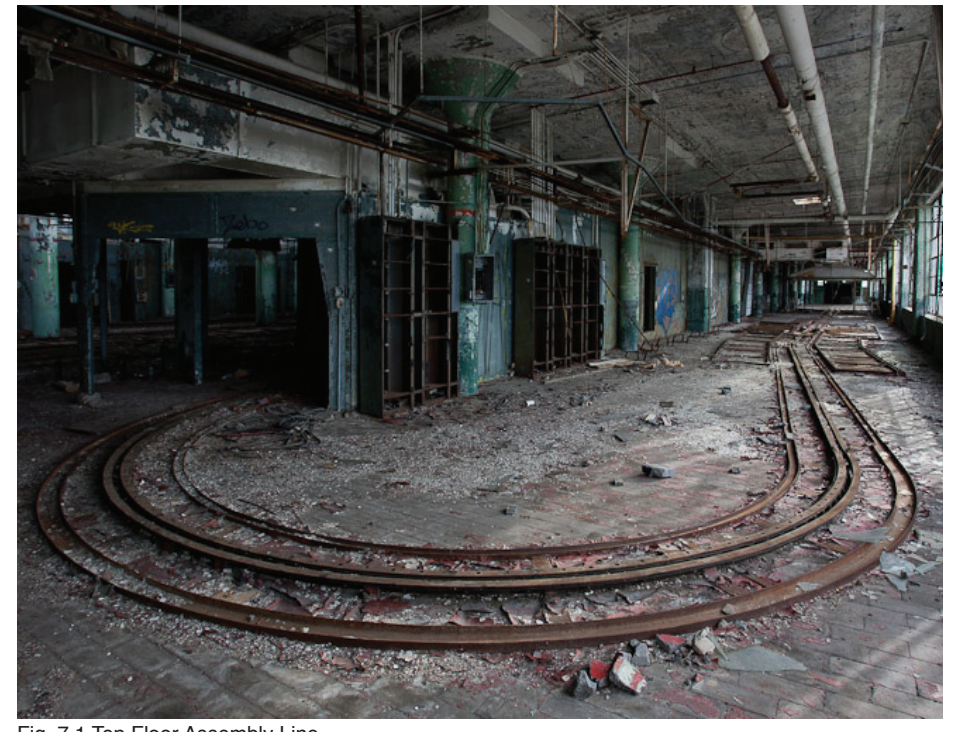

Fig. 7.1 Top Floor Assembly Line

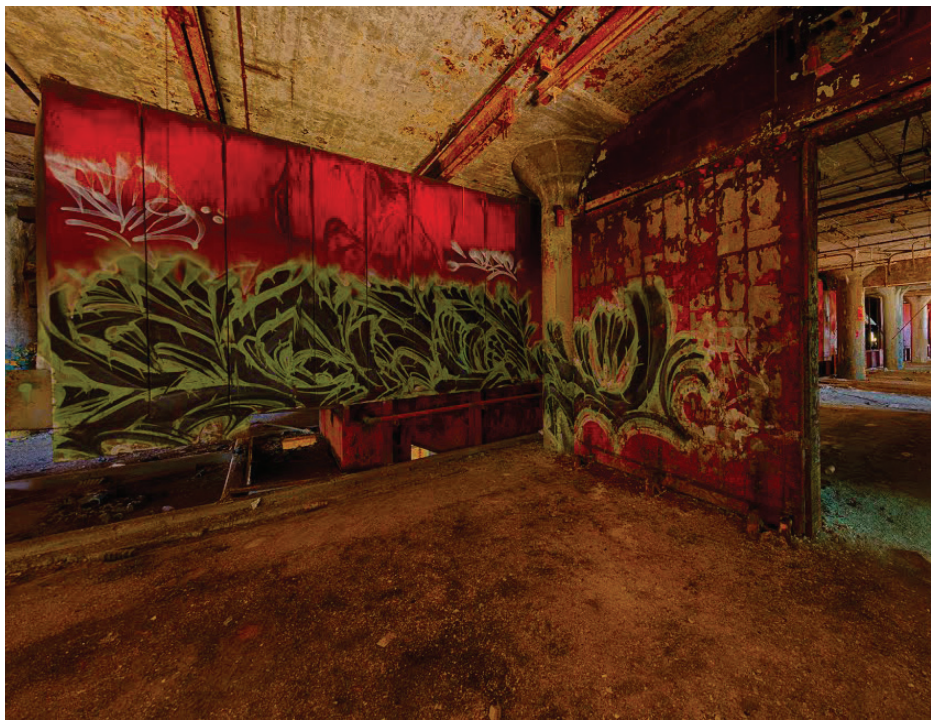

Fig. 7.2 Ruinous Aesthetic 


\subsection{Retrofit Strategy}

There is an inherent challenge in re-purposing buildings to ensure that energy efficiency requirements are met and thermal comfort for users is achieved. While Fisher Body \#21 has demonstrated its durability in the long-term performance of the concrete of which it was constructed, this characteristic represents challenges when designing for occupant comfort due to its high thermal conductivity and lack of insulation.

Due to heritage preservation concerns (Fisher Body \#21 is located within Detroit's 'Piquette Avenue Historic District' which was listed on the National Register of Historic Places in 2004), the retrofit strategy approach aims to preserve the historic facades facing Piquette Avenue, St Antoine St., and Hastings Avenue.

The following proposed actions will be taken with regards to the retrofit strategy of Fisher Body \#21:

- The damaged industrial sash windows will be repaired where possible, and replaced where needed. The replacement glazing will be high performance argon filled double glazed panes.

- In order to preserve the historic facades, insulation will be added to the interior of the exterior walls. The specified insulation should be that which minimizes air leakage. An airtight insulation layer will reduce the movement of air from warmer interior zones across the insulation, and eliminate the space between the insulation and the masonry where condensation normally occurs.

- Due to the size of building's footprint, the roof will be retrofitted to accommodate a green roof / community garden. This will reduce the building's heat island effect while providing a large space for growing fruits and vegetables, among other plant life.

- Portions of the floor that have collapsed or have structurally compromised will be repaired using comparable materials and technique.

- The waffle columns on the interior will remain intact where possible, and the graffiti that has been added to them will remain where appropriate

- The exterior pilasters will remain. 


\subsection{Architectural Design Strategy}

The design strategy for Fisher Body \#21 involves a number of large interventions. The Piquette Avenue facade will remain relatively intact to preserve its presence within the Piquette Avenue historic district. The main entrance to the building will be located to the rear of the building, off of Harper Avenue.

Currently, the rear of property contains a large patch of asphalt which encompasses approximately the same area as the building's footprint which had previously been used as a parking lot. In the new design, some parking will be incorporated into this area, but priority will be paid to a new park / green space, bicycle parking, and an outdoor recreation area.

At some point in the buildings history, a 2 storey wooden structure was added to the rear of the building, which has since been damaged by arson fire (Fig. 7.3). This will be removed and replaced by a new glazed window wall (Fig 7.11, 7.21).

A $2 \times 6$ bay volume will be cut from all floors a the buildings entrance to provide a dynamic, bright, voluminous atrium space at the building entrance. The exterior wall at this portion will consist of a structural glazed curtain wall which extends the entire height of the volume (Fig 7.21.).

The elevator core will be located at the center of the building where there is an existing core. Additional exit stairs will be provided to the west and east of the central core, as well as on the south east and south west of the building.

On the north side of the building, a $3 \times 4$ bay volume will be cut from the second and third floor to accommodate a basketball court on the first floor. Additionally, the same volume will be removed from the 6th floor to accommodate a double height theater on the 5th floor.

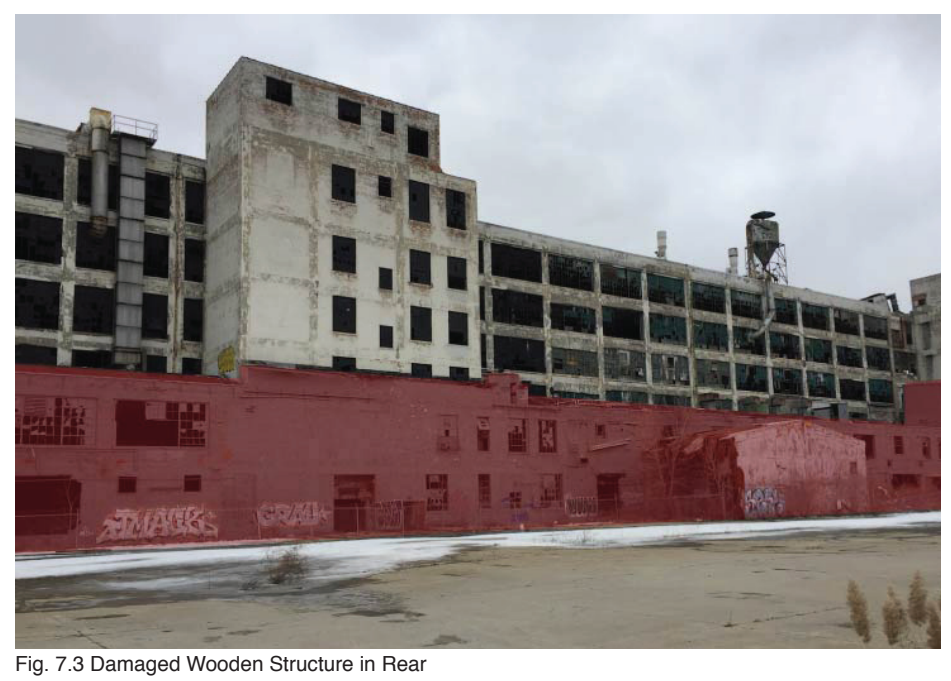




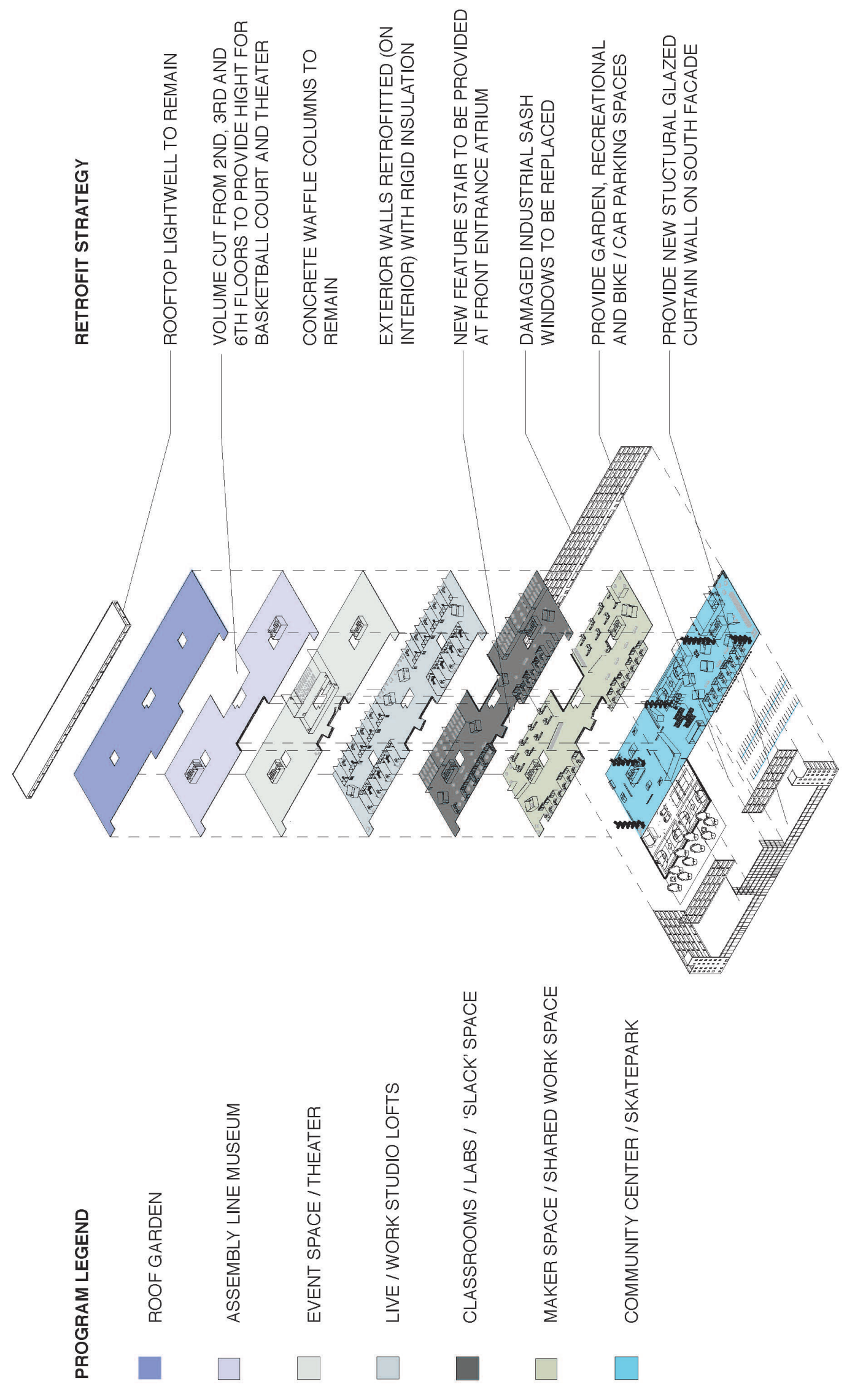




\subsection{Design Proposal}

The following images present the proposed design exploration for the adaptive reuse of the Fisher Body \#21 Building. The list of drawings include:

Site Plan

Site Axonometric

Ground Floor Plan

Second Floor Plan

Third Floor Plan

Fourth Floor Plan

Fifth Floor Plan

North Elevation

South Elevation

East Elevation

West Elevation

East / West Section

North / South Section

Rendered Elevation

Sectional Perspective

Approach Perspective

Approach Perspective 2

Interior Perspective 1

Interior Perspective 2

Interior Perspective 3

Interior Perspective 4

Interior Perspective 5 


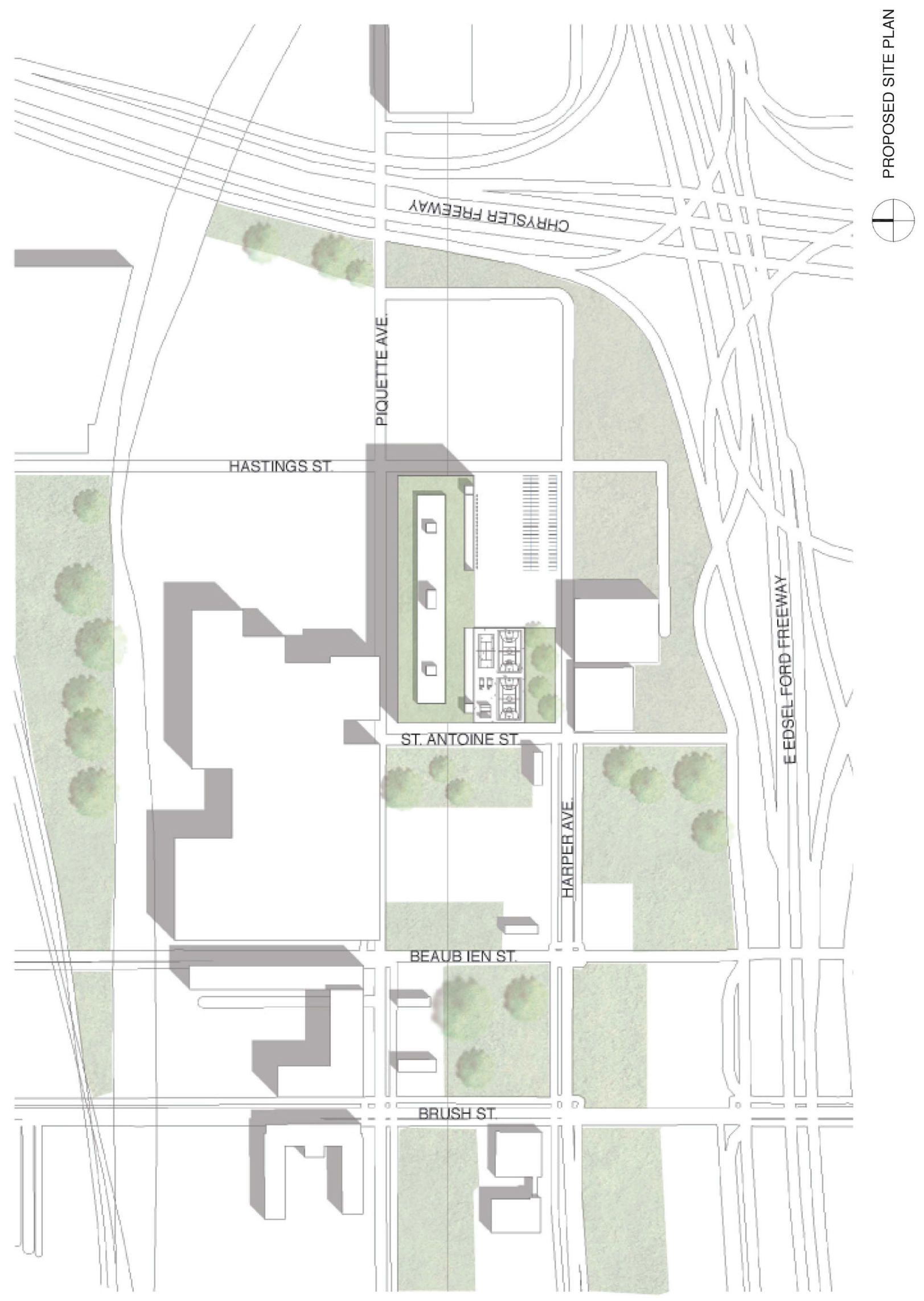




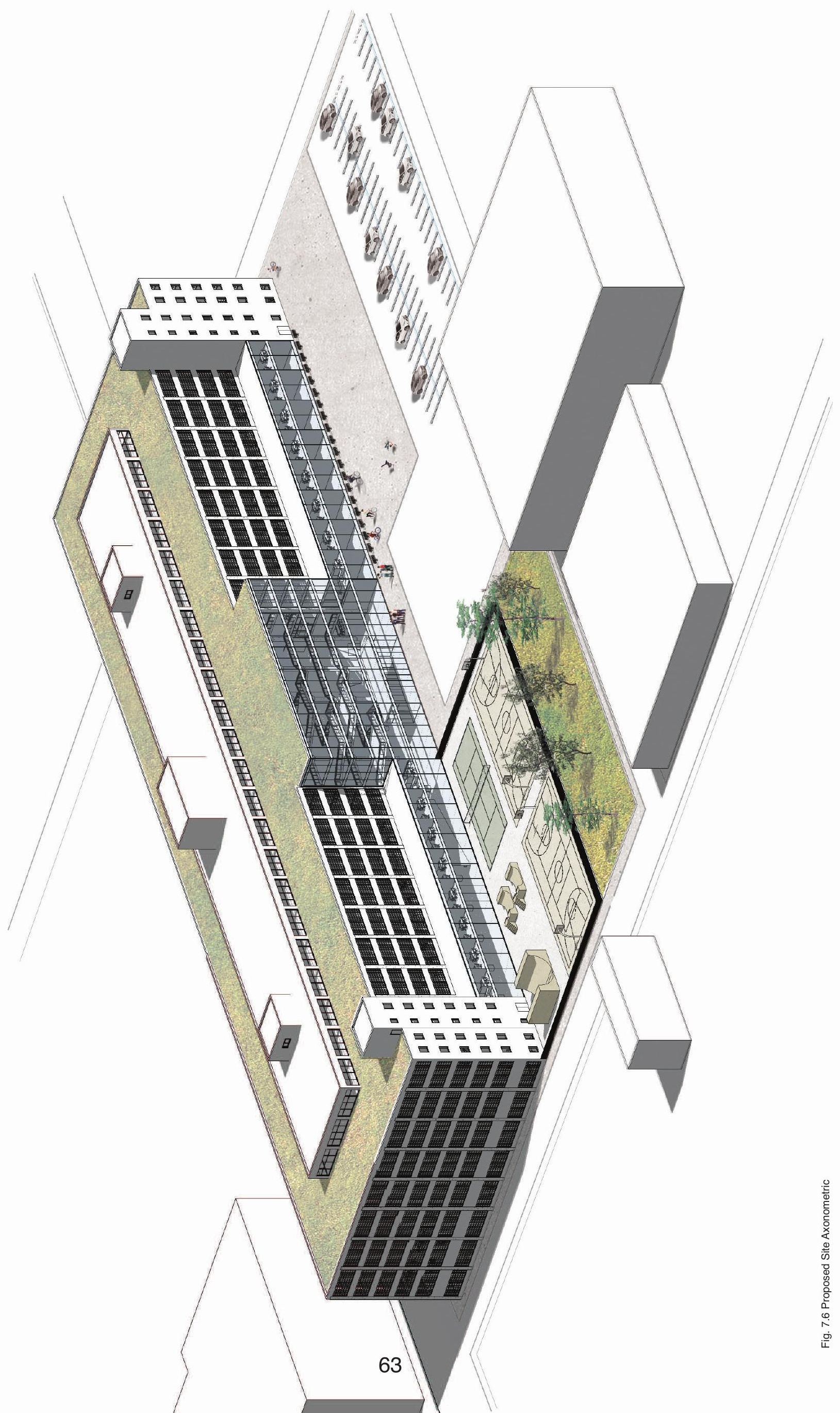




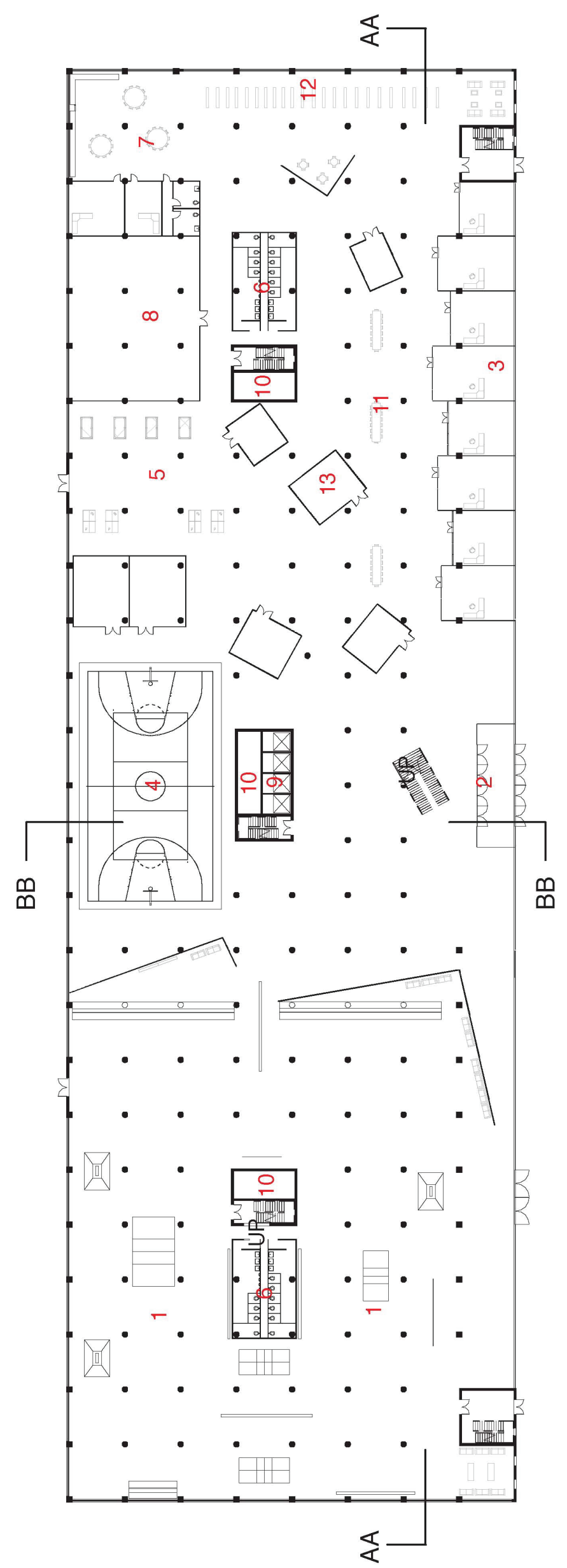

$\square$

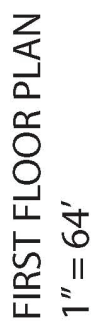

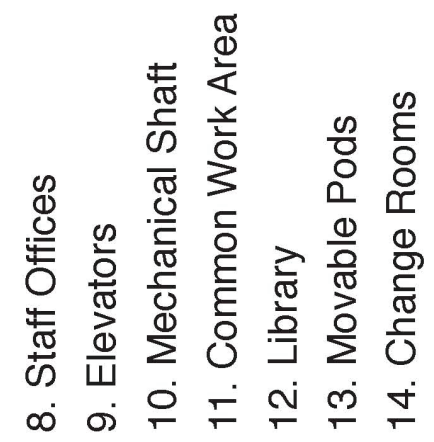

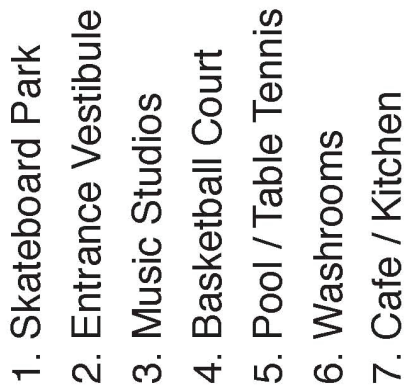



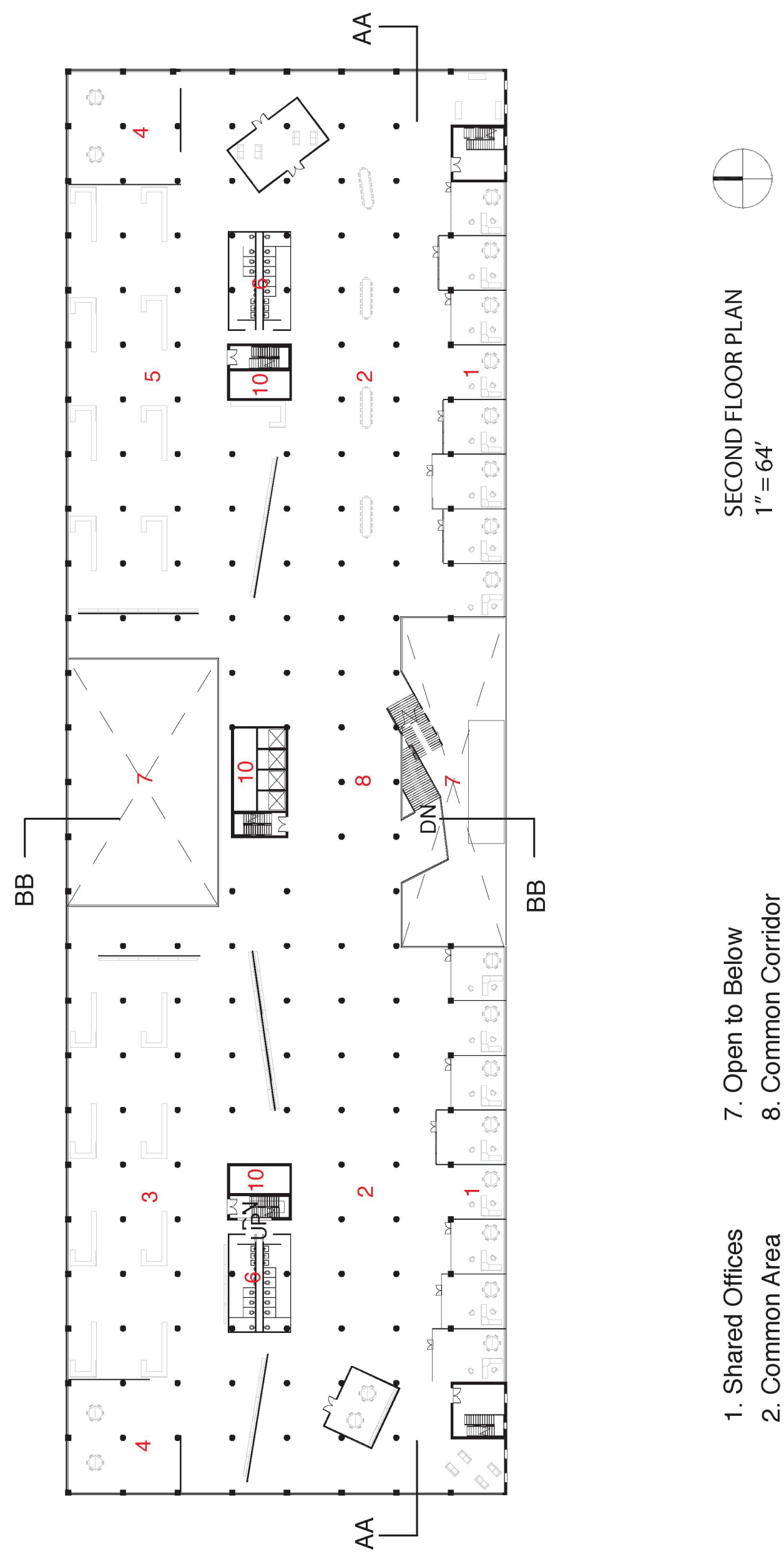

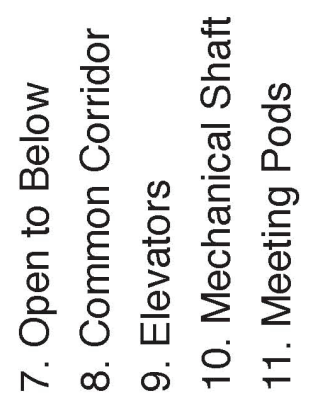

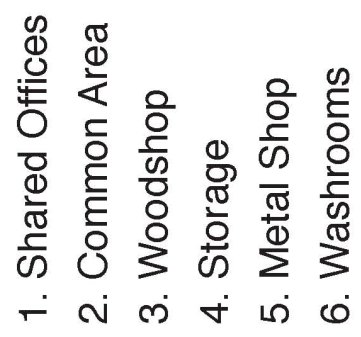




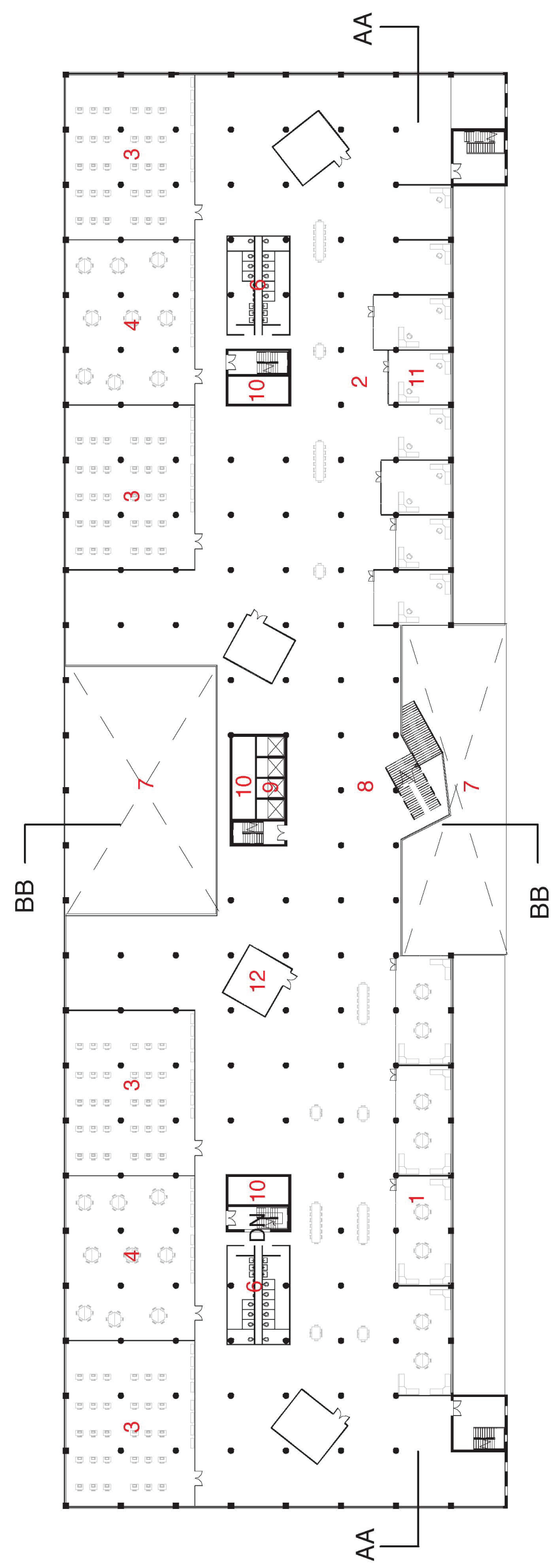

$\theta$

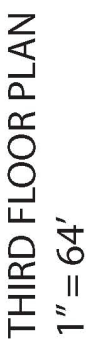

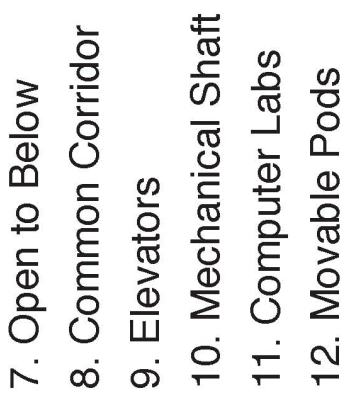

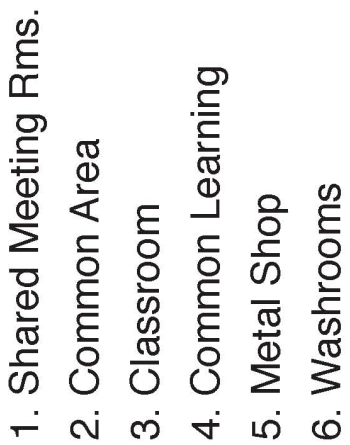




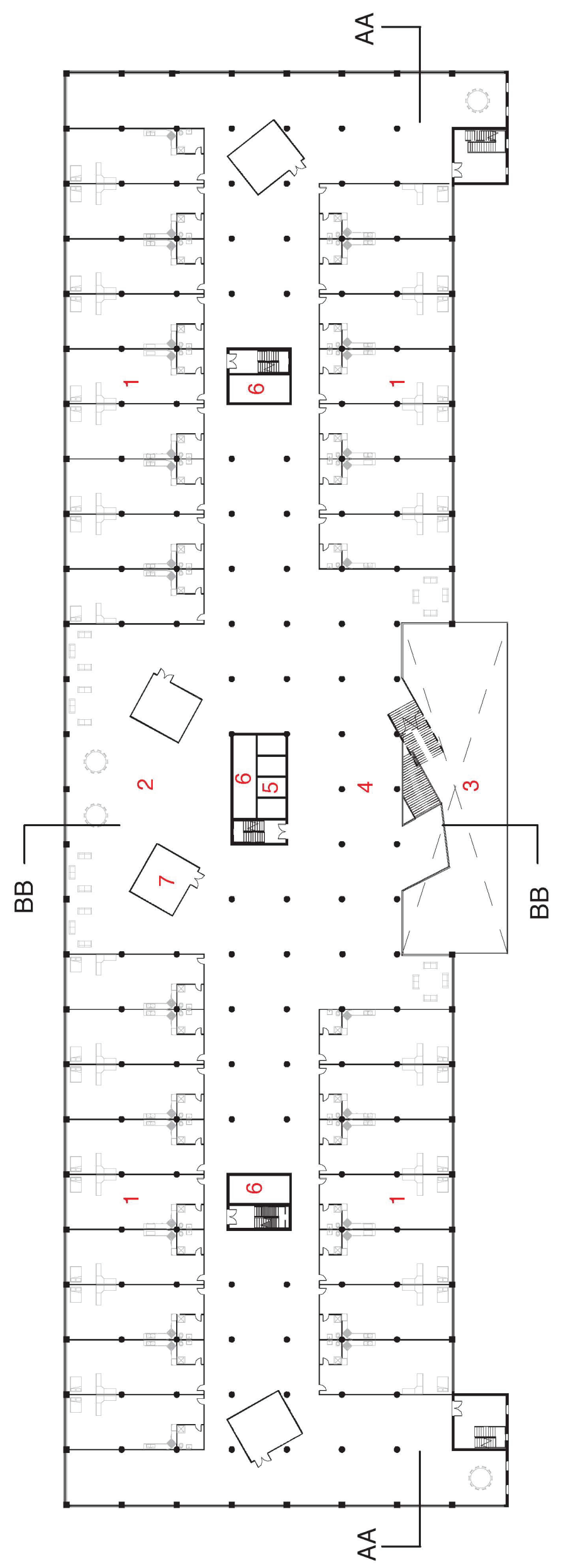

$\theta$

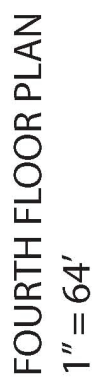

$\frac{0}{0}$
0
0
$\frac{0}{0}$
$\frac{0}{00}$
$\frac{0}{2}$
$N$

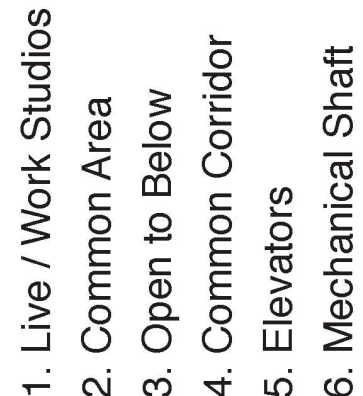



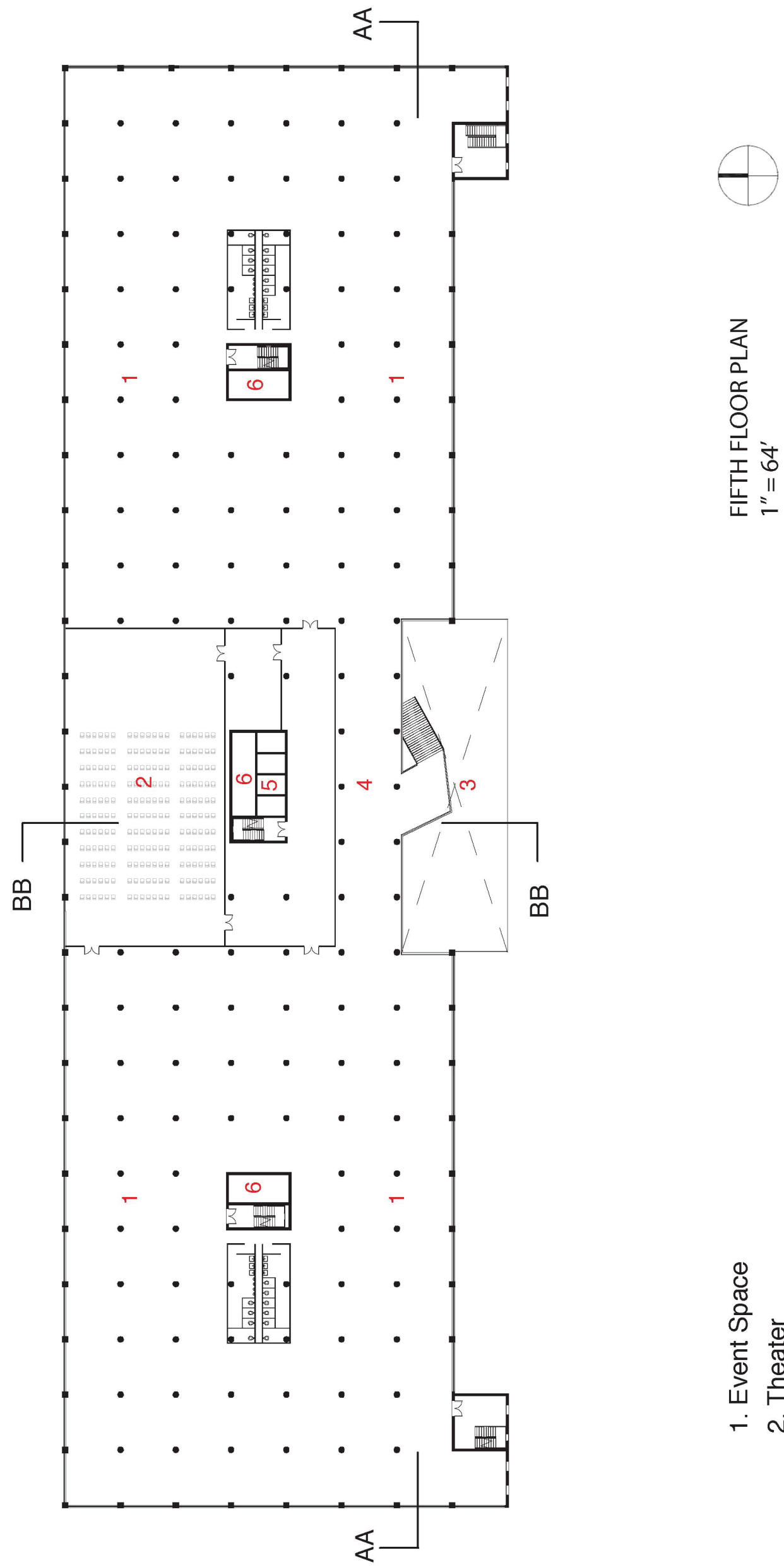

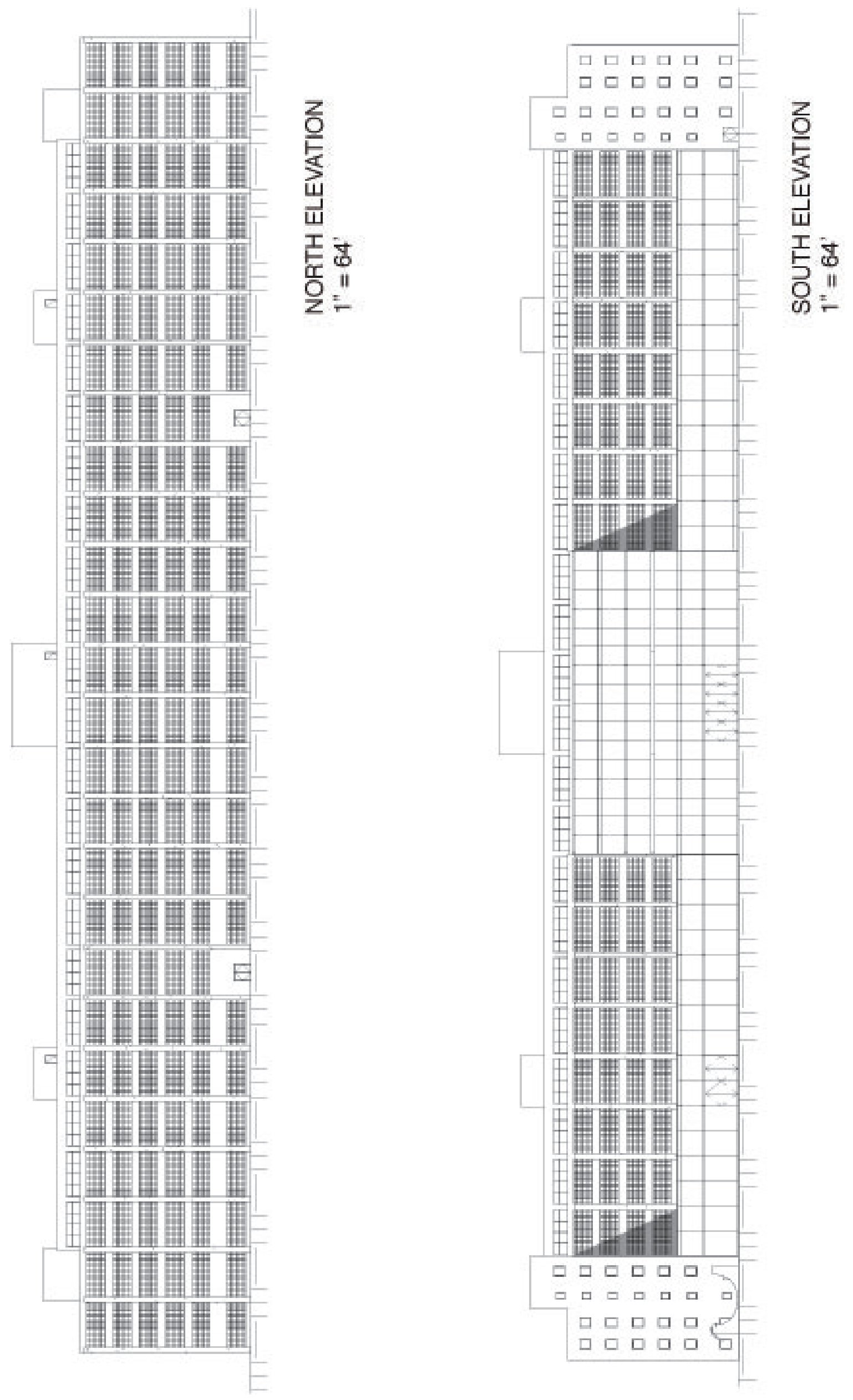

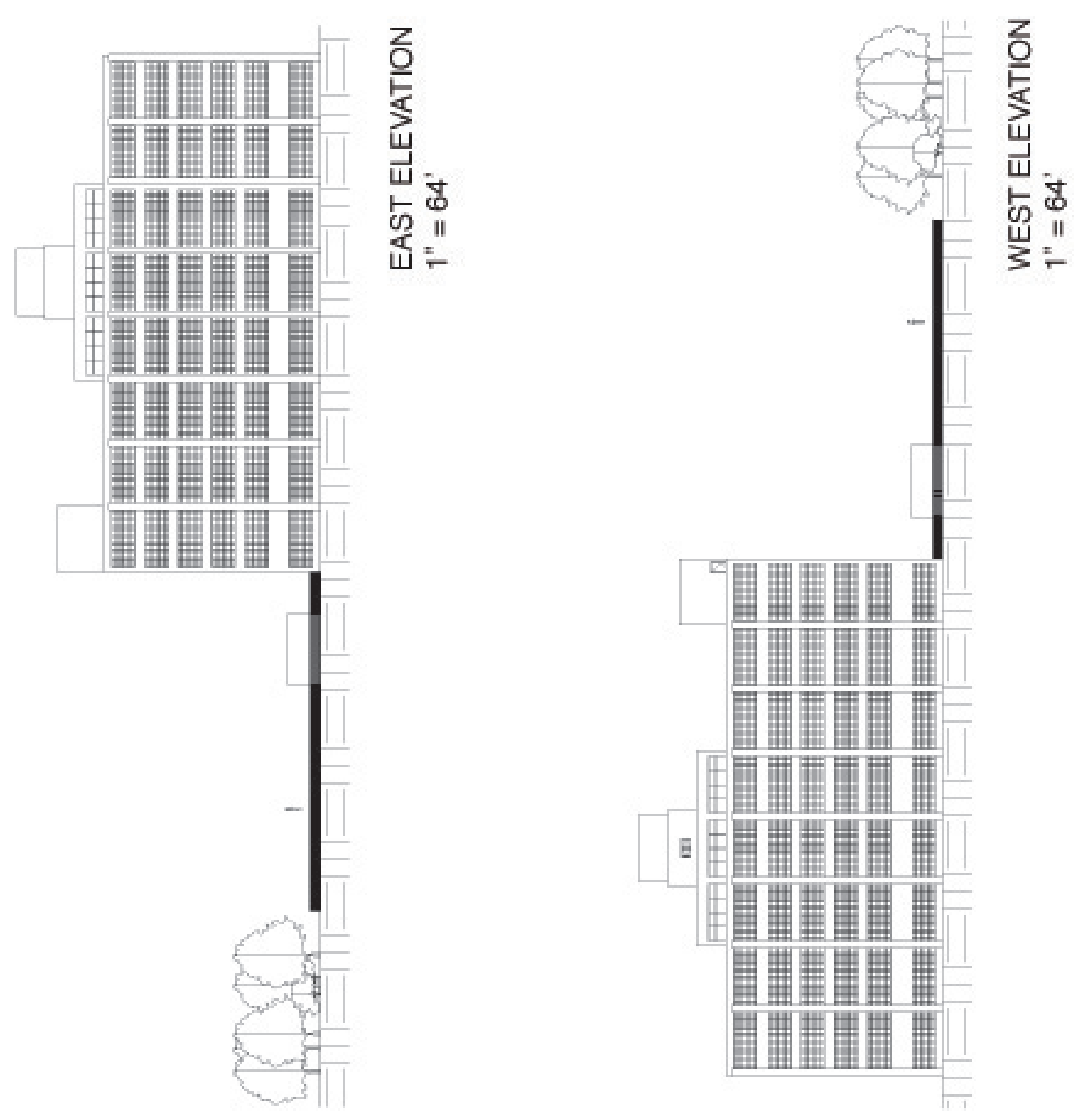

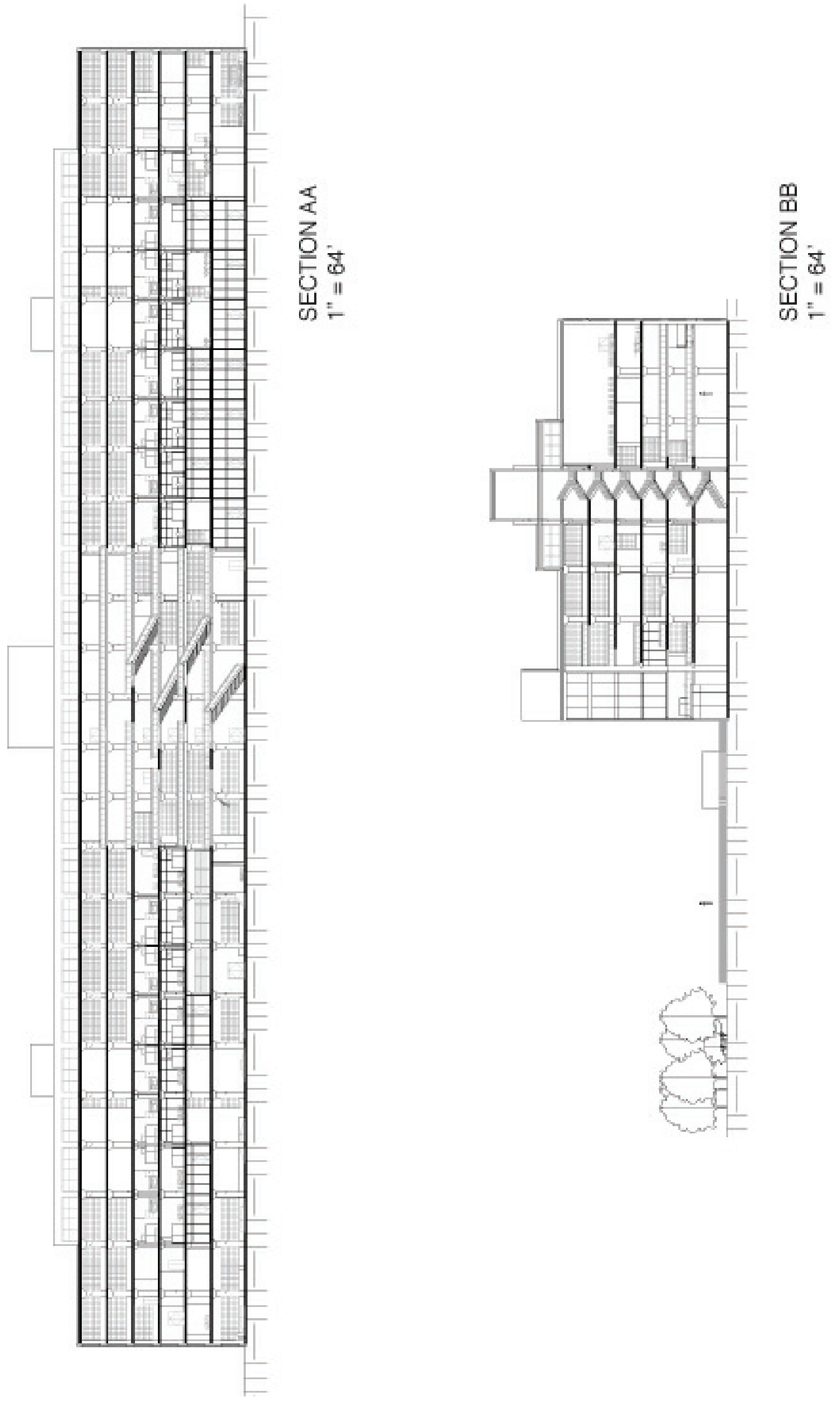


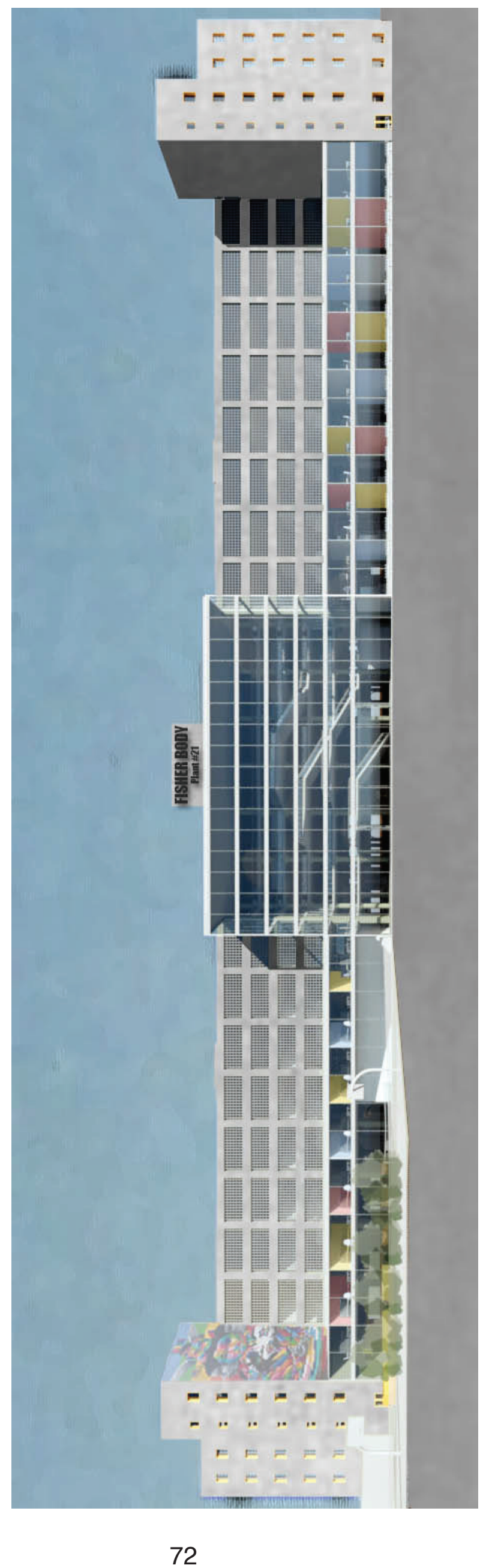

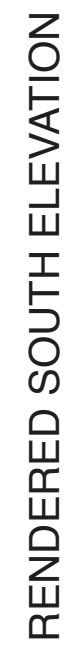




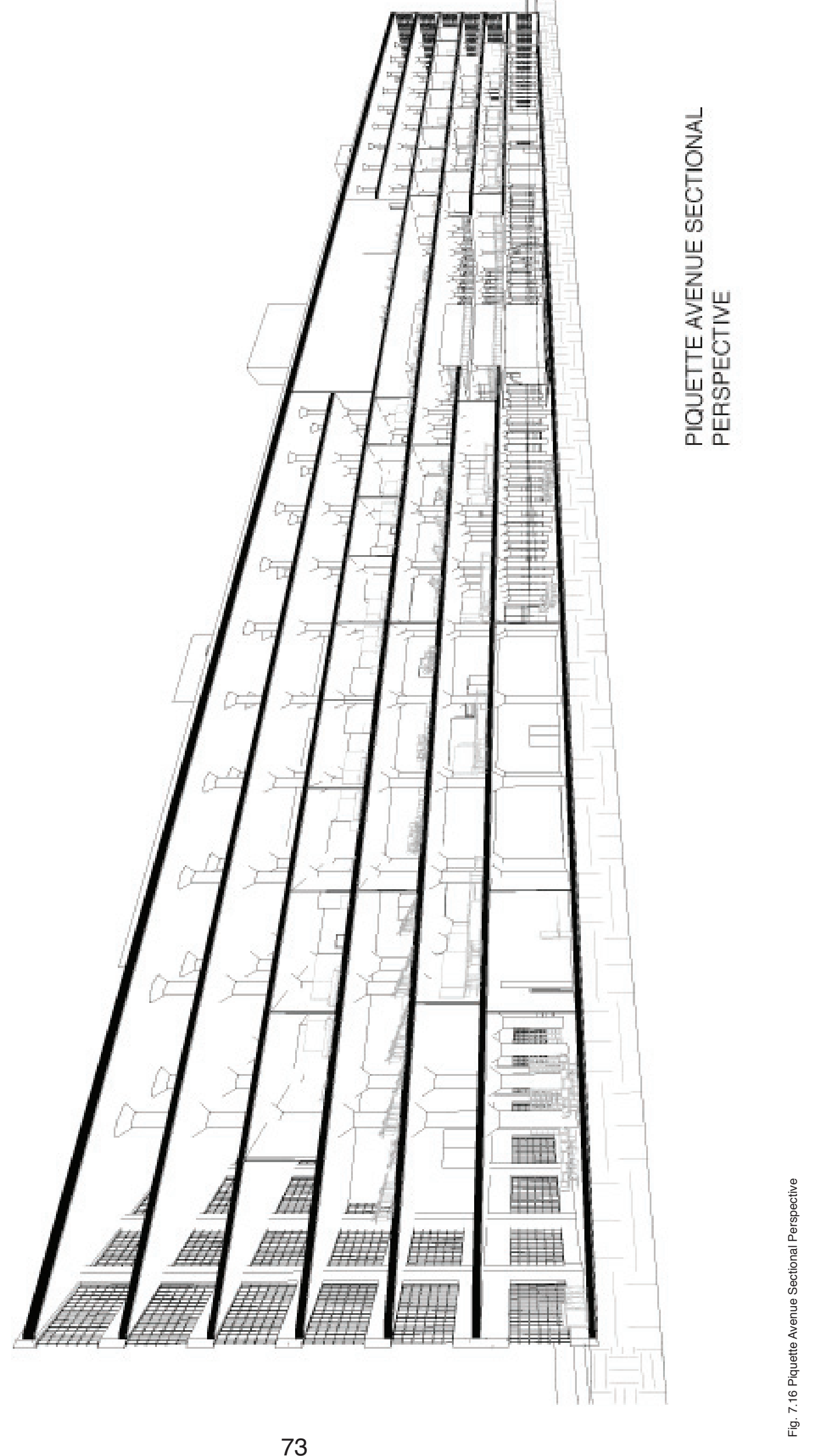




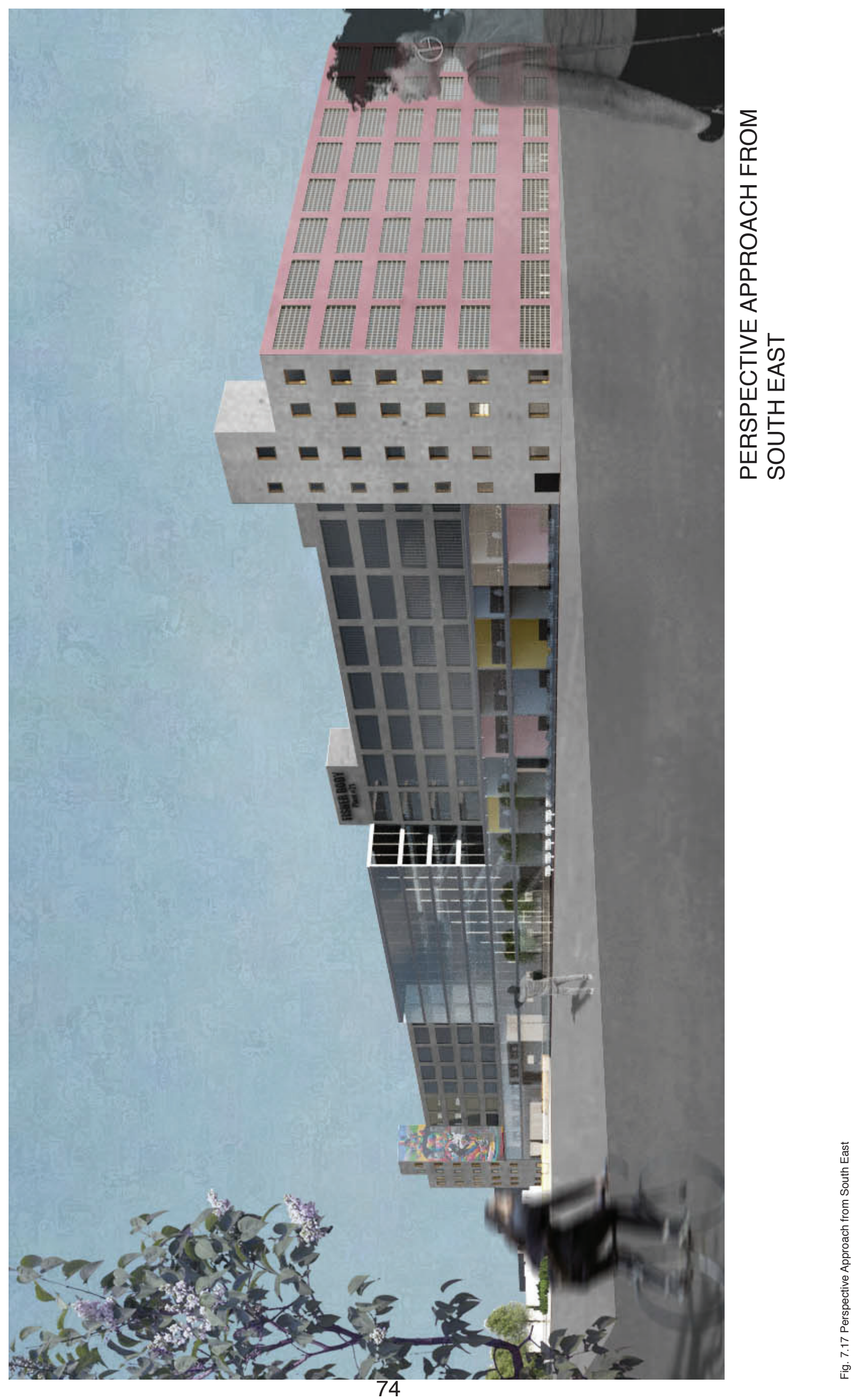




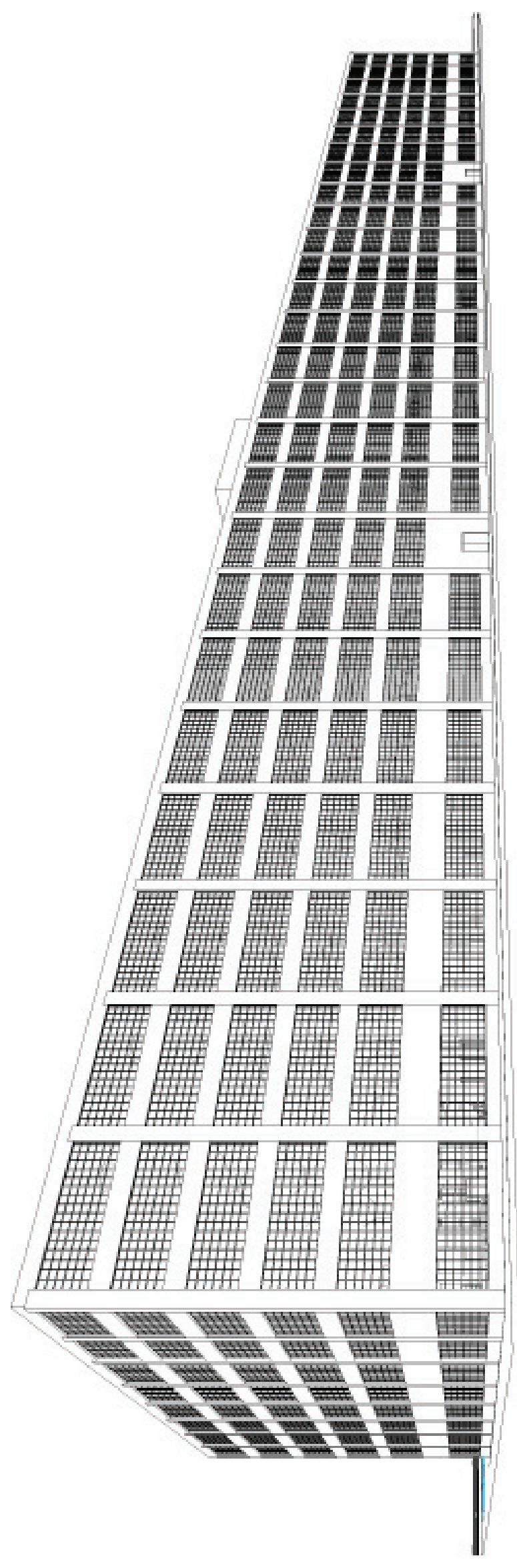

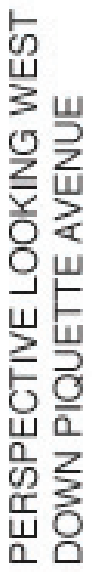




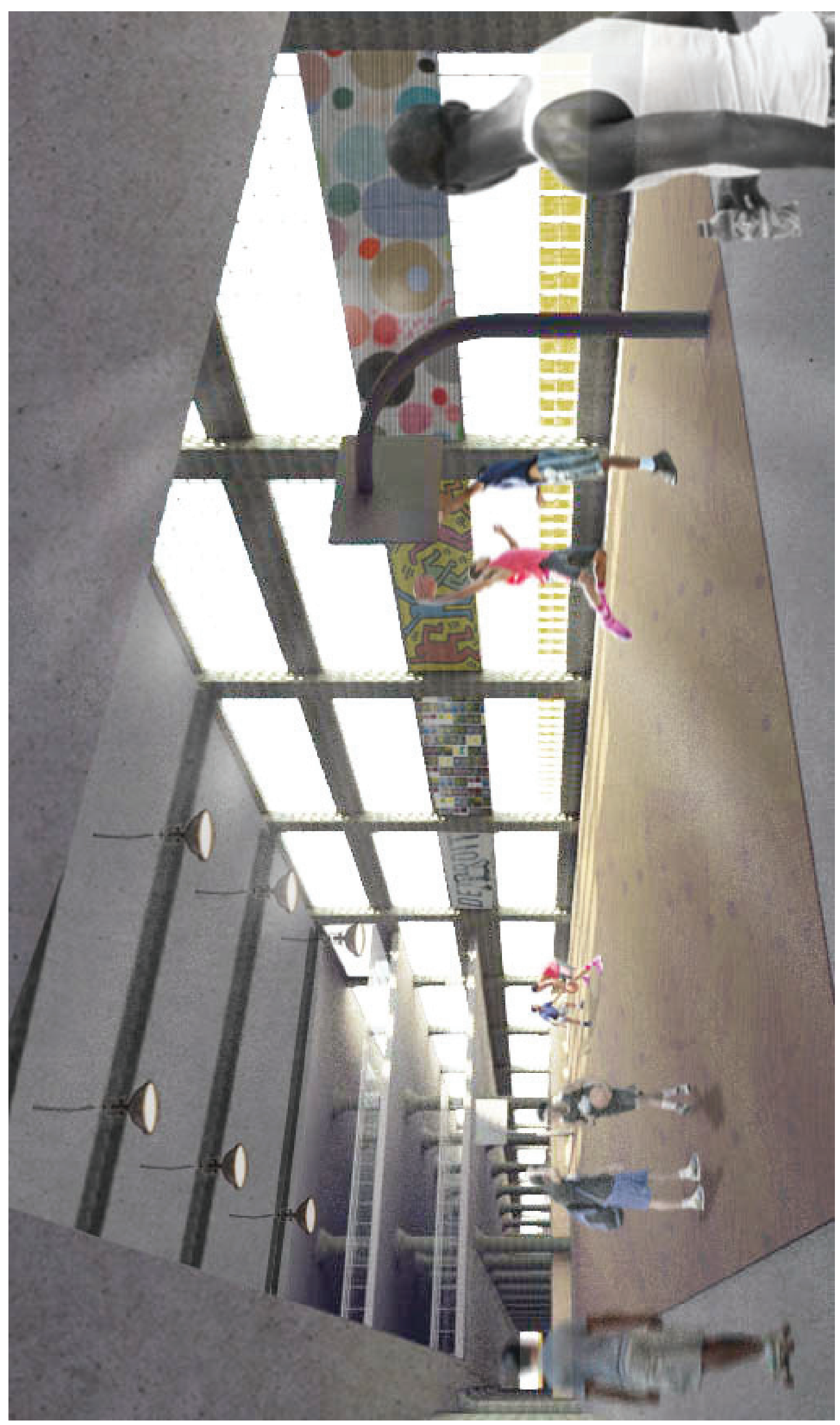

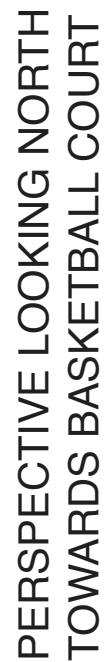




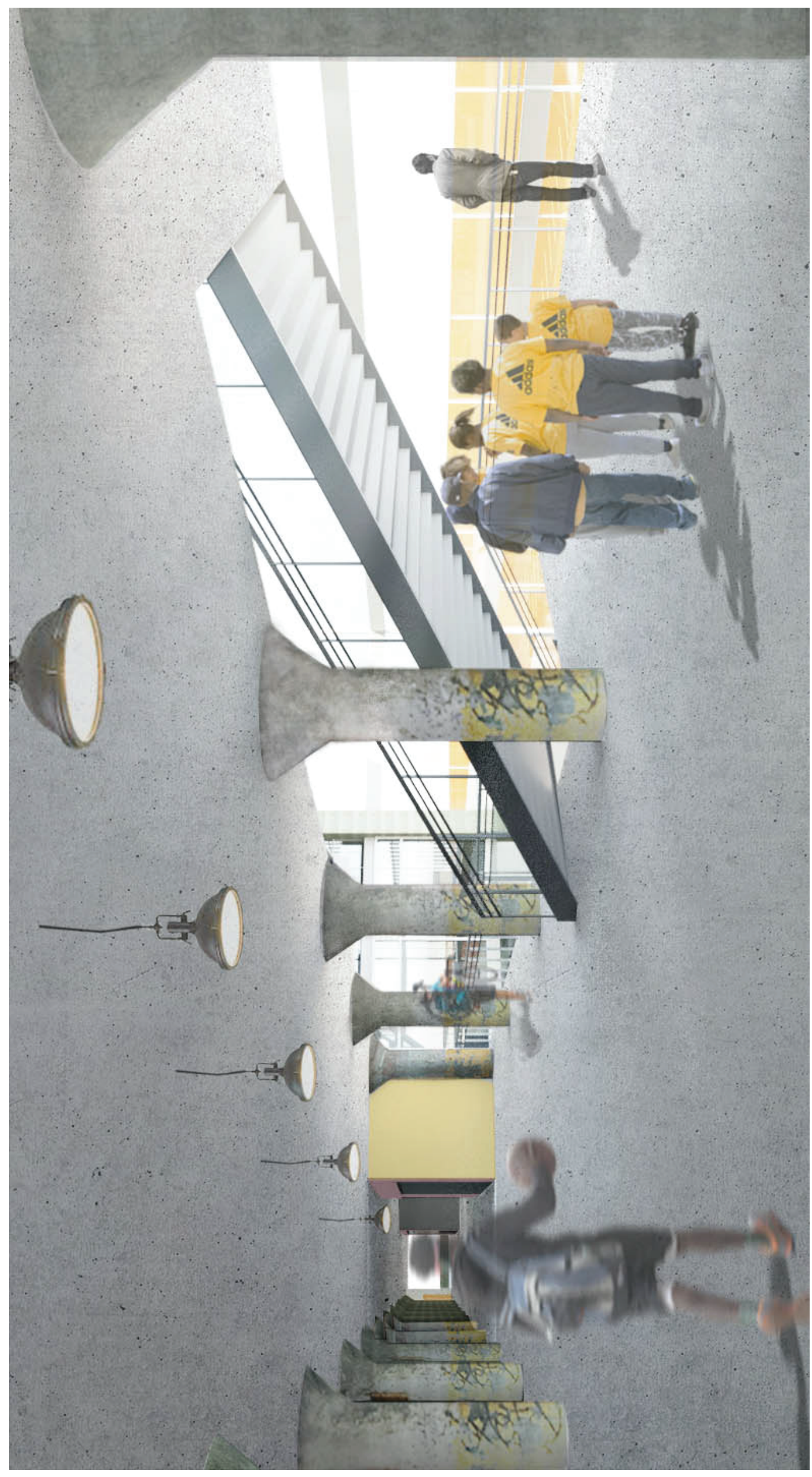

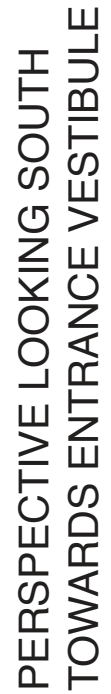




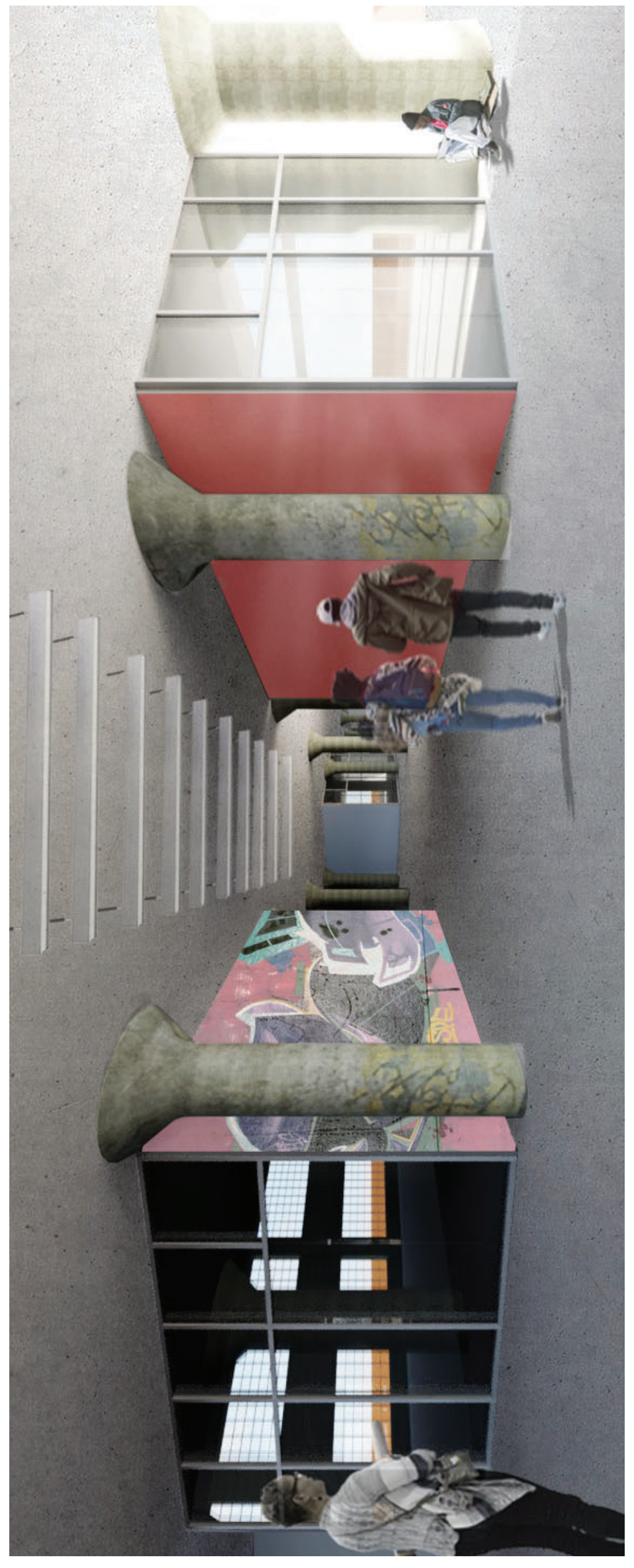

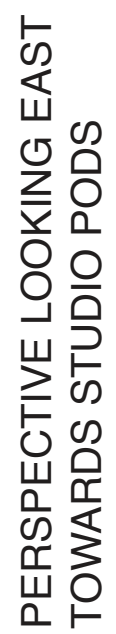




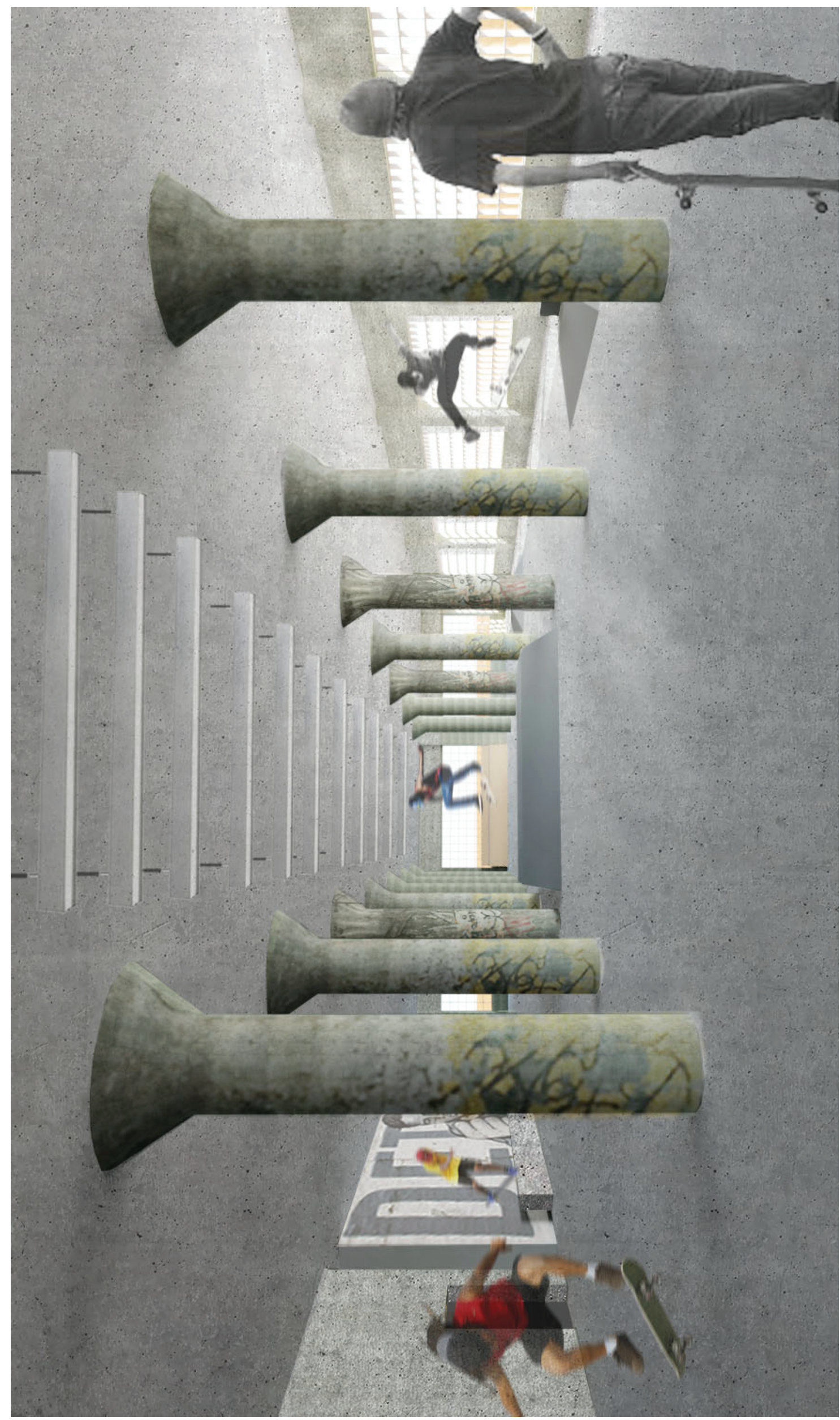

恕

$\frac{\text { V }}{Z}$

Oิ

Oำ

世

㟧

E

山

용

등

ш

ㄴ 


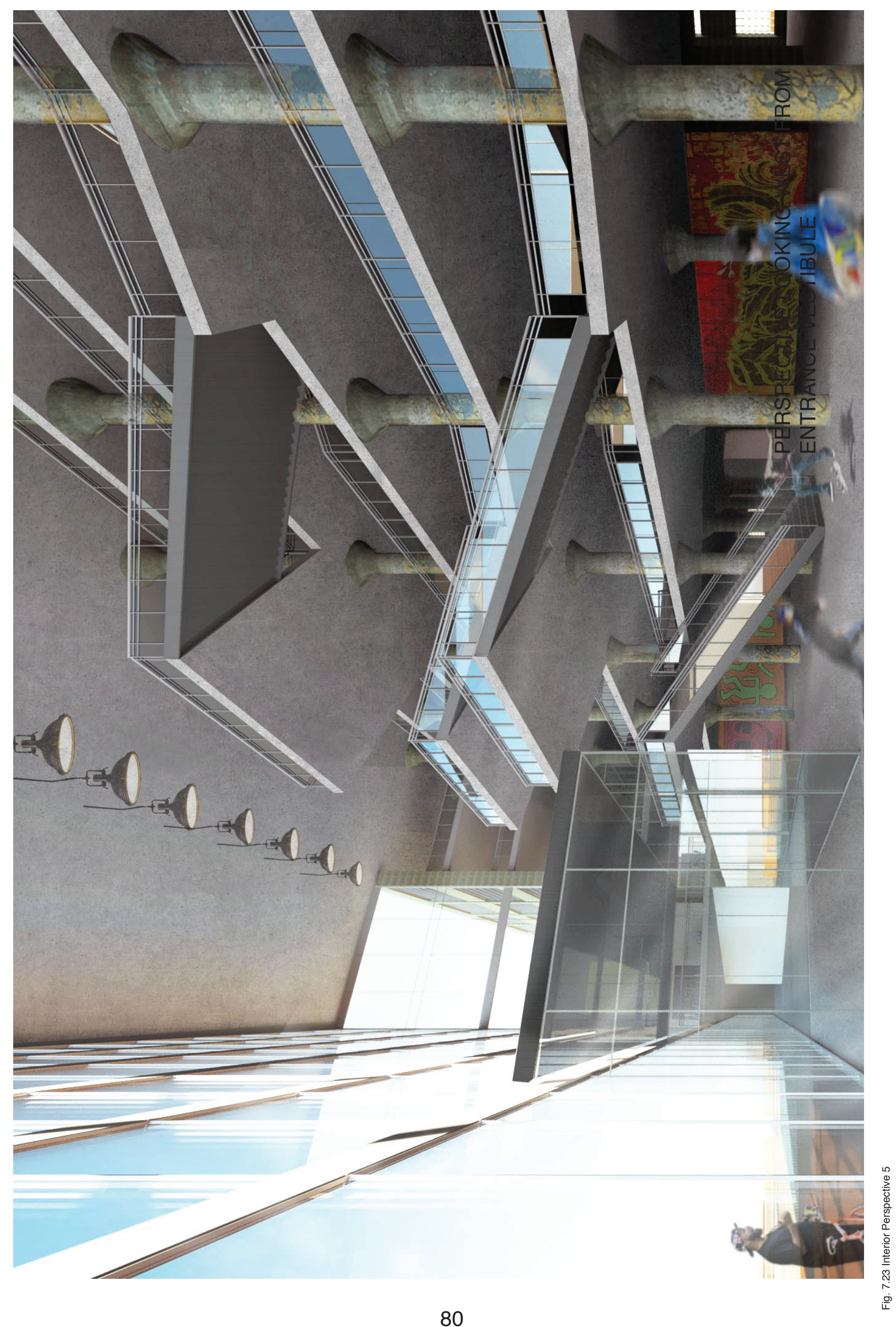




\section{Chapter 8 - Conclusion}

Abandoned, unoccupied, and under-used industrial architecture and informal public space in the city of Detroit provides a scale and ubiquity, which is ideally positioned for re-use or re-appropriation as buildings and spaces where imaginative, alternative, and grass roots economic practices can be fostered and stimulated in an affordable, safe, community led space. As the city of Detroit grows threatening displacement in the process, It is imperative to the healthy growth of city that developers and property value speculators show restraint in what should be seen as a delicate renewal process.

This thesis has explored an approach to adaptive reuse and re-appropriation in which such a space has been embraced and preserved as a place of cultural production, by prioritizing a use value over exchange value in the design approach of the Fisher Body \#21 building.

Further, the design strategy embraces the preservation of the appropriated canvas and inherent ruinous aesthetic of the of the Fisher Body \#21 building. Such an approach can achieve goals of creating affordability of space and diversity of use, while also creating a place of memory, creativity, and dynamism which can foster imaginative production in the areas of play, arts, and craft.

To design space as dynamic, whose meaning is not given but in a forever state of becoming; a space in which the users experience "is not represented or conceived, but lived", has been applied as a conceptual design theory. The design has provided spaces of leisure, play, and production: sports facilities, art studios, classrooms, makers spaces, shared office spaces, an event space and spaces for learning. Such spaces provide users with a facility to be in a dynamic state of becoming; to facilitate the production of movement, the production of craft, and the production of knowledge.

The displacement and lack of affordable space that occurs as a consequence of gentrification, ultimately undermines and threatens the rich cultural capital generated by local communities. A unique architec-

tural approach to indeterminacy and heterogeneous spatial composition as an adaptive reuse strategy can stimulate imaginative and alternative practices, and resist the forces of urban gentrification. 



\section{Appendices}

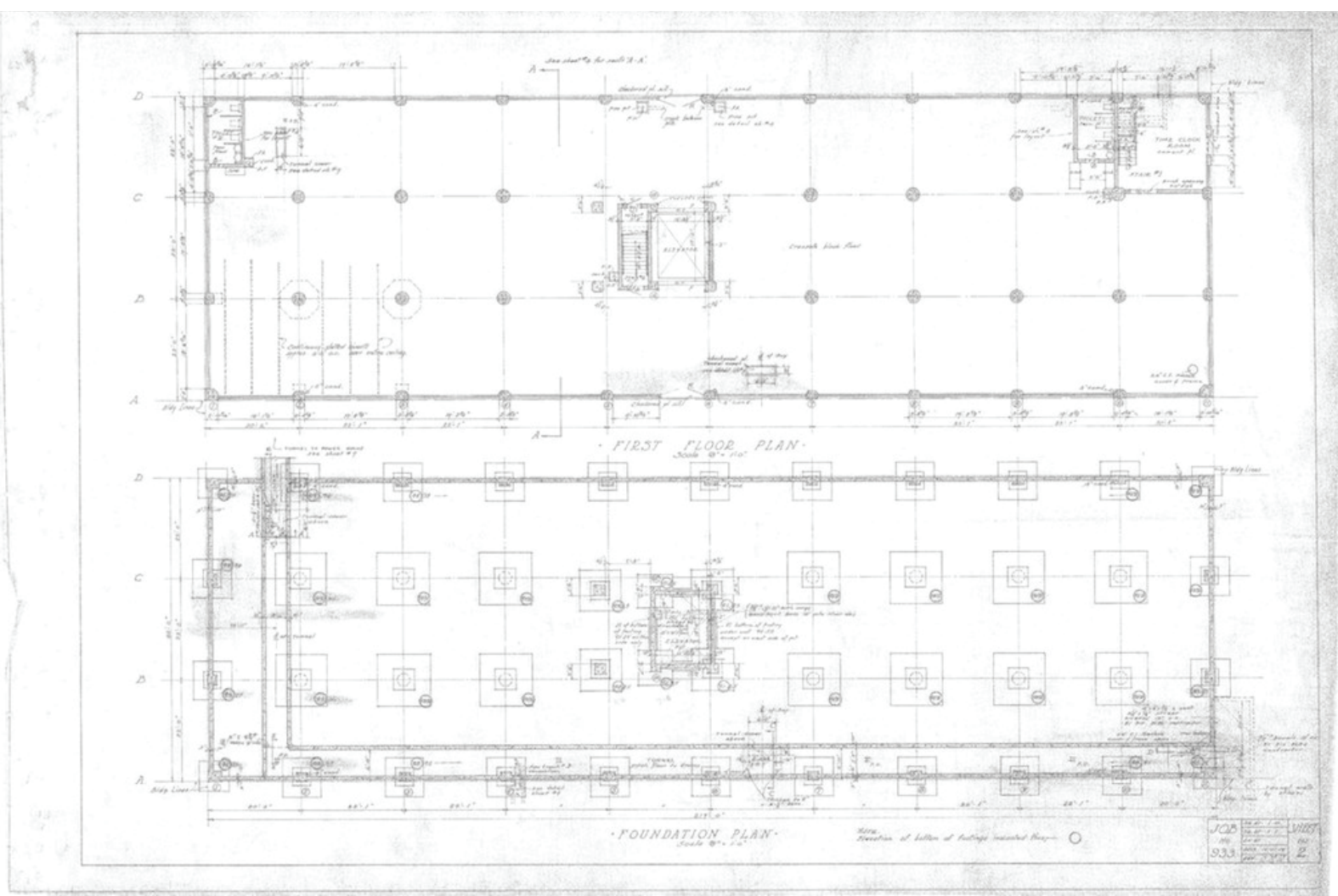

Fig. 8.1 Fisher Body Die Building Plans From Kahn and Associates

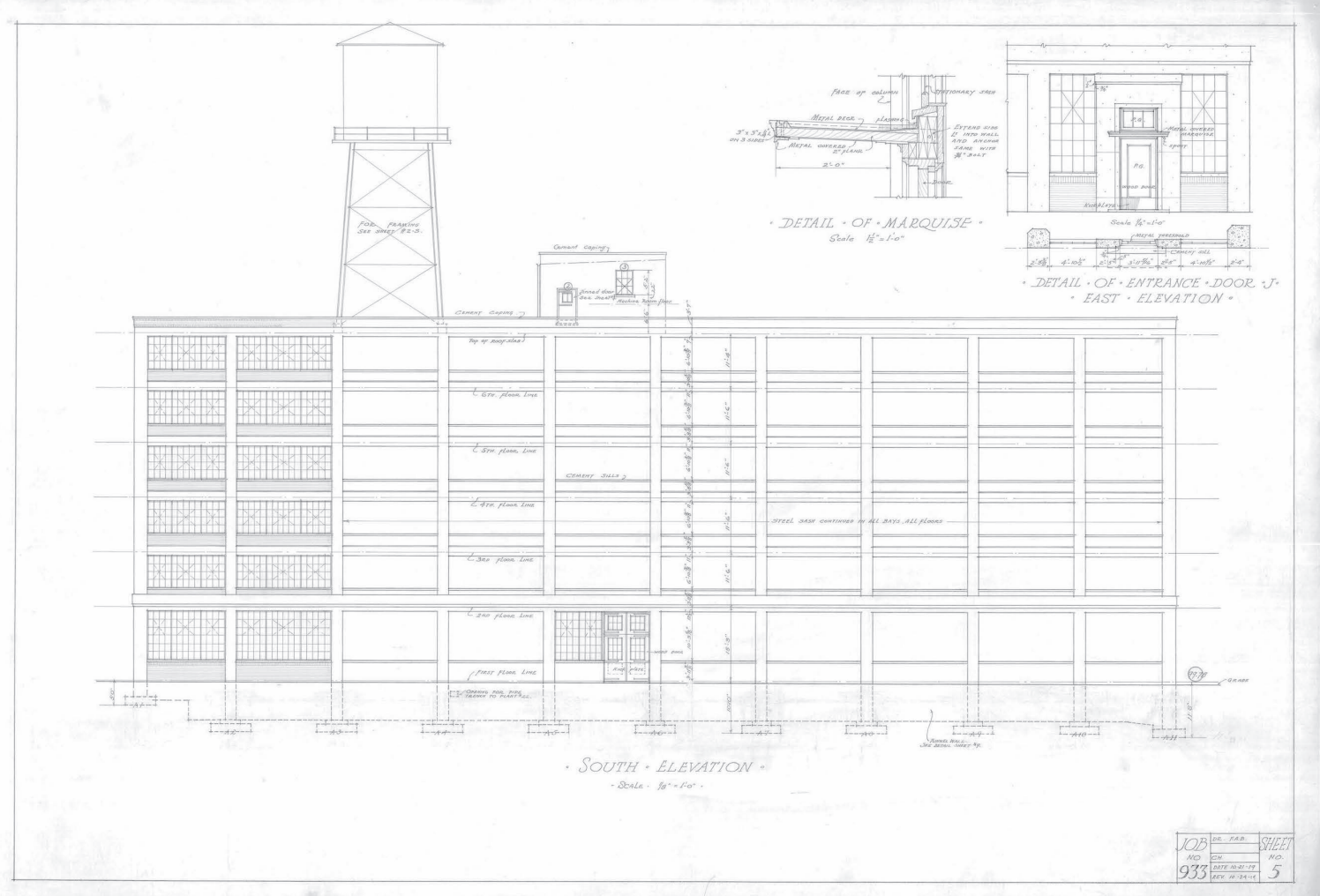

Fig. 8.2 Fisher Body Die Building Elevations From Kahn and Associates 


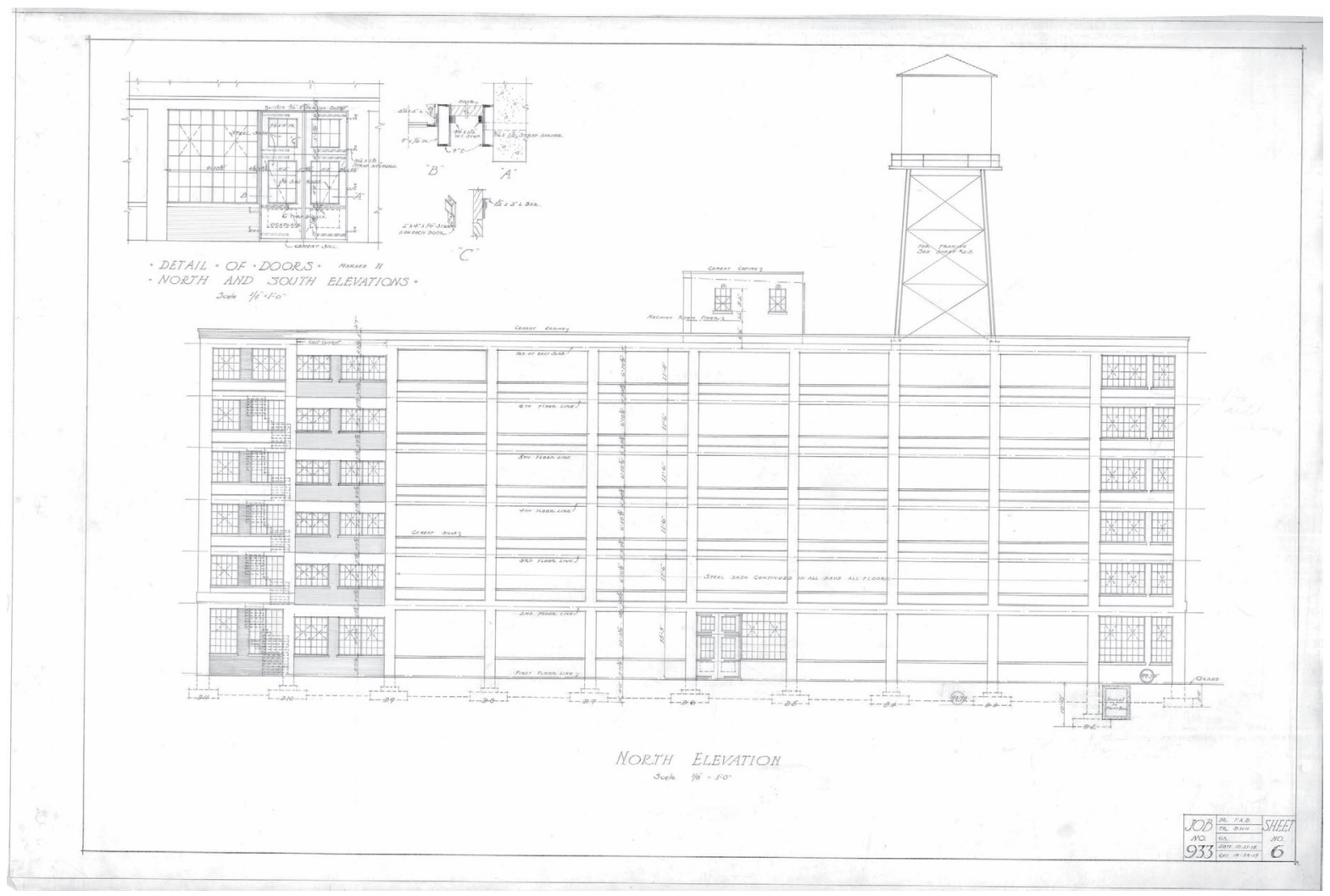

Fig. 8.3 Fisher Body Die Building Elevations From Kahn and Associates

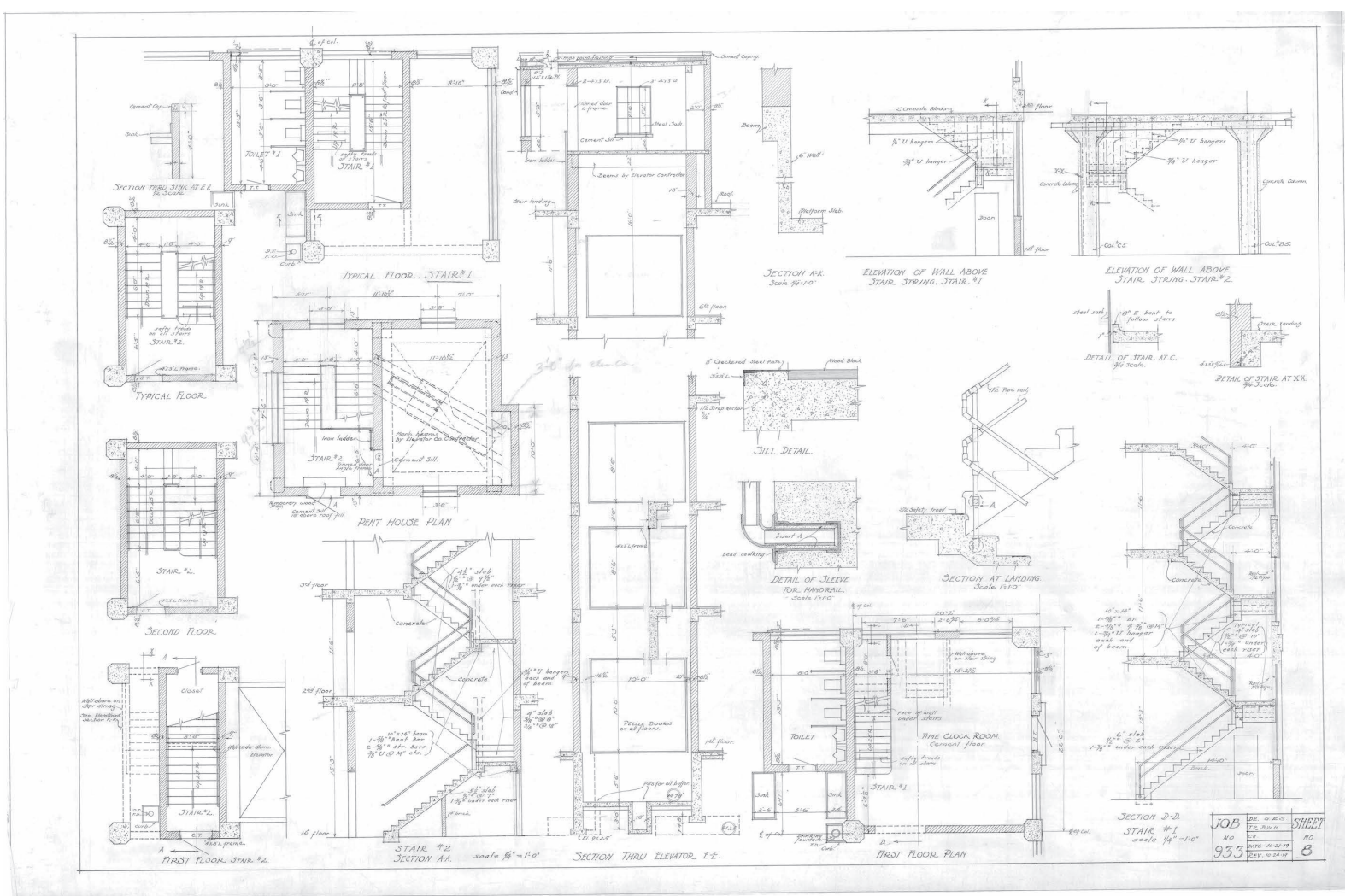

Fig. 8.4 Fisher Body Die Building Details From Kahn and Associates 

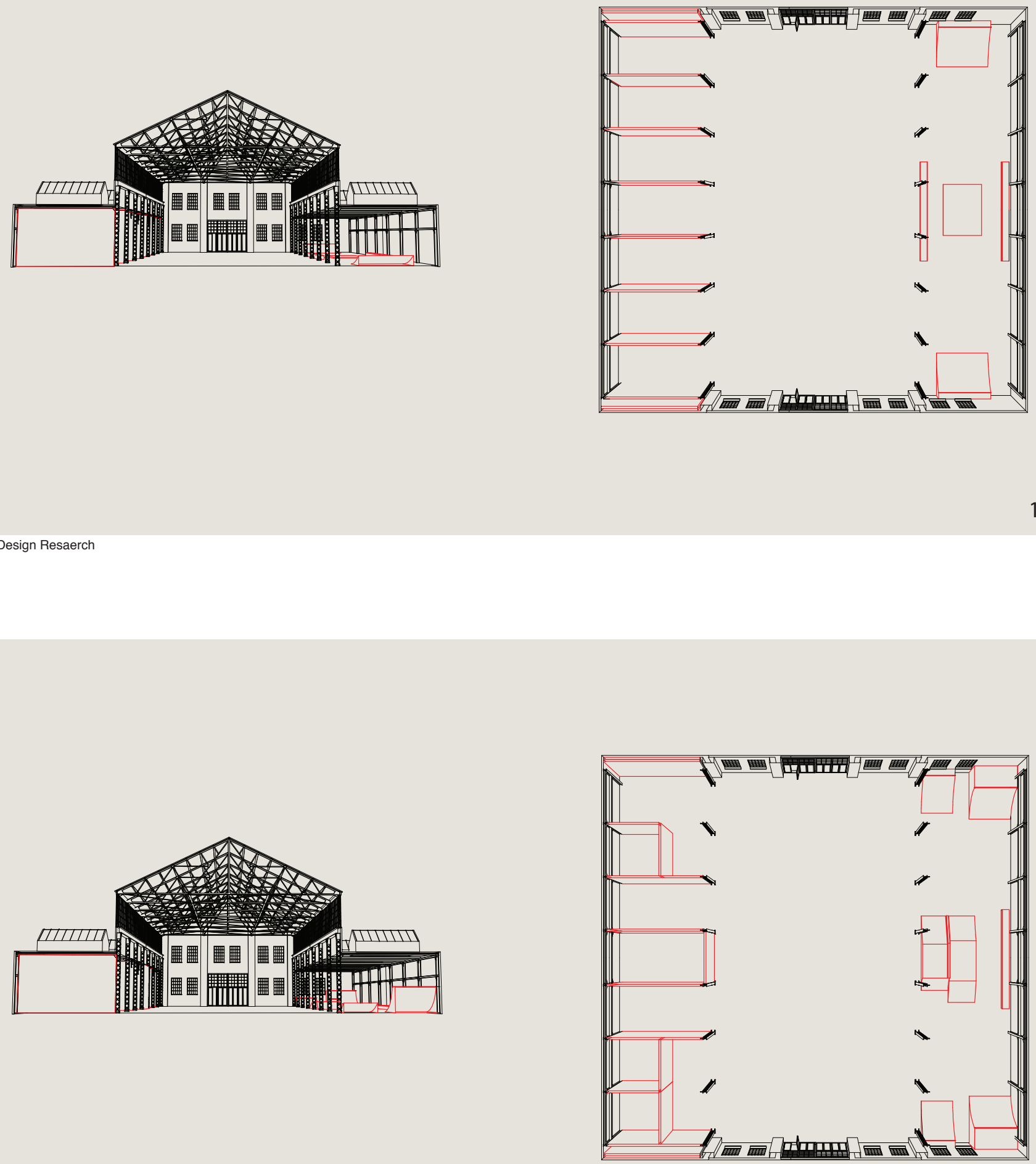

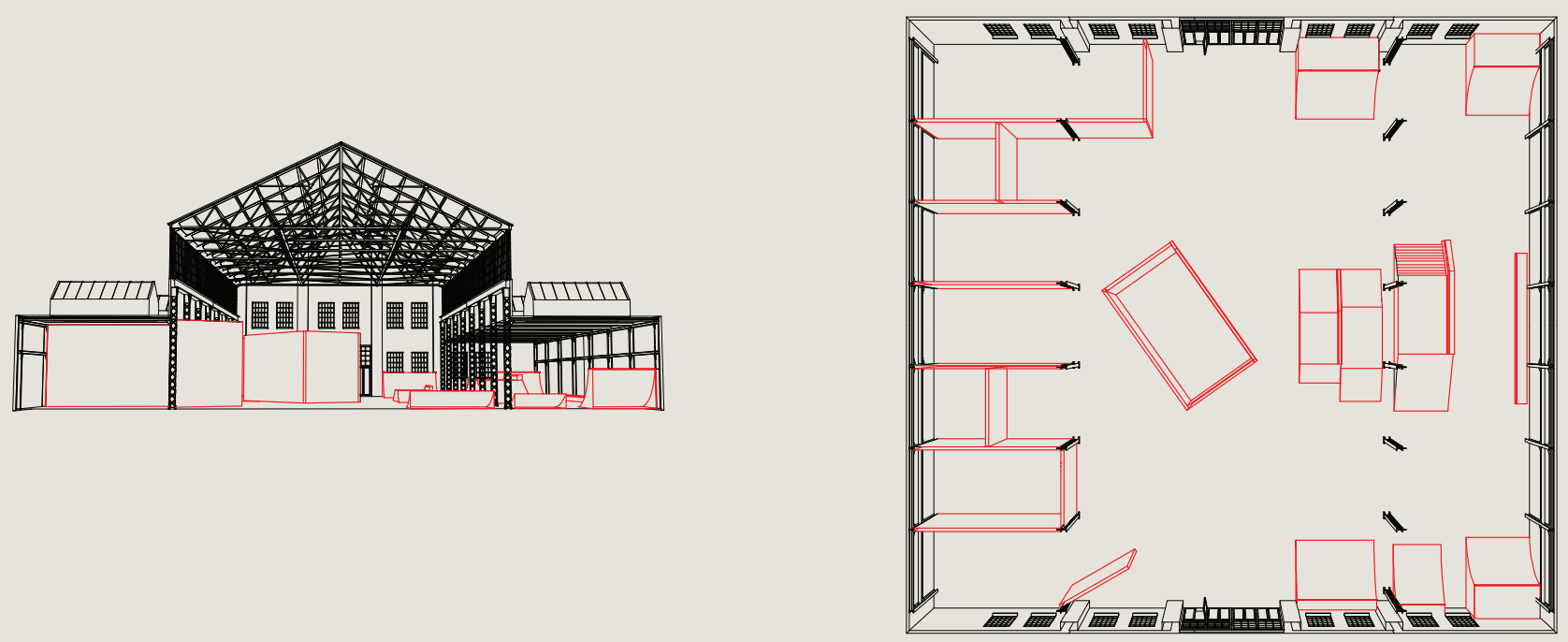

4

Fig. 8.7 Design Resaerch
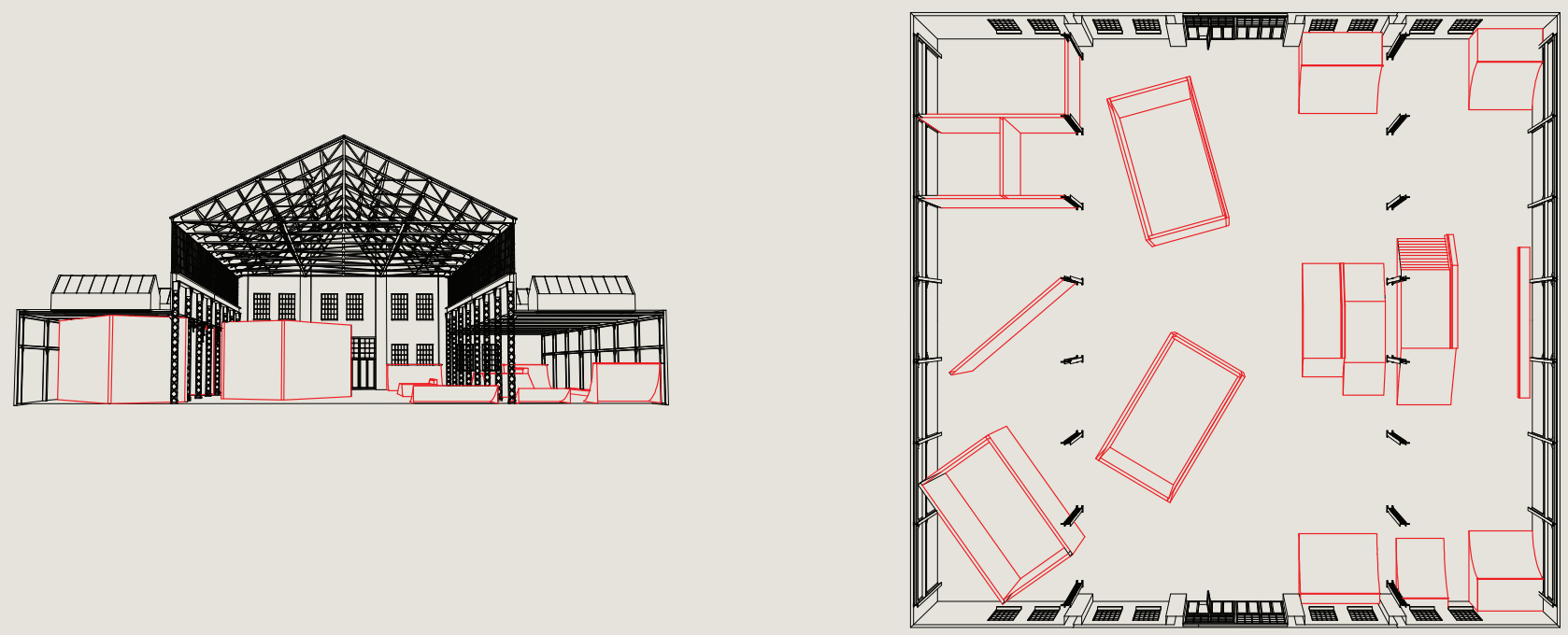


\section{Bibliography}

Alper, D. (2015). Beautiful terrible ruins. Detroit and the anxiety of decline. New Jersey: Rutgers University Press.

Aubert, D Cavar,L. Chandani, N. (2012). Thanks for the View Mr. Mies. New York: Metropolis Books.

Bacon, S. (2015). Ruinous Heterotopia - Berlin, Techno and Gentrification. (Masters Dissertation), Retrieved from: https://issuu.com/stuartbacon/docs/stuart_bacon_thesis_document_illust

Borden, lain. (2001). Skateboarding, space and the city. New York City: Berg.

Borden, I (ed.), Fraser, M. (ed.), Penner, B.(ed). (2014). Forty Ways to Think About Architecture. London: John Wiley \& Sons Ltd.

Braae, Ellen. (2015). Beauty redeemed, recycling industrial landscapes. Denmark: IKAROS Press.

Boudon, P. (1969). Lived-in architecture Le Corbusiers Pessac revisited. Cambridge: MIT Press.

Cook, Peter. (2014). Drawing the motive force of architecture. West Sussex: John Wiley and Sons Ltd.

Corbusier, L. (1927). Toward an Architecture. New York: Getty Research Institute.

Daniel M. G. Raff (1988). Wage Determination Theory and the Five-Dollar Day at Ford.

The Journal of Economic History. Vol. 48, No. 2, The Tasks of Economic History, pp. 387-399

Deamer, P. (ed.) (2015) Architecture and capitalism: 1845 - present. Abingdon: Taylor and Francis Group.

Debord, G. (1983). Society of the Spectacle. Detroit: Black and Red.

Doucet, Brian. (2017). Why Detroit matters - lessons and visions. Geography; Sheffield Vol. 102, (Summer 2017): 104-110.

Detroit Future Cities. (2018). A Detroit Future City (DFC) Implementation Office Special Report: Vacant Industrial Properties Require Innovative Reuse. (Report) Retrieved from: https://mailchi.mp/detroitfuturecity/dfc-special-report-2-vacant-industrial-properties-an-opportunity-for-innovative-adaptive-reuse 
Do Carmo, L. (2016) Resistance and compromise: spacial and aesthetic approaches of alternative cultural spaces. (Doctoral dissertation). Retrieved from: https://infoscience.epfl.ch/record/223448/files/ EPFL_TH7051.pdf

Edensor, T. (2005). Industrial ruins. space, aesthetics, and materiality. New York City: Berg.

Elliot M., Feingolds D, et al. (2013). History's future in the north end. (Journal). Retrieved from: https:// taubmancollege.umich.edu/sites/default/files/files/mup/capstones/Historys_Future_North_End.pdf

Gartman, D. (2009). From Autos to Architecture. New York: Princeton Architectural Press.

Gabrielsson, C. (ND). Squatting my mind - towards an architectural ecosophy. (Journal) Retrived from: http://field-journal.org/wp-content/uploads/2016/07/11-Squatting-my-Mind.pdf.

Gonyea, Don. (April, 2009). Detroit industry: the Murals of Diego Rivera. (Article) Retrived from: https:// www.npr.org/2009/04/22/103337403/detroit-industry-the-murals-of-diego-rivera

Herscher, A. (2012). The Unreal estate guide to Detroit. Ann Arbor: The University of Michigan Press.

Hidelbrand, Grant. (1974). Designing for industry, the architecture of Albert Kahn. Cambridge: The MIT Press.

Hebdige, D. (1979). Subculture the Meaning of Style. New York City: Routledge.

Ikenouye, T. Simon, Anita (2014). Tools and Methods of Analysis: Insulation Retrofit in Adaptive Reuse of Early 20th-Century Industrial Buildings. (Journal). Retrieved from: http://rci-online.org/wp-content/ uploads/2014-08-ikenouye.pdf

Kosec, M. (2017). Ruincarnations: The potential of ruins or the ruin of potential? in \&Beyond (ed). Archifutures volume 2 the studio. dpr-barcelona.

LeDuff, Charlie. (2013). Detroit an American autopsy. New York: The Penguin Press.

Lefebvre, H. (1974). The Production of Space. Oxford: Basil Blackwell Limited.

Miller, M. (2018). How Michigan Became the Epicenter of the Modernist Experiment. (Article). Retrieved from: https://www.nytimes.com/2018/09/06/t-magazine/michigan-modernist-architecture.html 
NA. (2010). Brief history of detroit's music scene. (Article) Retrieved from: https://detroithistorical.org/ sites/default/files/images/Brief\%20History\%20of\%20Detroits\%20Music\%20Scene.pdf

NA. (N.D.). Spirit of Detroit, the. (Article) Retrieved from: https://detroithistorical.org/learn/encyclopedia-of-detroit/spirit-detroit

Ockman, J. (2016). Rethinking the concept of an architectural avant-garde in and for the twenty-first century in O. Fischer (ed). Dialectic IV: Architecture at Service. Novato: Oro Editions.

Padnani, Amy. (2017). Anatomy of Detroit's decline. (Article) Retrieved from: https://archive.nytimes. com/www.nytimes.com/interactive/2013/08/17/us/detroit-decline.html

Pizzagalli, S. Privilieggio, N. and Schoonderbeek, M. (2013) Spaces, poetics and voids. Delft: Archintectura \& Natural Press.

Reid, D. (2018) How do we improve cities without causing displacement? Discussion from the Salzburg Global Seminar. (Article). Retrieved from: http://spacing.ca/toronto/2018/11/01/how-do-we-improvecities-without-causing-displacement-discussion-from-the-salzburg-global-seminar/

Robiglio, M. (2017). RE-USA: 20 American stories of adaptive reuse: A toolkit for post-industrial cities. Berlin: Jovis Publishing

Rosati, L. and Staniszewski, M. (2012). Alternative histories. New York art spaces 1960 to 2010. Cambridge: The MIT Press

Sadler, D. (2016). Counterpreservation. Architectural decay in Berlin since 1989. Ithaca: Cornell University Press.

Till, Jeremy. (2009) Architecture depends. Cambridge: MIT Press.

Shaw, P., Hudson, J. (2009). The Qualities of Informal Space: (Re)appropriation within the informal, interstitial spaces of the city. (Proceedings of the Conference held at the University of Brighton). Retrieved from: http://arts.brighton.ac.uk/_data/assets/pdf_file/0003/44850/41_Pamela-Shaw,Joanne.Hudson_The-Qualities-of-Informal-Space.pdf

Sheridan, D. (ND.) The space of subculture in the city: getting specific about Berlin's indeterminate territories. Retrieved from: http://field-journal.org/wp-content/uploads/2016/07/d-sheridan.pdf 
Sugrue, Thomas J. (Spring 2007). Motor city: the story of Detroit. (Article) Retrieved from: http://maillinode.gilderlehrman.org/history-by-era/politics-reform/essays/motor-city-story-detroit

Till, Jeremy. (2009) Architecture depends. Cambridge: MIT Press.

Trigg, D. (2006). The aesthetics of decay. Nothingness, nostalgia, and the absence of reason. New York: Peter Lang.

Walker, S. (2009). Gordon Matta-Clark art, architecture and the attack on modernism. New York: I.B. Taurus \& Co. Ltd 
